\title{
Provenance and tectonic significance of the Palaeoproterozoic metasedimentary successions of central and northern Madagascar
}

\author{
B. De Waele ${ }^{\mathrm{a}, \mathrm{b}, *}$, R.J. Thomas ${ }^{\mathrm{b}}$, P.H. Macey ${ }^{\mathrm{c}}$, M.S.A. Horstwood ${ }^{\mathrm{b}}$, R.D. Tucker ${ }^{\mathrm{e}}$, P.E.J. Pitfield ${ }^{\mathrm{b}}$, \\ D.I. Schofield ${ }^{b}$, K.M. Goodenough ${ }^{d}$, W. Bauer ${ }^{b}$, R.M. Key ${ }^{d}$, C.J. Potter ${ }^{e}$, R.A. Armstrong ${ }^{f}$, J.A. Miller ${ }^{g}$, \\ T. Randriamananjara ${ }^{\mathrm{h}}$, V. Ralison ${ }^{\mathrm{h}}$, J.M. Rafahatelo ${ }^{\mathrm{h}}$, M. Rabarimanana ${ }^{\mathrm{h}}$, M. Bejoma $^{\mathrm{i}}$ \\ a SRK Consulting, Level 1, 10 Richardson Street, West Perth, WA 6005, Australia \\ ${ }^{\mathrm{b}}$ British Geological Survey, Keyworth, Notts NG12 5GG, United Kingdom \\ ${ }^{\mathrm{c}}$ Council for Geoscience, Western Cape, South Africa \\ d British Geological Survey, Murchison House, Edinburgh, United Kingdom \\ e United States Geological Survey, Reston, VA 20192, USA \\ ${ }^{\mathrm{f}}$ Australian NationalUniversity, Canberra, Australia \\ g Stellenbosch University, Stellenbosch, South Africa \\ h Projet de Gouvernance des Ressources Minières, Antananarivo, Madagascar \\ ${ }^{\mathrm{i}}$ Université de Antananarivo, Antananarivo, Madagascar
}

\section{A R T I C L E I N F O}

\section{Article history:}

Received 9 July 2009

Received in revised form 19 April 2011

Accepted 26 April 2011

Available online xxx

\section{Keywords:}

$\mathrm{U}-\mathrm{Pb}$ dating

Detrital provenance

East African Orogen

Gondwana

Palaeoproterozoic

Tectonics

\begin{abstract}
A B S T R A C T
New detrital zircon $\mathrm{U}-\mathrm{Pb}$ age data obtained from various quartzite units of three spatially separated supracrustal packages in central and northern Madagascar, show that these units were deposited between 1.8 and $0.8 \mathrm{Ga}$ and have similar aged provenances. The distribution of detrital zircon ages indicates an overwhelming contribution of sources with ages between 2.5 and $1.8 \mathrm{Ga}$. Possible source rocks with an age of $2.5 \mathrm{Ga}$ are present in abundance in the crustal segments (Antananarivo, Antongil and Masora Domains) either side of a purported Neoproterozoic suture ("Betsimisaraka Suture Zone"). Recently, possible source rocks for the $1.8 \mathrm{Ga}$ age peak have been recognised in southern Madagascar. All three supracrustal successions, as well as the Archaean blocks onto which they were emplaced, are intruded by mid-Neoproterozoic magmatic suites placing a minimum age on their deposition. The similarities in detrital pattern, maximum and minimum age of deposition in the three successions, lend some support to a model in which all of Madagascar's Archaean blocks form a coherent crustal entity (the Greater Dharwar Craton), rather than an amalgamate of disparate crustal blocks brought together only during Neoproterozoic convergence. However, potential source terranes exist outside Madagascar and on either side of the Neoproterozoic sutures, so that a model including a Neoproterozoic suture in Madagascar cannot be dispelled outright.
\end{abstract}

(c) 2011 Elsevier B.V. All rights reserved.

\section{Introduction}

Madagascar occupies a critical, central position within the East African Orogen (EAO; Fig. 1). Consequently, an understanding of the geological history of its component terranes is important for constraining the palaeogeography of the entire region through time and elucidating the assembly history of Gondwana. Many recent studies of the geology of Madagascar have focused on comparisons between the three component Archaean cratonic domains and intervening paragneiss assemblages (Collins, 2006

\footnotetext{
* Corresponding author at: SRK Consulting, Level 1, 10 Richardson Street, West Perth, WA 6005, Australia.

E-mail addresses: bdewaele@srk.com.au, info@bdewaele.be (B. De Waele).
}

and references therein). However, new data have been obtained for the northern half of Madagascar through a concerted phase of geological mapping and research undertaken by teams from the British and United States Geological Surveys (BGS-USGS) and the Council for Geoscience of South Africa (CGS), in conjunction with Malagasy geologists from the Projet du Governance des Ressources Minérales (PGRM), as part of a multi-disciplinary, World Bank-sponsored project which ran between 2004 and 2008 (see BGS-USGS-GLW, 2008 and CGS, 2009a,b). This study facilitated re-interpretations of the tectonic framework of the northern half of Madagascar. In this paper we focus on a poorly understood aspect of the Precambrian shield: the age and provenance of the enigmatic metasedimentary units of Proterozoic age that rest upon the Archaean cratons of central and eastern Madagascar. 


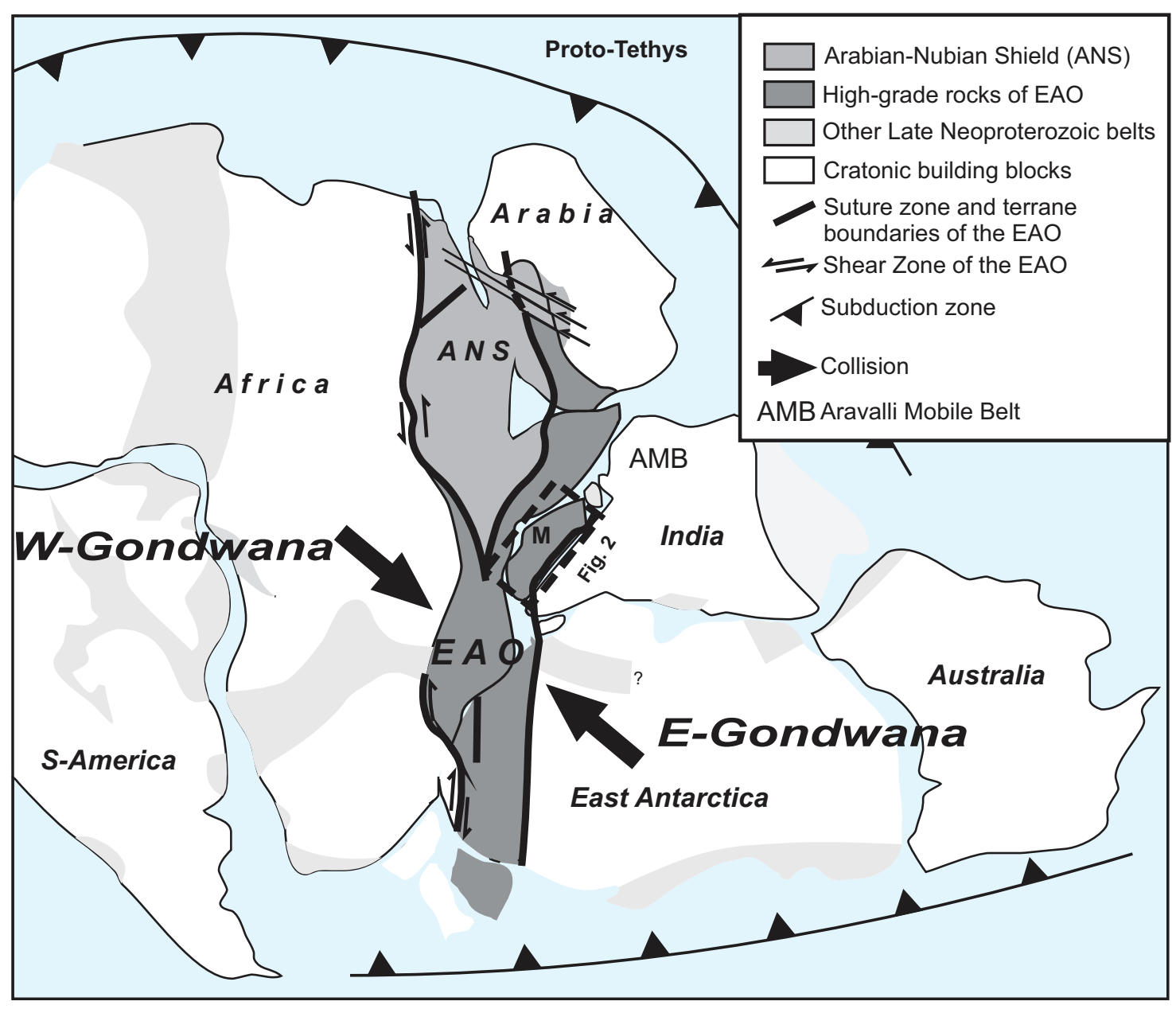

Fig. 1. Palaeoposition of Madagascar in Gondwana (after Thomas et al., 2009).

The ancient shield of Madagascar is composed of distinctive Archaean crustal blocks: the dominantly Meso- to Neoarchaean blocks of east Madagascar (Antongil and Masora cratons) and the exclusively Neoarchaean block of central Madagascar (Antananarivo Craton, Fig. 2). Two very different hypotheses attempt to explain their present-day juxtaposition. A widely-accepted hypothesis (e.g. Collins, 2006 and references therein) portrays them as disparate fragments of peninsular India and central East Africa, respectively, joined along a convergent margin boundary - the "Betsimisaraka suture" - active throughout Neoproterozoic time (ca. 800-550 Ma). The "Betsimisaraka suture" comprises a belt of Neoproterozoic metasedimentary rocks, intruded by voluminous Neoproterozoic to Cambrian granitoids, which has been named as the Anaboriana-Manampotsy belt (Fig. 2). Another hypothesis (Tucker et al., 2010a,b) portrays them as different parts of a common craton (the Greater Dharwar Craton) joined by a Neoarchaean accretion event (ca. $2.5 \mathrm{Ga}$ ). Both perspectives acknowledge that the disparate Archaean cratons are overlain by metasedimentary rocks of Proterozoic age: the eastern Antongil and Masora cratons by the Sahantaha and Maha groups respectively, and the western Antananarivo Craton by the Itremo Group (Fig. 2). The metasedimentary rocks represent either remnants of discrete sedimentary basins deposited on the Archaean cratons, and/or dissected parts of one or more parautochthonous to allochthonous sheets that were structurally emplaced during post-depositional orogenic events (e.g. De Waele et al., 2008).
Of the three successions described here, the Itremo Group, which locally overlies the western Antananarivo Craton, is the best-studied (Figs. 2, 3). It comprises a thick succession of quartzite, metapelite and metacarbonate, affected by (sub-) greenschist facies metamorphism, and has yielded detrital zircon age data with the largest modes at ca. 2500 and 1850 Ma (Cox et al., 1998, 2004a; Fitzsimons and Hulscher, 2005). On the basis of the geochronological data, carbonate $\delta^{13} \mathrm{C}$ compositions and the morphology of stromatolites in the succession, the Itremo Group is regarded as having been deposited during the Late Palaeoproterozoic (Cox et al., 1998, 2004a; Fitzsimons and Hulscher, 2005), although a younger age cannot be ruled out. As yet, bedrock of Palaeoproterozoic age (ca. $2.0-1.8 \mathrm{Ga}$ ) has only been identified in southern Madagascar (Tucker et al., 2010a). Nevertheless, a close match of detrital zircon ages from the Itremo Group with the Ubendian-Usagaran belts of east Africa (e.g. marginal to the Tanzania Craton), led Cox et al. (1998, 2004a) and Fitzsimons and Hulscher (2005) to conclude that the Antananarivo Craton was derived from East Africa. In their view, the Itremo Group was deposited unconformably on the East African margin, and a piece of it (the future Antananarivo Craton) rifted away to form a microcontinent, "Azania” (Collins and Pisarevsky, 2005). The Antananarivo Craton and overlying supracrustal rocks were then metamorphosed and deformed during an early Neoproterozoic orogenesis (ca. pre-800 Ma, Collins et al., 2003b; Collins, 2006) prior to its rifting away, and subsequent amalgamation with east Madagascar. 


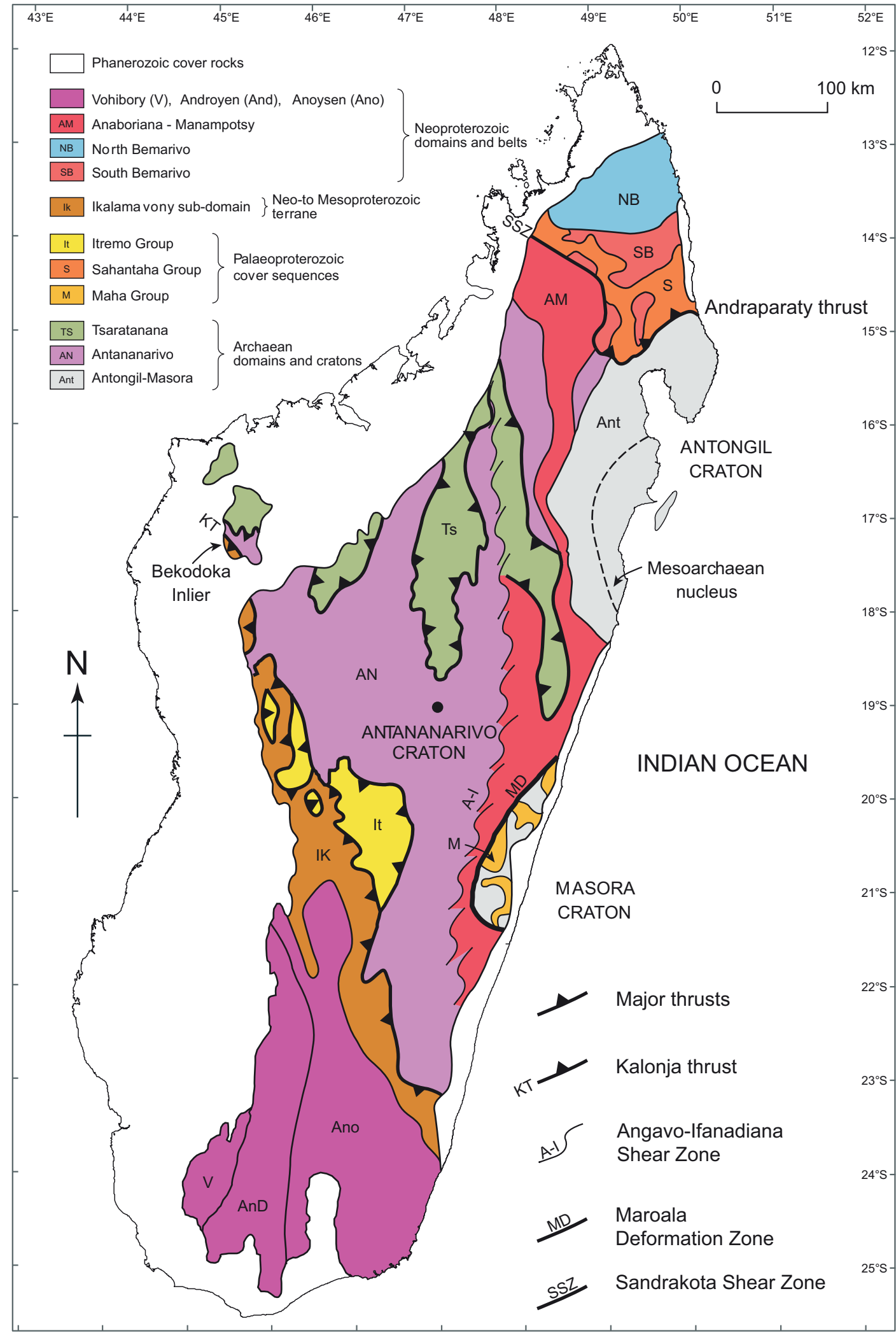

Fig. 2. Tectonic architecture of Madagascar showing the location of successions described in the text.

The less well-studied Sahantaha Group of northern Madagascar has been variably metamorphosed up to amphibolite-/granulitefacies, in contrast to the dominant greenschist metamorphism in the Itremo and Maha groups. Two samples of quartzite of the Sahan- taha Group yielded a U-Pb detrital zircon signature comparable to the Itremo Group (Cox et al., 2003).

In this paper, we compare and contrast the lithostratigraphic, metamorphic and structural characteristics of the three groups, and 


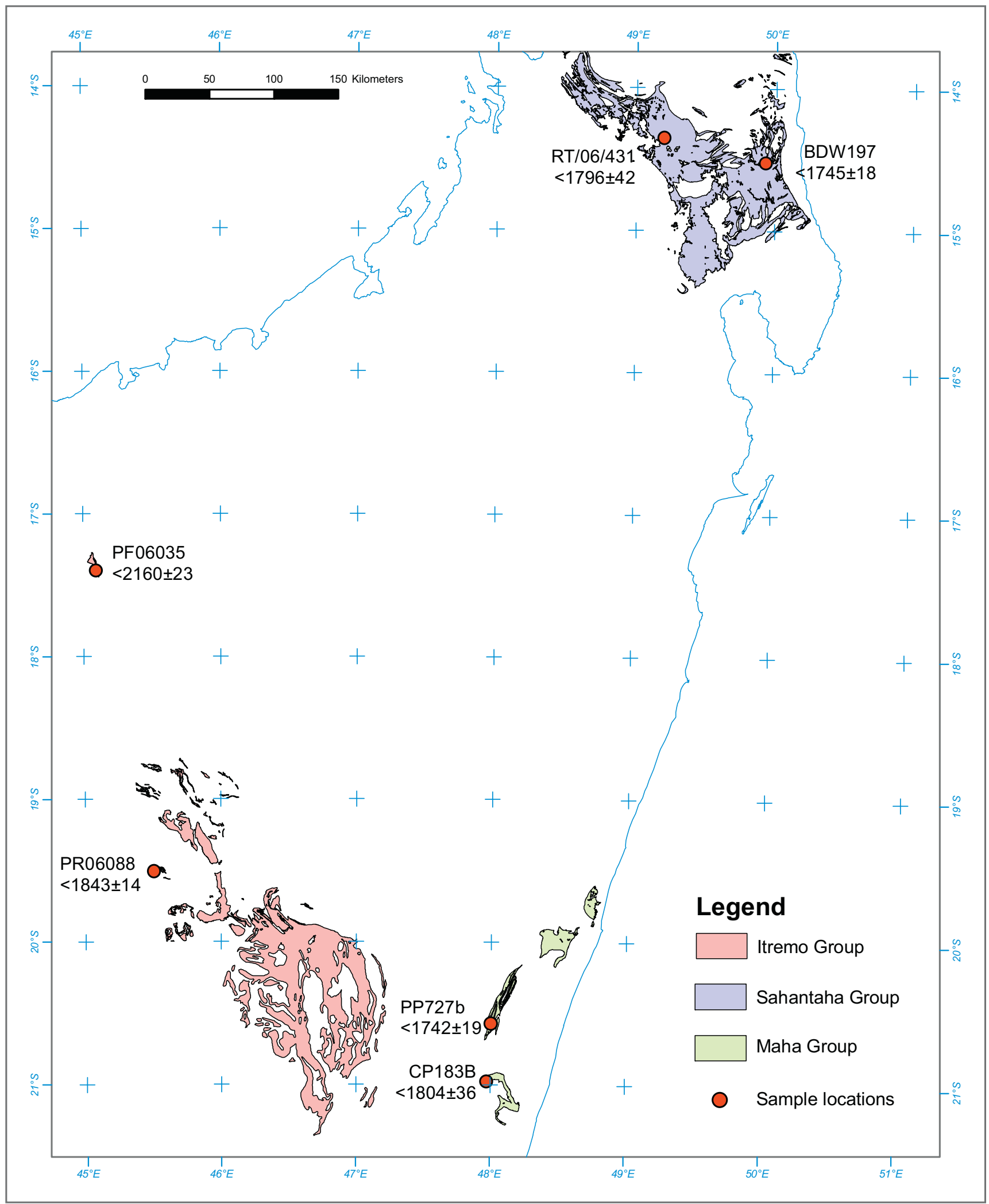

Fig. 3. Distribution of the Itremo, Sahantaha and Maha groups and location of the geochronological samples.

present further detrital zircon age data on the Itremo Group, along with new detrital age data for the Sahantaha and Maha groups, which overlie the Antongil and Masora cratons respectively. On the strength of these data, we re-examine existing models for the post-Archaean (Pan-African) tectonic development of Madagascar.

\section{Geology of the tectonic terranes}

The recent phase of $1: 100,000$ to $1: 500,000$ scale geological mapping has allowed the redefinition of the various tectonic terranes of central and northern Madagascar (BGS-USGS-GLW, 2008; 
CGS, 2009a,b, see Fig. 2), the salient features of which are briefly described below:

\subsection{Antongil Craton}

This terrane of NE Madagascar dominantly comprises of granitoids of two main ages. An older Mesoarchaean nucleus, centred on the island of Nosy Boraha (Isle de Saint Marie) is characterised by intrusive TTG gneisses and supracrustal rocks (Nosy Boraha Suite and Fenerivo Group) dated at ca. 3.32-3.18 Ga (Tucker et al., 1999, 2010a). Intrusive into these are voluminous Neoarchaean (ca. 2.54-2.50 Ga) granitoids (Masoala Suite, Tucker et al., 1999, 2010b; Paquette et al., 2003; Schofield et al., 2010) and related supracrustal rocks of the Mananara Group (Schofield et al., 2010). The Masoala Suite, which constitutes over $90 \%$ by area of the northern Antongil Craton, is composed of a wide range of migmatitic granitoid lithologies of late Neoarchaean age, with minor disrupted mafic schist and paragneiss bodies of the Mananara Group occurring as xenolithic pods, lenses and schlieren (Schofield et al., 2010). In the northern Antongil Craton, a widespread suite of metagabbro/microgabbro intrusions known as the Ankavanana Suite, as well as a minor supracrustal succession of limited extent and ascribed to the Andrarona Group have been shown to be Palaeoproterozoic in age (Schofield et al., 2010). The Antongil Craton largely escaped Neoproterozoic reworking.

\subsection{Masora Craton}

The Masora Craton comprises TTG orthogneisses of the Befody Suite (3.3-3.1 Ga; BGS-USGS-GLW, 2008; Tucker et al., 2010b), which are correlated with the Nosy Boraha Suite of the Antongil Craton. Supracrustal units form an important component of the Masora Craton and include the dominantly greenschistgrade metasedimentary and metavolcanic Maha Group, and the amphibolite-grade metamafite-paragneiss-paraschist-banded iron formation-serpentinised ultramafic pods association of the Vohilava Group. Thus the Vohilava Group has a metavolcaniclastic character (paragneiss, schist and amphibolites) and could be a possible correlative to the Meso- to Neoarchaean Mananara Group in the Antongil Craton. In general, the Masora Craton rocks show early amphibolite facies metamorphism with some late high-temperature ductile shearing and a more widespread low greenschist facies overprint.

The Masora Craton differs from the Antongil Craton by the apparent absence of Neoarchaean felsic magmatism, a greater proportion of supracrustal units and by widespread Neoproterozoic reworking. The southern and western margins of the Masora Craton are juxtaposed against the Neoproterozoic AnaborianaManampotsy Belt along the curviplanar "Maroala Deformation Zone" (MD, Fig. 2), comprising a tectonically mixed package of continental margin sedimentary rocks and Masora Craton rocks. 840-760 Ma granites-granodiorites, leucotonalites to quartz diorites and metagabbro-diorites occur throughout the Masora Craton mostly as folded sheets; ca. 630 Ma granites are localised within the MD and the adjacent Anaboriana-Manampotsy Belt (BGS-USGSGLW, 2008).

\subsection{Antananarivo Craton}

The Antananarivo Craton consists of Archaean orthogneisses (Betsiboka Suite), which record zircon $\mathrm{U}-\mathrm{Pb}$ ages of $2.5 \mathrm{Ga}$ (see for instance Kröner et al., 2000; Tucker et al., 2007 and BGSUSGS-GLW, 2008) and paragneisses (Vondrozo and Sofia groups) that were metamorphosed and partially melted under granuliteand upper amphibolite-facies conditions in Neoarchaean time (Nicollet, 1990; Goncalves et al., 2004; BGS-USGS-GLW 2008;
CGS, 2009a; Tucker et al., 2010a). The age evidence includes SHRIMP and $\mathrm{Pb}-\mathrm{Pb}$ evaporation dates obtained on deformed granulites (2747-2515 Ma, Kröner et al., 2000) and Thermal Ionisation Mass Spectrometry (TIMS) studies on four samples south of Antananarivo (2590-2503 Ma, Tucker et al., 1999). Indications for Palaeoproterozoic and Mesoproterozoic crust incorporated within the Antananarivo Craton include zircon xenocrysts retrieved from Neoproterozoic intrusions with ages from 2188 to $1007 \mathrm{Ma}$ (three between 1057 and $1007 \mathrm{Ma}$, Kröner et al., 2000), but those could also have been derived from metasedimentary rocks.

A series of structurally overlying, possibly allochthonous belts of predominantly mafic gneisses occur within the Antananarivo Craton, collectively termed the Tsaratanana Complex (Collins et al., 2003a; BGS-USGS-GLW, 2008; CGS, 2009b). These comprise, from west to east, the Ambohipaky, Maevatanana, Andriamena, and Beforona-Alaotra belts (Fig. 2). They are composed of mafic tonalitic orthogneisses and paragneiss sequences of Archaean age (Tucker et al., 1999, 2007; Goncalves et al., 2003, 2004; CGS, 2009b). Field evidence from the basal contact of the Beforona-Alaotra Belt, which overlies the mid-Neoproterozoic Anaboriana-Manampotsy Belt, suggests tectonic juxtapositioning with the underlying Antananarivo Craton, although this structural inversion could have resulted from recumbent and overturned folding.

Large volumes of magma were intruded throughout the Antananarivo Craton - Tsaratanana Complex as a result of Neoproterozoic to Cambrian orogenesis during three major episodes, the ImoronaItsindro, Kiangara and Ambalavao-Maevarano intrusive events:

(a) The Imorona-Itsindro magmatism occurred between 855 and $720 \mathrm{Ma}$ (maximum range that also includes $\mathrm{Pb}-\mathrm{Pb}$ evaporation data, Kröner et al., 2000; CGS, 2009a,b; BGS-USGS-GLW, 2008). The Imorona-Itsindro Suite comprises variably deformed syenites, gabbros (Handke et al., 1997a,b, 1999; Tucker et al., 1999, 2007; CGS, 2009a,b) and granitoids (Kröner et al., 2000; Collins et al., 2003b);

(b) The Kiangara Suite is dated at between 634 and $565 \mathrm{Ma}$ (Ashwal, 1997; Paquette and Nédélec, 1998; Kröner et al., 1999a,b, 2000; Tucker et al., 1999, 2007; Meert et al., 2001; CGS, 2009a) and comprises thick $(<0.5 \mathrm{~km})$ sill-like intrusions known in the literature as "granitoïdes stratoïdes" (Meert et al., 2003; BGSUSGS-GLW, 2008).

(c) The Ambalavao-Maevarano suites comprises largely posttectonic granitoids with an age range of 565-520 Ma (e.g. Meert et al., 2003; Goodenough et al., 2010 and references therein).

The Antananarivo Craton is juxtaposed against the Antongil and Masora cratons along a system of steeply-dipping high strain zones incorporating intercalated units of younger (Neoproterozoic) sedimentary and igneous rocks that form part of the Anaboriana-Manampotsy Belt (BGS-USGS-GLW, 2008). This belt of high-grade Neoproterozoic metasedimentary rocks and orthogneisses is broadly, but not exactly, spatially coincident with the 'Betsimisaraka Suture Zone' as proposed by Kröner et al. (2000). Previous workers suggested that the Antongil/Masora and Antananarivo cratons were separated by an oceanic tract prior to collision and the amalgamation of Gondwana (e.g. Collins et al., 2000a; Kröner et al., 2000; Collins, 2006 and references therein). In support of this contention, there are very distinct lithological and structural differences between the rock assemblages of the Antongil, Masora and Antananarivo cratons showing that they represent lithologically/rheologically discrete fragments of Archaean crust (Raharimahefa and Kusky, 2009). Other workers dispute the presence of a suture and favour a model of a contiguous Archaean "Greater Dharwar" craton (e.g. Tucker et al., 2010a,b). BGS-USGS-GLW (2008) suggest a more complex history of Neoproterozoic-Cambrian Pan-African orogenesis 
involving initial amalgamation of the Antananarivo and Masora cratons across the Anaboriana-Manampotsy Belt between about 820 and $740 \mathrm{Ma}$. Later (ca. $560 \mathrm{Ma}$ ) collision of the Antongil Craton with the amalgamated Antananarivo-Masora cratons took place across the Anaboriana Domain of the Anaboriana-Manampotsy Belt (Goodenough et al., 2010).

\subsection{Bemarivo Belt}

The Bemarivo Belt consists of juvenile magmatic arc crust (Tucker et al., 1999; Thomas et al., 2009) and associated arcvolcanosedimentary rocks that were accreted to the northern edge of Madagascar at ca. $520 \mathrm{Ma}$ (Buchwaldt and Tucker, 2001; Buchwaldt et al., 2002, 2003; Buchwaldt, 2006; Jöns et al., 2005a,b, 2006; Thomas et al., 2009). The belt is composed of two arc terranes (Thomas et al., 2009), dated at ca. $750 \mathrm{Ma}$ (Southern Bemarivo Domain) and ca. $720 \mathrm{Ma}$ (Northern Bemarivo Domain, see Fig. 2). These amalgamated arc terranes were translated southward across a composite Archaean foreland, with a postulated Palaeoproterozoic infrastructure, along an imbricate décollement system termed the Andaparaty Thrust (see Fig. 2 and Thomas et al., 2009).

The southern, structurally lower part of the Bemarivo Belt is dominated by extensive metasedimentary rocks of the Sahantaha Group. Arc-related granitoid rocks, dated at ca $750 \mathrm{Ma}$ and known as the Antsirabe North Suite, contain metasedimentary xenoliths which may be fragments of the Sahantaha Group (although this remains unproven). Intercalated metasedimentary successions in the northern Bemarivo Belt include the Betsiaka Group, limited to a narrow strip along the northwestern edge of the terrane, which gave detrital zircon ages no younger than ca. $2450 \mathrm{Ma}$ and two much younger volcano-sedimentary successions, the Milanoa and Daraina groups, directly dated at 749-720 Ma (Tucker et al., 1999) with detrital zircon ages of 770-720 Ma (Thomas et al., 2009). The Milanoa and Daraina groups have a notable lack of older detrital age components, testifying to their juvenile Neoproterozoic character.

\subsection{Itremo-Ikalamavony Domain}

The Itremo-Ikalamavony Domain (Fig. 2) is an Early Cambrian east-vergent fold-and-thrust belt comprising tectonically interleaved Proterozoic supracrustal and metaplutonic gneisses, translated eastwards with, and over, the reworked migmatitic rocks of the Antananarivo Domain (Moine, 1974; Fernandez et al., 2001, 2003; Fernandez and Schreurs, 2003; Nédélec et al., 2003; Cox et al., 2004b; Tucker et al., 2007, 2010a,b; CGS, 2009a,b; GAF-AG-BGR, 2009).

The domain is further subdivided into two sub-domains on the basis of differences in lithostratigraphy and metamorphic grade. In the east, the large nappes of the Itremo Sub-domain, or as it was formerly known the "Massif Schisto-Quartzo-Dolomitique" (SQD, Moine, 1974), are dominated by the Palaeoproterozoic greenschist and locally lower amphibolite facies metasedimentary rocks (quartzite, marble and pelite) of the Itremo Group that are intruded by, and tectonically interleaved with, mid-Neoproterozoic $(\sim 800 \mathrm{Ma})$ orthogneisses of the Imorona-Itsindro Suite (Moine, 1974; Fernandez and Schreurs, 2003; Cox et al., 2004b; Tucker et al., 2007; CGS, 2009a,b; GAF-AG-BGR, 2009).

In the west, the upper amphibolite to granulite facies rocks of the Ikalamavony Sub-domain consist of a stack of intensely deformed allochthons thrust eastward over the Itremo Subdomain (Tucker et al., 2007; GAF-AG-BGR, 2009; CGS, 2009a). The Ikalamavony Sub-domain includes a variety of Proterozoic metasedimentary units (Itremo, Ikalamavony and Molo groups) and two suites of intrusive granitoids (Dabolava and ItsindroImorona suites; Cox et al., 2004b; Tucker et al., 2007, 2010a,b; CGS, 2009a,b). The Ikalamavony Group comprises mainly metapelites, metapsammites and metavolcanic rocks. A metarhyolite from the succession has been dated at $1013 \pm 10$ Ma (CGS, 2009a; Tucker et al., 2010a,b). The Dabolava Suite intrudes the Ikalamavony Group and consists of calc-alkaline gabbroic, tonalitic and granodioritic orthogneisses that have yielded zircon ages between 1013 and 984 Ma (Rakotoarimanana, 2001; Tucker et al., 2007; CGS, 2009a). The eastern part of the Ikalamavony Sub-domain includes an important package of much younger metaclastic rocks (<630 Ma) which Cox et al. (2004a) termed the Molo Group. However, the full extent and distribution of this unit remains unclear (Cox et al., 2004b; GAF-AG-BGR, 2009; CGS, 2009a).

Strongly deformed Imorona-Itsindro Suite orthogneisses are found throughout the sub-domain whereas intercalated slices of Neoarchaean gneisses are much less common (CGS, 2009a). The age of the regional fold-and-thrust deformation is constrained by deformed orthogneisses of latest Neoproterozoic age and the clearly post-tectonic Cambrian granites of the Ambalavao Suite that intrude both sub-domains (Tucker et al., 2007; CGS, 2009a).

\section{Post-Archaean, pre-Neoproterozoic cover successions of Madagascar}

Three post-Archaean, pre-Neoproterozoic cover successions are recognised in three geographic areas in the northern half of Madagascar (Fig. 3): the Itremo, Sahantaha and Maha groups in western, northern and eastern Madagascar respectively. The following sections give an overview of the lithological and sedimentological character of these groups.

\subsection{Itremo Group}

\subsubsection{Itremo Group in the Itremo Sub-domain}

Originally named the "Série Schisto-Quartzo-Calcaire" (SQC) and "Groupe Schisto-Quartzo-Dolomitique", the main outcrops of the Itremo Group occur in the lower grade Itremo Sub-domain ("Massif Schisto-Quartzo-Dolomitique") in the eastern parts of the ItremoIkalamavony Domain (Fig. 2, Bésairie, 1964; Moine, 1966, 1974). Here, the well exposed quartzite-marble-pelite package is located in the relatively accessible southern parts of the Central Highlands and represents the best studied group of rocks in Madagascar (Emberger, 1955; Moine, 1968a,b, 1974; Cox et al., 1995, 1996, 1998, 2000, 2001, 2004a,b; Cox and Armstrong, 1997; Raoelison, 1997; Kröner et al., 2000; Fernandez et al., 2001, 2003; Collins et al., 2003a,c; Fernandez and Schreurs, 2003; Inzana et al., 2003; Nédélec et al., 2003; Fitzsimons and Hulscher, 2005; Tucker et al., 2007).

The lower intensity of the deformation and lower grade of metamorphism in the central parts of the Itremo Sub-domain has meant that sedimentary features and stratigraphic relationships are often well preserved. Fernandez et al. (2003) and Fernandez and Schreurs (2003) have measured a minimum thickness of the Itremo Group of at least $2250 \mathrm{~m}$ and demonstrate that the succession consists of, from bottom to top, quartzites, lower metapelites, lower metacarbonates and upper metapelites overlain by upper metacarbonates.

The upward-fining quartzites of the central Itremo Sub-domain are medium-grained and moderately- to well-sorted with numerous primary sedimentary structures preserved, such as planar lamination, wave ripples, current ripples and dune cross-bedding (Moine, 1967a,b, 1974; Cox et al., 1998; Fernandez et al., 2003; Fernandez and Schreurs, 2003). Thin metapelitic beds and laterally discontinuous layers of metaconglomerate occur in the upper parts of the metaquartzite units. The generally clast-supported metaconglomerates consist of quartzite cobbles set in a matrix of fine- to 

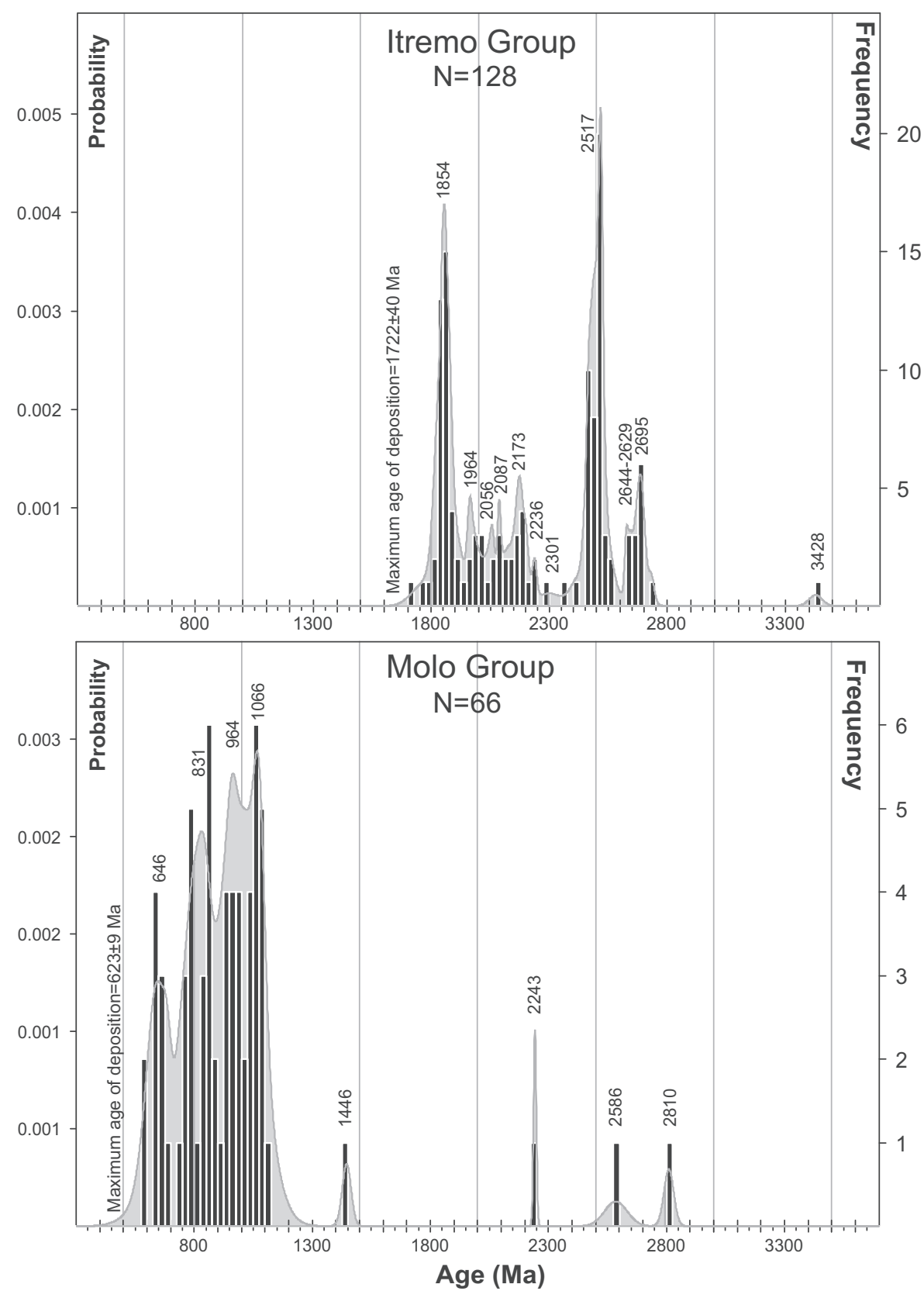

Fig. 4. Relative age-probability curves for the Itremo (top) and Molo Group (bottom). Data after Cox et al. (1998, 2004a) and Fitzsimons and Hulscher (2005).

medium-grained quartz sand (Moine, 1974; Fernandez et al., 2003; Fernandez and Schreurs, 2003; CGS, 2009a). The metapelite layers within the quartzite succession become thicker and more closely spaced upsection, and mark the transition to the overlying pelitic schist unit.

The metapelitic rocks of the central Itremo Sub-domain have traditionally been referred to as "micaschiste" by previous workers (Moine, 1968b, 1974) but Cox et al. (1998) preferred to use the general term "pelites" since these rocks consist of laminated siltstones and mudstones metamorphosed at different grades. Fine-grained quartzites with normal grading and asymmetrical hummocky cross-laminations occur as interbeds in the lower metapelite unit, whereas graphite schists occur in the upper metapelite (Fernandez and Schreurs, 2003) (Fig. 4).

The metacarbonates of the central Itremo Sub-domain are dominated by calc-silicates and dolomitic marbles that occur as lower and upper units separated by metapelite in the upper half of the
Itremo succession (Fernandez and Schreurs, 2003). Domal and pseudo-columnar stromatolites are relatively common (Fig. 5 in Cox et al., 2004a). The calc-silicates, containing variable amounts of carbonate, quartz and mica, occurring together with metamorphic tremolite and diopside, are found throughout the marbles, but are more common across the transition from metacarbonate to metapelite (Fernandez and Schreurs, 2003). Rare thin amphibolite layers are sometimes observed within the Itremo Group.

In general, most researchers agree that the Itremo Group was deposited on a shallow continental margin, but some differences remain regarding the interpretation of the detailed environmental conditions (Moine, 1967a,b, 1974; Cox et al., 1998; Fernandez et al., 2003; Fernandez and Schreurs, 2003). The most likely age of the Itremo Group is about $1.80-1.65 \mathrm{Ga}$ based on the morphology of stromatolites and the ages of the youngest detrital zircons (Cox and Armstrong, 1997; Cox et al., 1998, 2004a,b; Fernandez et al., 2003). 

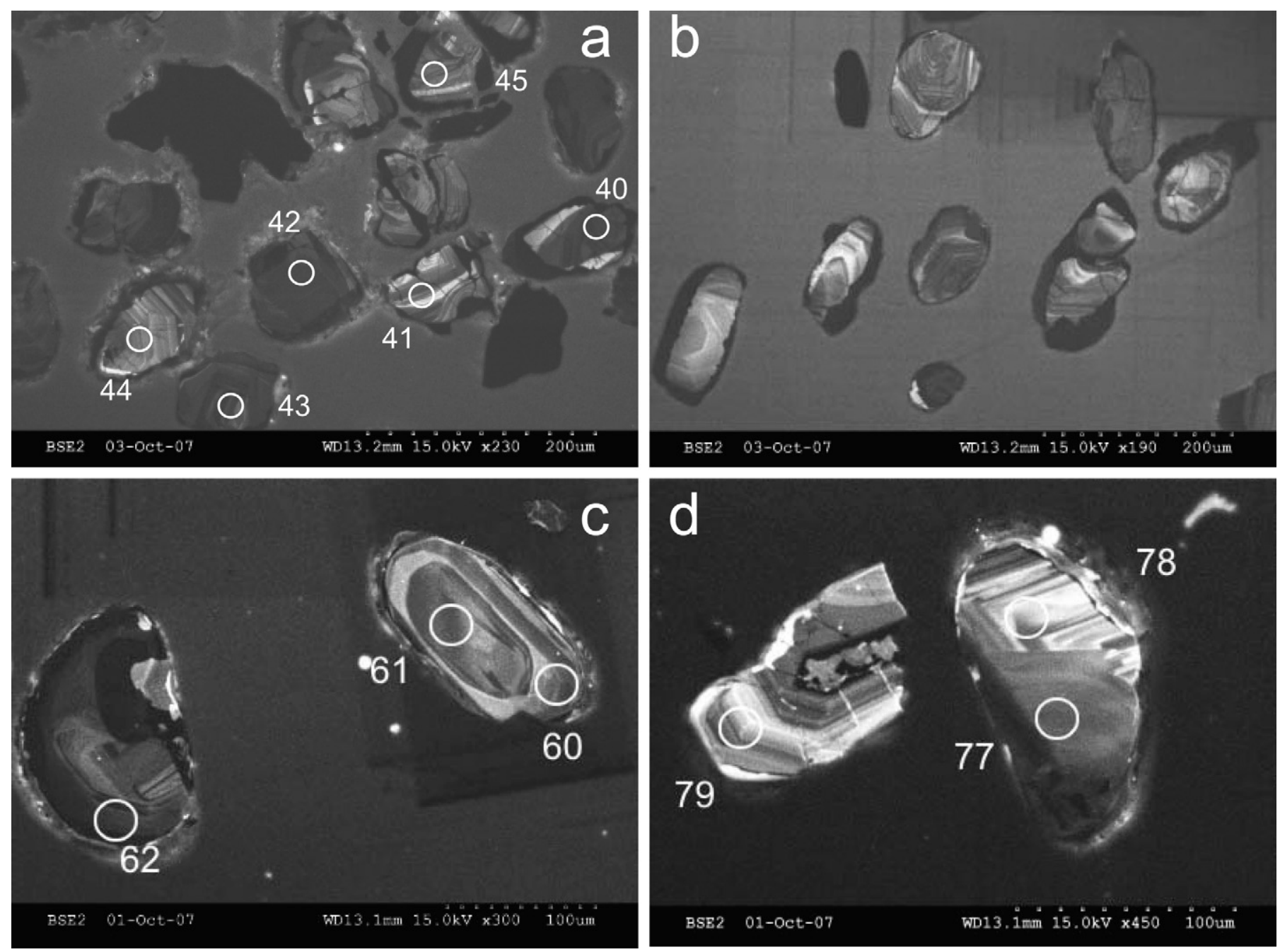

Fig. 5. Cathodo-luminescence imagery of selected zircon grains from samples of the Sahantaha Group; sample RT-06-431 (a, b) and sample BDW197 (c, d).

\subsubsection{Itremo Group in the Ikalamavony Sub-domain}

Whereas the lithostratigraphy of the Itremo Sub-domain has been relatively well understood since the publication of the 1:200,000 "Groupe Schisto-Quartzo-Dolomitique" (SQD) map of Moine (1968b), the much more intense fold and thrust deformation and the greater lithological and stratigraphic variety has led to a somewhat confusing range of different litho-tectonic subdivisions and stratigraphic nomenclature for the higher grade rocks of the Ikalamavony Sub-domain (Table 1; e.g. Fournié and Heurtebize, 1963; Moine, 1963, 1968b, 1974; Joo, 1963; Alsac, 1963a,b; Bésairie, 1964, 1969; Hottin, 1976; Windley et al., 1994; Tucker et al., 2007; Collins et al., 2000b, 2003a,b,c; Collins, 2006).

The recent CGS (2009a,b) mapping recognised three eastvergent and thrust-bounded mega-lithotectonic packages across the central and northern Ikalamavony Sub-domain (Table 1). The structurally uppermost package includes two main supracrustal rock associations: metapelite-metapsammite-amphibolitemetarhyolite and quartzite-metaconglomerate-marble. The supracrustal rocks are tectonically interleaved with orthogneisses of the Dabolava and Imorona-Itsindro suites and more rarely, thin thrust slices of Antananarivo Craton migmatites. Although these supracrustal rock associations commonly crop out separately, in places the intense infolding and thrusting results in relatively intimate and complex interfingering of the lithodemic units.

The middle lithotectonic package consists of a succession of quartzites and subordinate metaconglomerates up to $2 \mathrm{~km}$ thick that form the Bevitsika-Tsinjomay-Kingaly mountains. The lowermost lithotectonic package, which is thrust over the Itremo Sub-domain comprises mostly biotite-quartz-feldspar \pm hornblende gneisses tectonically interleaved with thick quartzitemetaconglomerate packages and large volumes of sheared Imorona-Itsindro granite orthogneiss.

Given their lithological similarities to the Itremo Group of the Itremo Sub-domain, the quartzite-metaconglomerate \pm marble associations observed in all three packages have been assigned to the Itremo Group (or SQD) by most early mappers (Table 1; Moine, 1963, 1968b; Joo, 1963; Alsac, 1963a,b) and by the CGS (2009a). The metapelite-metapsammite-amphibolite-metarhyolite association in the upper package and the biotite gneisses in the lower package are assigned to the Ikalamavony Group. Dating has revealed an additional, formerly unknown, supracrustal unit in the lower package, the Neoproterozoic Molo Group (Cox et al., 2004a), however the extent of the unit remains largely unknown (Fig. 2).

Moine $(1963,1967 a, 1974)$ considered the Ikalamavony Group rocks to be coeval distal, western facies of the Itremo Group but modern detrital zircon geochronology suggests otherwise. Detrital zircons from the thick quartzite-metaconglomerate KinangalyTsinjomay-Bevitsika mountain ridge in the central Ikalamavony Sub-domain (Fig. 2) yielded Archaean-Palaeoproterozoic age spectra and peak ages similar to those of the Itremo Group in the Itremo Sub-domain (Cox et al., 2004a, see next section) and support their classification as part of the Itremo Group. In contrast, the detrital 


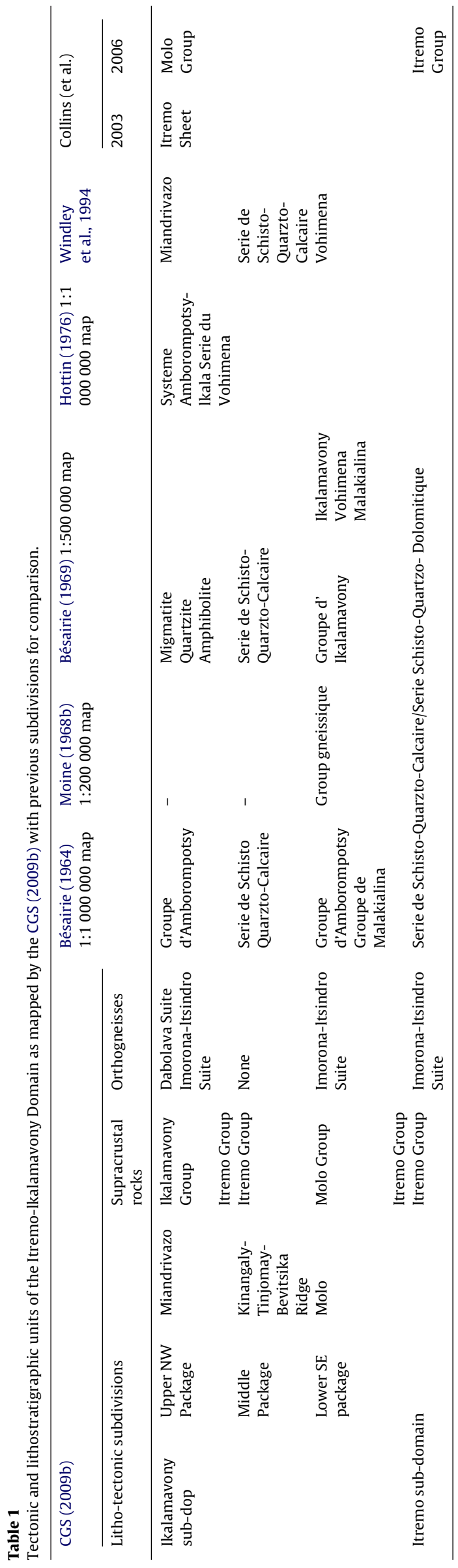

zircon from the metapelites of the Ikalamavony Group dated by the CGS (2009a) yielded a restricted range of ages between 1070 and $1020 \mathrm{Ma}$, and a metarhyolite from the unit yielded an extrusion age of $1013 \mathrm{Ma}$ (Tucker et al., 2010b). These new ages clearly demonstrate that the Itremo and Ikalamavony metasedimentary rocks were derived from different sources and cannot be coeval lateral facies equivalents. What remains unresolved is the nature of the original contact relationships between the two, often intimately related units, given that all contacts are now tectonic following the Ediacaran-Cambrian thrusting and folding. Two models are proposed. The first suggests that the Itremo and Ikalamavony were never in sedimentary contact and were only juxtaposed during Ediacaran-Cambrian orogeny. The second model proposes that the Ikalamavony Group was deposited unconformably upon the Itremo Group. Arguments against the unconformity model include: (1) the complete absence of recycled Palaeoproterozoic and older detrital zircons from the Itremo Group in the Ikalamavony Group (CGS, 2009a; Tucker et al., 2010b); (2) unpublished Nd isotope data imply that the Ikalamavony Group metavolcanics are juvenile and show little or no evidence of crustal contamination and (3) field observations suggest the Dabolava Suite intrudes only the Ikalamavony Group suggesting the Itremo and Ikalamavony groups were only juxtaposed during the late Neoproterozoic-Ediacaran Orogeny.

\subsubsection{Itremo Group in the Bekodoka Inlier}

The Bekodoka Inlier of northwest Madagascar (Fig. 2) has traditionally been subdivided into migmatitic orthogneisses of the Antananarivo Craton and metagreenstones of the Tsaratanana Complex (e.g. Bésairie, 1969) but the recent CGS (2009b) mapping has identified a small, formerly unknown, belt of amphibolite, quartzite and marble in the southwestern parts of the Bekodoka Inlier (Fig. 2). The supracrustal rocks form NW-striking, northeastvergent tight cylindrical folds that are clearly thrust over older, strongly migmatitic orthogneisses of the Antananarivo Craton along the Kalonja Thrust (KT on Fig. 2, CGS, 2009b). The field appearance, mineralogy and geochemistry of the rock types, the observed rock type associations and the structural and metamorphic characteristics of the belt are strikingly similar to the Itremo and Ikalamavony Group rocks further east in the central Ikalamavony Sub-domain and, along with the new detrital age data presented in this paper, the CGS (2009b) have used these similarities to classify the rocks as the north-westernmost extent of the Itremo-Ikalamavony Domain.

\subsection{Sahantaha Group}

The rocks we term the Sahantaha Group have been the subject of considerable debate for the pioneering French workers in Madagascar. Based on the mapping by Dormois (1949) and Brenon (1951), the lowermost metasedimentary gneisses of northern Madagascar, lying on Archaean basement, were ascribed to the "Système de Graphite", including amphibolite, calc-silicate and quartzite of the "Série du Sambirano" of Bésairie (1959). The rocks (quartzites, migmatites and schists, "granitised" at the base) were later called the "Serie de Sahantaha" (Bousteyak, 1970, 1972, 1974; Bousteyak et al., 1970-72). Jourde et al. (1978) equated the "Daraina-Milanoa Series" of farther north to the "Système Supérieure de Andriamena Sahantaha". This implied that the Sahantaha and Daraina-Milanoa rocks were possibly lateral equivalents, though this has been shown to be incorrect, in that the Daraina-Milanoa groups are Neoproterozoic in age, and are thus part of the northern Bemarivo Belt (Thomas et al., 2009).

The current phase of mapping has shown that the Sahantaha Group comprises a complex succession of high-grade (upper amphibolite to granulite facies), predominantly metasedimentary gneisses and schists which underlie much of the southern part 
of the Bemarivo Belt (Fig. 2). The northern part of the southern Bemarivo Domain is dominated by granitoid orthogneisses of the Antsirabe North Suite, the oldest of which is dated at ca. $758 \pm 5$ Ma (Thomas et al., 2009). The plutonic rocks locally contain xenoliths of metasedimentary gneisses which are possible correlates of the Sahantaha Group. This is uncertain, but may provide a minimum age for deposition of the group. In the southwest, the Sahantaha Group abuts the high-grade Neoproterozoic Anaboriana-Manampotsy Belt and a short segment of the Antananarivo Craton along the high-angle Sandrakota Shear Zone (SSZ on Fig. 2). In the southeast the rocks are juxtaposed with the Antongil Craton along the Andaparaty thrust (Fig. 2).

The Sahantaha Group has been subdivided into a number of lithodemic units, dominated by high-grade paragneisses and schists. These are locally rhythmically interlayered with thin metapsammite layers ranging up to $1.5 \mathrm{~m}$ thick. Quartzites are commonly developed, especially in the south near the craton margins, where they can be up to $300 \mathrm{~m}$ thick, and often form marked topographic scarp features at the base of the sequence. Individual quartzite units rapidly pass laterally into enveloping pelitic schists, defining narrow corridors. This relationship is reminiscent of coarse clastic fans or lobes passing out into mud dominated shelf or slope apron deposits and probably reflects the origin of the quartzite as a proximal continental margin sedimentary succession, originally deposited along the northern margin of a craton. In this, units of quartzite are generally gently inclined northwards and overlie the Archaean basement with a low-angled contact, and form a sequence of piggy-backed imbricate structures along a flat-lying basal décollement. In the central parts of the southern Bemarivo Belt, massive to layered pure quartzite units form striking white outcrops where they are well-layered and up to several hundred metres thick.

Calcareous and calcic metasedimentary rocks are a widely distributed and a characteristic feature of the Sahantaha Group, though they are only volumetrically significant in the south, near the margin with the Antongil Craton. In this area massive calcsilicate units crop out, lying structurally above the basal quartzite units.

The only mafic rocks within the Sahantaha Group are layers, pods and lenses of amphibolite. These are quite heterogeneous, ranging from massive to foliated, dark-grey, coarse-grained hornblende-plagioclase rocks to finer-grained laminated biotite amphibolites, often with conspicuous garnet.

\subsection{Maha Group}

Metasedimentary rocks of the Maha Group overlie the Archaean rocks of the Masora Domain and are overthrust by, and locally tectonically intercalated with, the Neoproterozoic Manampotsy Complex (part of the Anaboriana - Manampotsy Belt) along its western margin (Fig. 2). Intrusive bodies of the $820-760 \mathrm{Ma}$ Imorona-Itsindro Suite are emplaced in, and deformed with, both the Maha Group and Manampotsy Complex.

The Maha Group was first distinguished and described on the Ifanadiana-Mananjary 1:200,000-scale geological map (de la Roche, 1951, 1953). Bertucat et al. (1958) found it impossible to map the Maha and Vohilava groups separately, so a combined VohilavaMaha series was shown on the 1:100,000-scale geological map of Sheet QR52. The division was reinstated in the 1:500,000-scale compilation map of Bésairie (1970) and is supported by the recent mapping (BGS-USGS-GLW, 2008).

The most extensive outcrop of the Maha Group, the Nosivolo Formation, overlies the northern part of the Masora Craton and can be traced southwestwards into the Maroala Deformation Zone. In the north, the group comprises a medium- to low-grade siliciclastic association of interlayered pelitic and chlorite/talc schists with subordinate feldspathic schists, quartzites and amphibolites. The pelitic schists are characterised by the presence of muscovite, biotite, garnet and/or kyanite.

In the MDZ the Maha Group is represented by garnetbiotite \pm kyanite schists and paragneisses with units of locally garnetiferous quartzite, amphibolite and amphibolitised metagabbro, indicating metamorphism at higher pressures within the MDZ than further northeast on the Masora Craton. Thus, metamorphic conditions of $647^{\circ} \mathrm{C}$ and $5.6 \mathrm{~kb}$ were calculated for the Nosivolo Formation in the north, and temperatures in the range $583-640^{\circ} \mathrm{C}$ at a calculated $6.9 \mathrm{~kb}$ from a metapelite in the MDZ based on Grt-Bi geothermometer and GASP geobarometry respectively (BGS-USGSGLW, 2008).

Within the southern half of the Masora Craton, the Maha Group appears to be locally preserved in synforms and thrust slices within the Archaean basement.The relationship with the greenstone association of the Vohilava Group is, however, complex and difficult to resolve. The Maha Group in this sector is typified by the same lithological association as in the north, but appears to be dominated by quartzites and quartzo-feldspathic gneisses with pelitic schist interlayers. Regular repetition of massive-bedded, upward-fining psammitic layers and locally graphitic mica schist are reminiscent of turbiditic sequences. Calcareous rocks are not recorded from the Maha Group, in contrast to the Itremo and Sahantaha groups.

\section{Previous detrital age data from the cover sequences}

Detrital zircon age data for the cover successions, reported prior to this study, are limited to the Itremo and Molo groups of western Madagascar (Fig. 4, data after Cox et al., 1995, 1996, 1998, 2000, 2001, 2004a,b; Cox and Armstrong, 1997; Fitzsimons and Hulscher, 2005), and a single sample of quartzite in the Sahantaha Group of northern Madagascar (Cox et al., 2003). These studies show that the detrital source of the Itremo Group ranges in age from 3425 to about $1700 \mathrm{Ma}$ (Cox and Armstrong, 1997; Fernandez et al., 2003; Cox et al., 2004a,b). The detrital zircon age patterns are remarkably consistent between samples, with major peaks at approximately 2500 and $1850 \mathrm{Ma}$ and minor peaks at 2700,2250,2100 and $2000 \mathrm{Ma}$ (see summary of data in Fitzsimons and Hulscher, 2005). The maximum age of the Itremo Group was constrained by the youngest detrital monazite $(1685 \pm 29$ and $1637 \pm 29 \mathrm{Ma}$; Huber, 2000; Fernandez et al., 2003) and zircon grains (1722 $\pm 40 \mathrm{Ma}$; Cox et al., 2004a). The minimum age was constrained by the ca. $800 \mathrm{Ma}$ Imorona-Itsindro Suite orthogneisses that intrude the group (Handke et al., 1999; Kröner et al., 1999a,b; Tucker et al., 2007). A similar succession from the Molo Group yielded a youngest detrital zircon age of around $623 \mathrm{Ma}$, and was interpreted as having been deposited between that time and around $523 \mathrm{Ma}$, the age of metamorphic rims (Cox et al., 2004a). Cox et al. (2003) also reported limited data on the Sahantaha Group, which showed detrital zircon ages concentrated at $1834 \pm 4 \mathrm{Ma}$ and $2502 \pm 8 \mathrm{Ma}$, suggesting some similarity to the detrital patterns of the Itremo Group.

Although the contacts are strongly tectonised, it has been suggested that the Itremo Group was deposited unconformably onto the Archaean migmatitic gneisses of the Antananarivo Craton of central Madagascar (Cox et al., 1998). Evidence for this includes (1) the observation that the detrital zircons from the Itremo Group show age peaks at ca. 2700, 2500 and $2450 \mathrm{Ma}$ (major peaks), broadly equivalent to the main inheritance, crystallisation and migmatisation ages collected from the migmatitic gneisses of the Antananarivo Craton (Kröner et al., 1999a,b, 2000; Kröner, 2001; Fernandez et al., 2003; Fernandez and Schreurs, 2003; Cox et al., 2004a; Tucker et al., 2007; CGS, 2009b); and (2) field evidence showing that localised metaconglomerate units are proximal to, and in a few cases directly overlie basement gneisses (Cox et al., 
Table 2

Characteristics of zircon analysed from the samples in this study.

\begin{tabular}{|c|c|c|c|c|c|c|}
\hline Sample & Colour & Size (urn) & Aspect ratio & Morphology & Internal zoning & Interpretation \\
\hline RT-06-431 & Colourless, clear & $50-200$ & $1: 1-2: 1$ & $\begin{array}{l}\text { Subhedral to euhedral, pitted } \\
\text { surfaces and rounding }\end{array}$ & $\begin{array}{l}\text { Concentric zoning, some have a } \\
\text { narrow dark-CL rim }\end{array}$ & $\begin{array}{l}\text { Detrital grains from } \\
\text { dominant magmatic sources }\end{array}$ \\
\hline BDW197 & Colourless, clear & $50-150$ & $1: 1-2: 1$ & $\begin{array}{l}\text { Subhedral to euhedral, pitted } \\
\text { surfaces and rounding }\end{array}$ & $\begin{array}{l}\text { Concentric zoning, some have a } \\
\text { narrow dark-CL rim }\end{array}$ & $\begin{array}{l}\text { Detrital grains from } \\
\text { dominant magmatic sources }\end{array}$ \\
\hline CP183b & Colourless, clear & $50-200$ & $1: 1-3: 1$ & $\begin{array}{l}\text { Subhedral to euhedral, pitted } \\
\text { surfaces and variable rounding }\end{array}$ & $\begin{array}{l}\text { Concentric zoning, some complex } \\
\text { grains with core and rim domains. } \\
\text { Rims are narrow and dark-CL }\end{array}$ & $\begin{array}{l}\text { Detrital grains from } \\
\text { dominant magmatic sources }\end{array}$ \\
\hline PP727 & Colourless, clear & $50-200$ & $1: 1-3: 1$ & $\begin{array}{l}\text { Subhedral to euhedral, pitted } \\
\text { surfaces and rounding }\end{array}$ & $\begin{array}{l}\text { Concentric zoning, some complex } \\
\text { grains with core and rim domains. } \\
\text { Rims are narrow and dark-CL }\end{array}$ & $\begin{array}{l}\text { Detrital grains from } \\
\text { dominant magmatic sources }\end{array}$ \\
\hline PF06035 & Colourless, to dark brown & $50-250$ & $1: 1-3: 1$ & $\begin{array}{l}\text { Subhedral, pitted surfaces and } \\
\text { rounding }\end{array}$ & $\begin{array}{l}\text { Concentric and broad zoning. Some } \\
\text { broad and dark-CL rims }\end{array}$ & $\begin{array}{l}\text { Detrital grains from } \\
\text { dominant magmatic sources }\end{array}$ \\
\hline PR06088 & $\begin{array}{l}\text { Colourless, brown, mainly } \\
\text { slightly turbid }\end{array}$ & $100-200$ & $1: 1-2: 1$ & $\begin{array}{l}\text { Subhedral to anhedral, pitted } \\
\text { surfaces and rounding }\end{array}$ & $\begin{array}{l}\text { Concentric zoning, some have a } \\
\text { narrow dark-CL rim }\end{array}$ & $\begin{array}{l}\text { Detrital grains from } \\
\text { dominant magmatic sources }\end{array}$ \\
\hline
\end{tabular}

1998). Both the Itremo Group and the Antananarivo basement are intruded by mid-Neoproterozoic (ca. $800 \mathrm{Ma}$ ) orthogneisses of the Imorona-Itsindro Suite (Handke et al., 1999; Tucker et al., 1999, 2007; Kröner et al., 2000) indicating that the unconformity must predate these intrusions. The detrital zircon provenance analysis of the Itremo Group completed by Cox et al. (2004a) recognised several zircon age peaks that indicate that the Itremo Group was derived from local sources (Antananarivo Craton) and rocks in East Africa, and that the Antananarivo Craton might therefore have been adjacent to the Congo/Tanzania/Bangweulu Block in the Late Palaeoproterozoic/Early Mesoproterozoic. They also concluded that the detrital zircon and sedimentological similarities between rocks of the Itremo Group and the Zambian Muva Supergroup suggest a possible lithostratigraphic correlation between the two (Cox et al., 2004a).

\subsection{New Detrital zircon $U-P b$ geochronology}

Two samples from each of the Sahantaha, Maha and Itremo Groups were processed to separate detrital zircons for provenance analysis. Samples from the former two groups were analysed by laser ablation multi-collector-ICP-MS (LA-MC-ICP-MS) at the NERC Isotope Geosciences Laboratory, British Geological Survey, UK, whilst the samples from the Itremo Group were analysed using sensitive high resolution ion microprobe (SHRIMP) at the Research School of Earth Sciences, Australian National University, Canberra, Australia. Full details of the techniques and validation results are available in the methodology section in the online repository. Final data were plotted and data point ages determined using Isoplot (Ludwig, 2003) with statistics and combined probability density distributions (PDDs) and histograms produced using the "Age Display' macro of Sircombe (2004) for Microsoft Excel. Histogram bin widths were selected to reflect the total uncertainty distribution of the data points and to maximise the histogram efficiency whilst providing the best coincidence of histogram and PDD peak profiles.

\subsection{Sahantaha Group}

Detrital zircons from two samples of Sahantaha quartzite were analysed by LA-MC-ICP-MS. Sample RT-06-431 (see sample position Fig. 3) was collected from an outcrop of clean, medium- to coarse-grained, bedded quartzite. 103 analyses were conducted on zircon domains that show prominent concentric internal zoning patterns (Tables 2 and 3, Fig. 5a and b). Of these, 42 analyses plot $100 \pm 5 \%$ concordant, with remaining analyses defining crude arrays below the concordia line on a Wetherill plot (see Fig. 6a and Table 3), indicating variable amounts of non-zero Pb-loss. Assessment of ${ }^{207} \mathrm{~Pb} /{ }^{206} \mathrm{~Pb}$ data within $5 \%$ of concordance indicates a mean uncertainty of the data point ages of $14.6 \mathrm{Ma}(2 \sigma)$ and a histogram bin width efficiency of $81.4 \%$ (at 30 Ma bin width). Considering this mean age uncertainty and rounding to the nearest $10 \mathrm{Ma}$, the probability density distribution indicates age maxima at: $3190,3170,2880,2690,2440,2290,2240,2080,1910,1860,1850$, 1830 and $1800 \mathrm{Ma}$. Maxima within uncertainty define age ranges of 3190-3170 and $1860-1800 \mathrm{Ma}$ (see Fig. 6b), of which the latter is by far the largest grouping with 32 of the 42 concordant data points. The youngest concordant zircon in this dominant population has a ${ }^{207} \mathrm{~Pb} /{ }^{206} \mathrm{~Pb}$ age of $1771 \pm 18 \mathrm{Ma}(2 \sigma)$, which is interpreted as the maximum age of deposition of the quartzite.

Sample BDW197 (see sample position on Fig. 3) was collected from a large outcrop of sillimanite-bearing quartzite in the Sahantaha Group. The zircon grains show very similar morphologies and internal zoning patterns to those from sample RT-06-431, with variable sedimentary rounding and internal concentric zoning (Table 2, Fig. 5c and d). 49 analyses plot on or within $100 \pm 5 \%$ of concordia, whilst the remainder plot variably discordant along non-zero Pb-loss trends (Table 4, Fig. 6c). Assessment of ${ }^{207} \mathrm{~Pb} /{ }^{206} \mathrm{~Pb}$ ages of concordant $(>95 \%$ ) data indicates a mean uncertainty of the data point ages of $18.2 \mathrm{Ma}(2 \sigma)$ and a histogram bin width efficiency of $83.3 \%$ (at $40 \mathrm{Ma}$ bin width). The probability density distribution indicates age maxima at: 2620, 2500, 2470, 2310, 2260, 2240, 2180, $2100,2070,2040,1921,1820$ and $1760 \mathrm{Ma}$ (Fig. 6d) rounded to the nearest $10 \mathrm{Ma}$. Maxima within uncertainty define age ranges of 2500-2470, 2260-2240 and 2100-2040 Ma. By far the largest mode is that at $1820 \mathrm{Ma}$ which comprises 22 of the 49 concordant data points. The youngest detrital zircon with an age of $1745 \pm 18 \mathrm{Ma}$ provides the maximum age of deposition for this quartzite of the Sahantaha Group, agreeing within uncertainty with that for sample RT-06-431.

\subsection{Maha Group}

Two samples were analysed from the Maha Group on the Masora Domain. Sample CP183b was collected from a quartzite that forms part of a succession of quartzite, metapelite and minor metaconglomerate. 82 analyses were conducted by LA-MC-ICP-MS on both single sector zircon and core-rim domains of complex zircon grains (Tables 2 and 5, Fig. 7a and b). The data range from concordant to strongly discordant, with 47 analyses plotting within $5 \%$ of concordia (Table 5 , Fig. 8 a). $U$ content is in the range 53-1337 ppm, with the highest contents recorded in sectors interpreted as an igneous phase. Analyses on high uranium overgrowths have $U$ contents of between 221 and $951 \mathrm{ppm}$, but inspection of $\mathrm{CL}$ imagery shows that due to the relatively small size of these zones $(\sim 20 \mu \mathrm{m})$ the laser spot in all but one case (analysis 77, see Fig. 7a) possibly intersects both core and rim phases, lending some doubt to the interpretation of these analyses. Assessment of "concordant' ( $>95 \%)$ data indicates a mean 
Table 3

Zircon U-Pb LA-MC-ICP-MS data for sample RT-06-431.

\begin{tabular}{|c|c|c|c|c|c|c|c|c|c|c|c|c|c|c|}
\hline Spot & ${ }^{204} \mathrm{~Pb}$ (cps) & ${ }^{206} \mathrm{~Pb}(\mathrm{mV})$ & ${ }^{238} \mathrm{U}(\mathrm{mV})$ & $\mathrm{Pb}(\mathrm{ppm})$ & $\mathrm{U}(\mathrm{ppm})$ & ${ }^{238} \mathrm{U} /{ }^{206} \mathrm{pb}$ & $1 s \%$ & ${ }^{207} \mathrm{pb} /{ }^{206} \mathrm{pb}$ & $1 s \%$ & ${ }^{207} \mathrm{pb} /{ }^{206} \mathrm{pb}$ & $2 \mathrm{~s}$ abs & ${ }^{206} \mathrm{~Pb} /{ }^{238} \mathrm{U}$ & $2 \mathrm{~s}$ abs & $\% \mathrm{C}$ \\
\hline 15 & - & 7 & 20 & 96 & 219 & 2.279 & 1.9 & 0.2046 & 0.50 & 2864 & 16 & 2345 & 74 & 82 \\
\hline 16 & - & 12 & 32 & 166 & 349 & 2.065 & 1.9 & 0.2005 & 0.50 & 2830 & 16 & 2546 & 80 & 90 \\
\hline 17 & 445 & 11 & 48 & 153 & 528 & 3.295 & 3.0 & 0.1546 & 1.17 & 2398 & 40 & 1709 & 90 & 71 \\
\hline 18 & - & 8 & 45 & 105 & 492 & 4.302 & 4.2 & 0.1014 & 1.49 & 1650 & 55 & 1347 & 102 & 82 \\
\hline 19 & - & 4 & 30 & 60 & 331 & 4.895 & 4.6 & 0.0928 & 1.43 & 1484 & 54 & 1198 & 99 & 81 \\
\hline 20 & - & 8 & 38 & 116 & 413 & 3.520 & 2.2 & 0.1087 & 0.50 & 1777 & 18 & 1612 & 63 & 91 \\
\hline 21 & - & 4 & 13 & 61 & 148 & 2.388 & 2.0 & 0.1448 & 0.50 & 2285 & 17 & 2255 & 76 & 99 \\
\hline 22 & - & 5 & 20 & 68 & 219 & 3.187 & 2.0 & 0.1099 & 0.50 & 1798 & 18 & 1759 & 62 & 98 \\
\hline 23 & - & 8 & 46 & 118 & 503 & 4.183 & 2.0 & 0.1042 & 0.50 & 1701 & 18 & 1382 & 51 & 81 \\
\hline 24 & - & 3 & 12 & 43 & 128 & 2.948 & 1.9 & 0.1122 & 0.50 & 1836 & 18 & 1883 & 62 & 103 \\
\hline 25 & - & 12 & 97 & 168 & 1062 & 6.121 & 2.9 & 0.0936 & 1.07 & 1500 & 41 & 975 & 53 & 65 \\
\hline 26 & - & 3 & 11 & 48 & 118 & 2.391 & 1.9 & 0.1407 & 0.50 & 2236 & 17 & 2252 & 71 & 101 \\
\hline 27 & - & 4 & 14 & 57 & 152 & 2.582 & 1.9 & 0.1286 & 0.50 & 2078 & 18 & 2110 & 69 & 102 \\
\hline 28 & - & 8 & 68 & 116 & 744 & 6.209 & 2.0 & 0.0970 & 0.50 & 1566 & 19 & 963 & 36 & 61 \\
\hline 29 & - & 10 & 72 & 134 & 786 & 5.727 & 2.0 & 0.0956 & 0.50 & 1540 & 19 & 1037 & 37 & 67 \\
\hline 30 & - & 7 & 30 & 104 & 325 & 3.032 & 2.0 & 0.1130 & 0.50 & 1848 & 18 & 1838 & 64 & 99 \\
\hline 31 & - & 2 & 10 & 33 & 105 & 3.050 & 2.0 & 0.1125 & 0.50 & 1840 & 18 & 1828 & 62 & 99 \\
\hline 32 & - & 4 & 16 & 56 & 176 & 3.069 & 2.0 & 0.1128 & 0.50 & 1845 & 18 & 1818 & 63 & 99 \\
\hline 33 & - & 6 & 36 & 91 & 390 & 4.158 & 2.0 & 0.1048 & 0.50 & 1711 & 18 & 1389 & 51 & 81 \\
\hline 34 & - & 4 & 16 & 54 & 172 & 3.116 & 1.9 & 0.1141 & 0.50 & 1866 & 18 & 1794 & 59 & 96 \\
\hline 35 & - & 11 & 42 & 148 & 458 & 3.037 & 1.9 & 0.1117 & 0.50 & 1827 & 18 & 1835 & 61 & 100 \\
\hline 36 & - & 5 & 30 & 71 & 327 & 4.003 & 4.4 & 0.1024 & 1.39 & 1668 & 51 & 1438 & 113 & 86 \\
\hline 37 & - & 5 & 21 & 74 & 235 & 3.061 & 1.9 & 0.1111 & 0.50 & 1818 & 18 & 1822 & 59 & 100 \\
\hline 38 & - & 6 & 25 & 90 & 279 & 3.001 & 2.0 & 0.1121 & 0.50 & 1834 & 18 & 1854 & 63 & 101 \\
\hline 39 & - & 11 & 46 & 148 & 510 & 3.358 & 1.9 & 0.1097 & 0.50 & 1794 & 18 & 1680 & 57 & 94 \\
\hline 40 & - & 9 & 46 & 110 & 482 & 3.922 & 1.3 & 0.1141 & 0.50 & 1865 & 18 & 1464 & 33 & 79 \\
\hline 41 & 664 & 6 & 39 & 68 & 403 & 5.118 & 2.8 & 0.1132 & 0.58 & 1852 & 21 & 1151 & 60 & 62 \\
\hline 42 & - & 11 & 47 & 132 & 494 & 3.328 & 1.0 & 0.1111 & 0.50 & 1818 & 18 & 1694 & 31 & 93 \\
\hline 43 & 373 & 16 & 57 & 195 & 598 & 2.735 & 1.1 & 0.2392 & 0.50 & 3114 & 16 & 2009 & 39 & 65 \\
\hline 44 & - & 4 & 14 & 47 & 144 & 2.691 & 1.4 & 0.1505 & 0.50 & 2352 & 17 & 2037 & 48 & 87 \\
\hline 46 & - & 8 & 31 & 92 & 325 & 3.077 & 1.3 & 0.1109 & 0.50 & 1815 & 18 & 1814 & 40 & 100 \\
\hline 47 & - & 6 & 24 & 75 & 251 & 2.978 & 1.6 & 0.1627 & 0.50 & 2484 & 17 & 1867 & 50 & 75 \\
\hline 48 & - & 7 & 29 & 79 & 303 & 3.241 & 1.7 & 0.1098 & 0.50 & 1797 & 18 & 1734 & 51 & 96 \\
\hline 49 & - & 7 & 39 & 82 & 402 & 4.158 & 3.1 & 0.1069 & 0.51 & 1746 & 19 & 1389 & 76 & 80 \\
\hline 50 & - & 14 & 56 & 165 & 588 & 3.160 & 1.1 & 0.1102 & 0.50 & 1802 & 18 & 1772 & 33 & 98 \\
\hline 51 & & 3 & 15 & 41 & 156 & 3.388 & 1.2 & 0.1313 & 0.50 & 2116 & 18 & 1667 & 34 & 79 \\
\hline 52 & & 7 & 29 & 88 & 302 & 3.045 & 1.1 & 0.1111 & 0.50 & 1817 & 18 & 1830 & 35 & 101 \\
\hline 53 & - & 8 & 32 & 92 & 332 & 3.205 & 1.1 & 0.1099 & 0.50 & 1797 & 18 & 1751 & 33 & 97 \\
\hline 54 & - & 8 & 50 & 92 & 525 & 4.225 & 3.9 & 0.1313 & 2.36 & 2116 & 83 & 1369 & 96 & 65 \\
\hline 56 & - & 6 & 27 & 76 & 282 & 3.257 & 1.1 & 0.1105 & 0.50 & 1808 & 18 & 1726 & 32 & 95 \\
\hline 57 & - & 2 & 9 & 28 & 93 & 2.868 & 1.1 & 0.1170 & 0.50 & 1911 & 18 & 1928 & 38 & 101 \\
\hline 58 & - & 7 & 20 & 83 & 209 & 2.227 & 1.2 & 0.1584 & 0.50 & 2439 & 17 & 2391 & 47 & 98 \\
\hline 59 & - & 2 & 7 & 21 & 74 & 3.076 & 1.1 & 0.1098 & 0.58 & 1796 & 21 & 1815 & 36 & 101 \\
\hline 60 & - & 8 & 40 & 102 & 422 & 3.657 & 3.3 & 0.1058 & 0.83 & 1728 & 31 & 1558 & 92 & 90 \\
\hline 61 & - & 3 & 14 & 42 & 150 & 3.183 & 1.1 & 0.1112 & 0.50 & 1819 & 18 & 1761 & 33 & 97 \\
\hline 62 & - & 5 & 17 & 54 & 179 & 2.928 & 1.3 & 0.1125 & 0.50 & 1840 & 18 & 1894 & 42 & 103 \\
\hline 63 & 358 & 8 & 50 & 102 & 517 & 4.363 & 1.9 & 0.1104 & 1.10 & 1806 & 40 & 1330 & 46 & 74 \\
\hline 64 & - & 5 & 22 & 62 & 225 & 3.190 & 1.2 & 0.1116 & 0.50 & 1826 & 18 & 1758 & 35 & 96 \\
\hline 65 & - & 7 & 48 & 84 & 500 & 4.971 & 3.6 & 0.0961 & 1.37 & 1550 & 51 & 1181 & 77 & 76 \\
\hline 66 & - & 11 & 84 & 131 & 873 & 5.659 & 2.5 & 0.0955 & 1.16 & 1538 & 44 & 1049 & 48 & 68 \\
\hline 67 & - & 11 & 47 & 136 & 489 & 3.153 & 1.3 & 0.1100 & 0.50 & 1800 & 18 & 1776 & 39 & 99 \\
\hline 68 & - & 7 & 31 & 82 & 320 & 3.372 & 1.1 & 0.1083 & 0.50 & 1771 & 18 & 1674 & 32 & 95 \\
\hline 69 & - & 9 & 62 & 106 & 650 & 4.716 & 5.7 & 0.0960 & 2.61 & 1547 & 98 & 1240 & 128 & 80 \\
\hline 70 & - & 7 & 32 & 79 & 332 & 3.715 & 2.2 & 0.1091 & 0.50 & 1785 & 18 & 1537 & 59 & 86 \\
\hline 71 & - & 9 & 42 & 111 & 439 & 3.515 & 1.1 & 0.1152 & 0.52 & 1882 & 19 & 1614 & 33 & 86 \\
\hline 72 & - & 12 & 44 & 148 & 463 & 2.781 & 1.3 & 0.1418 & 0.50 & 2249 & 17 & 1980 & 45 & 88 \\
\hline 73 & - & 12 & 126 & 149 & 1314 & 7.865 & 1.1 & 0.0856 & 0.71 & 1329 & 28 & 111 & 17 & 58 \\
\hline 74 & - & 7 & 36 & 78 & 372 & 4.244 & 1.6 & 0.1039 & 0.50 & 1695 & 18 & 1364 & 40 & 80 \\
\hline 75 & - & 2 & 13 & 22 & 132 & 4.065 & 5.8 & 0.0989 & 3.09 & 1603 & 115 & 1418 & 145 & 88 \\
\hline 76 & - & 11 & 46 & 137 & 482 & 3.115 & 1.1 & 0.1104 & 0.50 & 1806 & 18 & 1795 & 34 & 99 \\
\hline 77 & - & 6 & 27 & 76 & 283 & 3.331 & 1.3 & 0.1096 & 0.50 & 1792 & 18 & 1692 & 37 & 94 \\
\hline 78 & - & 11 & 74 & 129 & 773 & 5.359 & 1.3 & 0.0965 & 0.50 & 1557 & 19 & 1103 & 27 & 71 \\
\hline 79 & - & 7 & 32 & 80 & 334 & 3.688 & 1.2 & 0.1061 & 0.50 & 1734 & 18 & 1547 & 32 & 89 \\
\hline 80 & - & 7 & 40 & 85 & 414 & 4.108 & 3.7 & 0.1068 & 0.85 & 1745 & 31 & 1405 & 92 & 80 \\
\hline 81 & - & 3 & 8 & 36 & 79 & 1.920 & 1.1 & 0.1835 & 0.50 & 2685 & 17 & 2702 & 49 & 101 \\
\hline A & - & 7 & 14 & 95 & 334 & 3.433 & 1.5 & 0.1133 & 0.50 & 1854 & 8 & 1648 & 43 & 89 \\
\hline B & - & 9 & 9 & 116 & 216 & 1.825 & 1.0 & 0.2068 & 0.50 & 2881 & 4 & 2817 & 46 & 98 \\
\hline C & - & 6 & 10 & 74 & 229 & 2.909 & 1.0 & 0.1121 & 0.50 & 1834 & 8 & 1905 & 34 & 104 \\
\hline $\mathrm{D}$ & - & 4 & 8 & 56 & 180 & 2.956 & 1.6 & 0.1140 & 0.50 & 1864 & 11 & 1878 & 51 & 101 \\
\hline $\mathrm{F}$ & - & 12 & 11 & 151 & 255 & 1.636 & 2.0 & 0.2479 & 0.50 & 3171 & 3 & 3076 & 97 & 97 \\
\hline G & - & 4 & 7 & 56 & 173 & 2.958 & 2.1 & 0.1127 & 0.50 & 1843 & 11 & 1877 & 67 & 102 \\
\hline $\mathrm{H}$ & - & 8 & 13 & 101 & 306 & 2.917 & 1.5 & 0.1117 & 0.50 & 1827 & 7 & 1900 & 48 & 104 \\
\hline 1 & - & 9 & 18 & 119 & 427 & 3.434 & 1.1 & 0.1098 & 0.50 & 1796 & 6 & 1648 & 33 & 92 \\
\hline $\mathrm{J}$ & - & 5 & 8 & 58 & 197 & 3.315 & 1.1 & 0.1107 & 0.50 & 1810 & 11 & 1699 & 34 & 94 \\
\hline K & - & 7 & 13 & 96 & 296 & 2.969 & 1.9 & 0.1143 & 0.50 & 1869 & 7 & 1871 & 61 & 100 \\
\hline $\mathrm{L}$ & - & 4 & 8 & 58 & 182 & 2.896 & 1.3 & 0.1616 & 0.50 & 2473 & 7 & 1912 & 42 & 77 \\
\hline
\end{tabular}


Table 3 (Continued)

\begin{tabular}{|c|c|c|c|c|c|c|c|c|c|c|c|c|c|c|}
\hline Spot & ${ }^{204} \mathrm{~Pb}$ (cps) & ${ }^{206} \mathrm{~Pb}(\mathrm{mV})$ & ${ }^{238} \mathrm{U}(\mathrm{mV})$ & $\mathrm{Pb}(\mathrm{ppm})$ & $\mathrm{U}(\mathrm{ppm})$ & ${ }^{238} \mathrm{U} /{ }^{206} \mathrm{pb}$ & $1 \mathrm{~s} \%$ & ${ }^{207} \mathrm{pb} /{ }^{206} \mathrm{pb}$ & $1 \mathrm{~s} \%$ & ${ }^{207} \mathrm{pb} /{ }^{206} \mathrm{pb}$ & $2 \mathrm{~s}$ abs & ${ }^{206} \mathrm{~Pb} /{ }^{238} \mathrm{U}$ & $2 \mathrm{~s}$ abs & $\% \mathrm{C}$ \\
\hline M & - & 12 & 28 & 156 & 643 & 3.821 & 1.1 & 0.1083 & 0.50 & 1771 & 5 & 1499 & 30 & 85 \\
\hline $\mathrm{N}$ & - & 7 & 24 & 92 & 568 & 5.794 & 1.6 & 0.0943 & 0.64 & 1515 & 24 & 1026 & 30 & 68 \\
\hline 0 & - & 4 & 10 & 49 & 232 & 4.492 & 1.5 & 0.1194 & 0.53 & 1947 & 19 & 1296 & 35 & 67 \\
\hline$P$ & - & 7 & 11 & 96 & 265 & 2.628 & 1.1 & 0.1474 & 0.50 & 2316 & 7 & 2079 & 40 & 90 \\
\hline Q & - & 14 & 33 & 184 & 763 & 3.960 & 1.1 & 0.1074 & 0.50 & 1756 & 4 & 1452 & 29 & 83 \\
\hline $\mathrm{R}$ & - & 2 & 7 & 31 & 166 & 4.972 & 1.5 & 0.1116 & 1.25 & 1826 & 45 & 1181 & 32 & 65 \\
\hline S & - & 9 & 20 & 122 & 458 & 3.455 & 0.9 & 0.1120 & 0.50 & 1833 & 6 & 1639 & 27 & 89 \\
\hline $\mathrm{T}$ & - & 2 & 3 & 20 & 61 & 2.880 & 1.0 & 0.1173 & 0.68 & 1915 & 24 & 1921 & 33 & 100 \\
\hline U & - & 15 & 98 & 196 & 2278 & 10.767 & 1.2 & 0.0606 & 0.50 & 627 & 18 & 573 & 13 & 91 \\
\hline V & - & 6 & 12 & 76 & 270 & 3.197 & 1.6 & 0.1121 & 0.50 & 1834 & 8 & 1754 & 50 & 96 \\
\hline w & - & 9 & 17 & 119 & 401 & 3.120 & 1.0 & 0.1131 & 0.50 & 1849 & 6 & 1792 & 33 & 97 \\
\hline$X$ & - & 6 & 11 & 77 & 262 & 3.088 & 1.0 & 0.1133 & 0.50 & 1853 & 8 & 1808 & 32 & 98 \\
\hline $\mathrm{Y}$ & - & 5 & 9 & 65 & 220 & 3.060 & 1.1 & 0.1128 & 0.50 & 1845 & 10 & 1823 & 34 & 99 \\
\hline $\mathrm{AA}$ & - & 7 & 13 & 90 & 307 & 3.050 & 1.8 & 0.1139 & 0.50 & 1862 & 7 & 1828 & 56 & 98 \\
\hline$A B$ & - & 4 & 32 & 54 & 750 & 12.481 & 1.4 & 0.0699 & 0.50 & 925 & 18 & 497 & 14 & 54 \\
\hline$A C$ & - & 2 & 5 & 30 & 117 & 3.521 & 2.2 & 0.1375 & 0.50 & 2196 & 14 & 1612 & 61 & 73 \\
\hline $\mathrm{AF}$ & - & 6 & 9 & 76 & 214 & 2.651 & 1.1 & 0.1361 & 0.50 & 2178 & 7 & 2063 & 40 & 95 \\
\hline AG & - & 7 & 21 & 97 & 478 & 4.520 & 1.9 & 0.0999 & 0.50 & 1622 & 9 & 1288 & 45 & 79 \\
\hline $\mathrm{AH}$ & - & 3 & 25 & 44 & 588 & 12.272 & 1.6 & 0.0744 & 0.51 & 1051 & 21 & 505 & 16 & 48 \\
\hline $\mathrm{Al}$ & - & 7 & 7 & 95 & 156 & 1.520 & 2.0 & 0.2502 & 0.50 & 3186 & 5 & 3258 & 102 & 102 \\
\hline $\mathrm{AJ}$ & - & 10 & 23 & 127 & 537 & 3.844 & 1.7 & 0.1097 & 0.50 & 1795 & 6 & 1491 & 45 & 83 \\
\hline AK & - & 8 & 15 & 108 & 349 & 2.927 & 1.6 & 0.1130 & 0.50 & 1848 & 6 & 1894 & 52 & 103 \\
\hline $\mathrm{AL}$ & - & 7 & 13 & 87 & 312 & 3.355 & 2.0 & 0.1132 & 0.50 & 1851 & 8 & 1682 & 60 & 91 \\
\hline AM & - & 15 & 33 & 189 & 761 & 3.615 & 1.1 & 0.1499 & 0.50 & 2345 & 4 & 1574 & 31 & 67 \\
\hline $\mathrm{AP}$ & - & 6 & 26 & 79 & 604 & 7.066 & 4.7 & 0.1458 & 1.93 & 2298 & 66 & 853 & 74 & 37 \\
\hline AN & - & 9 & 31 & 122 & 714 & 5.205 & 1.3 & 0.1021 & 0.50 & 1663 & 7 & 1133 & 27 & 68 \\
\hline $\mathrm{AO}$ & - & 4 & 8 & 53 & 179 & 3.043 & 2.7 & 0.1304 & 0.50 & 2103 & 13 & 1832 & 85 & 87 \\
\hline
\end{tabular}
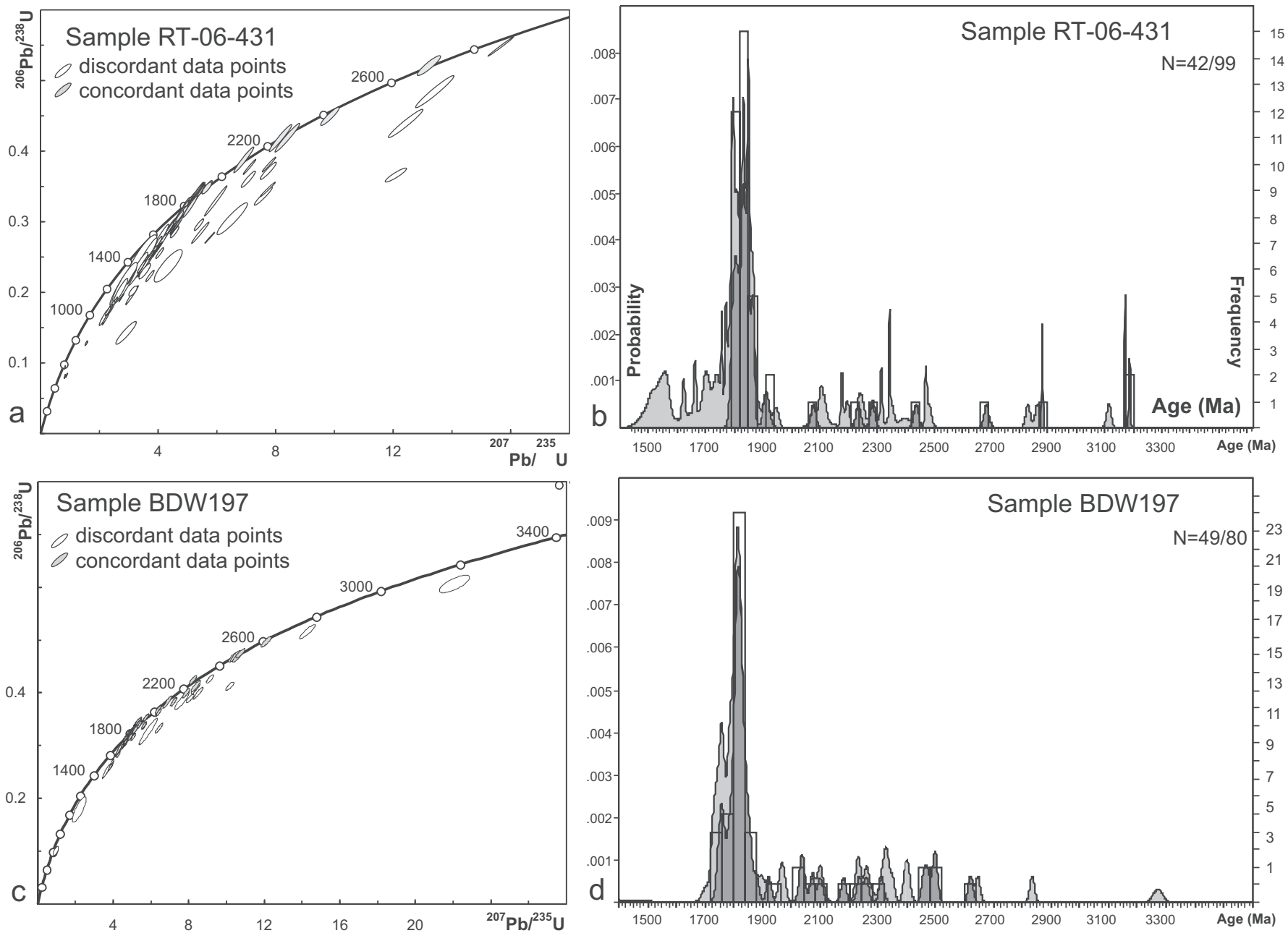

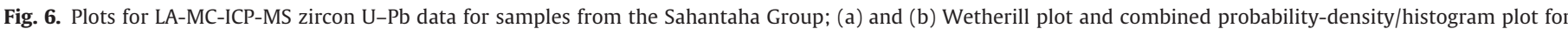

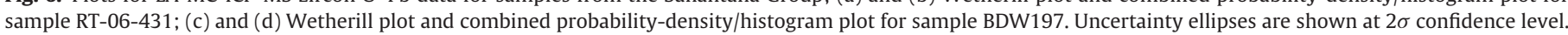
Histogram bin-size is 30 million years for RT-06-431 and 40 million years for BDW197 (only $100 \pm 5 \%$ concordant data are shown in the histogram). 
Table 4

Zircon U-Pb LA-MC-ICP-MS data for sample BDW197.

\begin{tabular}{|c|c|c|c|c|c|c|c|c|c|c|c|c|c|c|}
\hline Spot & ${ }^{204} \mathrm{~Pb}$ (cps) & ${ }^{206} \mathrm{~Pb}(\mathrm{mV})$ & ${ }^{238} \mathrm{U}(\mathrm{mV})$ & $\mathrm{Pb}(\mathrm{ppm})$ & $\mathrm{U}(\mathrm{ppm})$ & ${ }^{238} \mathrm{U} /{ }^{206} \mathrm{pb}$ & $1 s \%$ & ${ }^{207} \mathrm{pb} /{ }^{206} \mathrm{pb}$ & $1 \mathrm{~s} \%$ & ${ }^{207} \mathrm{pb} /{ }^{206} \mathrm{pb}$ & $2 \mathrm{~s}$ abs & ${ }^{206} \mathrm{~Pb} /{ }^{238} \mathrm{U}$ & $2 \mathrm{~s}$ abs & $\% C$ \\
\hline 2 & - & 14 & 52 & 196 & 613 & 3.360 & 1.1 & 0.1094 & 0.50 & 1789 & 18 & 1680 & 31 & 94 \\
\hline 3 & - & 16 & 35 & 225 & 413 & 1.944 & 1.1 & 0.2011 & 0.50 & 2835 & 16 & 2675 & 48 & 94 \\
\hline 6 & - & 12 & 40 & 174 & 469 & 3.034 & 1.3 & 0.1400 & 0.50 & 2227 & 17 & 1837 & 40 & 82 \\
\hline 7 & - & 10 & 35 & 136 & 413 & 3.274 & 1.1 & 0.1073 & 0.50 & 1755 & 18 & 1718 & 32 & 98 \\
\hline 9 & - & 7 & 20 & 93 & 237 & 2.636 & 1.3 & 0.1301 & 0.50 & 2100 & 18 & 2073 & 46 & 99 \\
\hline 10 & - & 8 & 28 & 110 & 335 & 3.216 & 1.1 & 0.1078 & 0.50 & 1763 & 18 & 1745 & 32 & 99 \\
\hline 1rep & - & 7 & 26 & 104 & 314 & 2.957 & 0.9 & 0.1104 & 0.50 & 1807 & 18 & 1878 & 28 & 104 \\
\hline 5rep & - & 8 & 27 & 107 & 324 & 2.970 & 0.9 & 0.1148 & 0.50 & 1877 & 18 & 1871 & 28 & 100 \\
\hline 11 & - & 6 & 23 & 90 & 271 & 2.993 & 0.9 & 0.1104 & 0.50 & 1806 & 18 & 1858 & 29 & 103 \\
\hline 12 & - & 6 & 28 & 85 & 332 & 3.865 & 1.5 & 0.1073 & 0.50 & 1754 & 18 & 1483 & 40 & 85 \\
\hline 13 & - & 25 & 94 & 354 & 1121 & 3.140 & 1.5 & 0.1091 & 0.50 & 1784 & 18 & 1782 & 46 & 100 \\
\hline 14 & - & 9 & 36 & 120 & 423 & 3.458 & 1.7 & 0.1062 & 0.50 & 1734 & 18 & 1637 & 49 & 94 \\
\hline 16 & - & 17 & 74 & 245 & 875 & 3.530 & 1.2 & 0.1061 & 0.50 & 1733 & 18 & 1608 & 33 & 93 \\
\hline 17 & - & 4 & 14 & 52 & 167 & 3.096 & 3.2 & 0.1300 & 0.96 & 2098 & 34 & 1804 & 99 & 86 \\
\hline 18 & - & 12 & 48 & 169 & 564 & 3.252 & 1.0 & 0.1075 & 0.50 & 1758 & 18 & 1729 & 29 & 98 \\
\hline 19 & - & 8 & 32 & 116 & 381 & 3.222 & 0.8 & 0.1067 & 0.50 & 1745 & 18 & 1742 & 24 & 100 \\
\hline 20 & - & 16 & 48 & 225 & 567 & 2.439 & 1.1 & 0.1471 & 0.50 & 2312 & 17 & 2215 & 42 & 96 \\
\hline 21 & - & 9 & 35 & 131 & 421 & 3.125 & 0.9 & 0.1075 & 0.50 & 1758 & 18 & 1790 & 28 & 102 \\
\hline 22 & - & 10 & 42 & 218 & 701 & 3.198 & 0.9 & 0.1161 & 0.50 & 1897 & 18 & 1754 & 28 & 92 \\
\hline 23 & - & 8 & 31 & 184 & 519 & 2.779 & 0.8 & 0.1281 & 0.50 & 2071 & 18 & 1982 & 26 & 96 \\
\hline 24 & - & 4 & 16 & 85 & 269 & 3.102 & 0.8 & 0.1109 & 0.50 & 1814 & 18 & 1801 & 25 & 99 \\
\hline 25 & - & 7 & 29 & 153 & 486 & 3.128 & 0.8 & 0.1107 & 0.50 & 1810 & 18 & 1788 & 25 & 99 \\
\hline 26 & - & 7 & 24 & 158 & 404 & 2.521 & 1.2 & 0.1543 & 0.50 & 2395 & 17 & 2154 & 43 & 90 \\
\hline 27 & - & 35 & 141 & 755 & 2360 & 3.107 & 0.9 & 0.1112 & 0.50 & 1819 & 18 & 1799 & 27 & 99 \\
\hline 28 & - & 14 & 57 & 298 & 945 & 3.112 & 0.8 & 0.1107 & 0.50 & 1811 & 18 & 1796 & 25 & 99 \\
\hline 29 & - & 16 & 78 & 342 & 1309 & 3.763 & 0.8 & 0.1062 & 0.50 & 1735 & 18 & 1519 & 22 & 88 \\
\hline 30 & - & 5 & 21 & 109 & 349 & 3.182 & 0.9 & 0.1102 & 0.50 & 1803 & 18 & 1762 & 27 & 98 \\
\hline 31 & - & 3 & 15 & 76 & 251 & 3.261 & 1.0 & 0.1093 & 0.50 & 1788 & 18 & 1724 & 29 & 96 \\
\hline $31 \mathrm{~B}$ & - & 5 & 19 & 100 & 323 & 3.157 & 0.8 & 0.1098 & 0.50 & 1796 & 18 & 1774 & 24 & 99 \\
\hline 32 & - & 5 & 19 & 102 & 310 & 2.976 & 0.8 & 0.1111 & 0.50 & 1817 & 18 & 1867 & 26 & 103 \\
\hline 33 & - & 9 & 25 & 186 & 410 & 2.147 & 0.9 & 0.1603 & 0.50 & 2459 & 17 & 2465 & 35 & 100 \\
\hline 34 & - & 6 & 30 & 140 & 494 & 3.460 & 0.9 & 0.1071 & 0.50 & 1750 & 18 & 1637 & 27 & 94 \\
\hline 35 & - & 5 & 12 & 117 & 199 & 1.651 & 1.1 & 0.2641 & 1.03 & 3272 & 32 & 3053 & 55 & 93 \\
\hline 36 & - & 4 & 13 & 82 & 211 & 2.484 & 0.8 & 0.1484 & 0.50 & 2327 & 17 & 2181 & 30 & 94 \\
\hline 37 & - & 4 & 11 & 84 & 182 & 2.150 & 0.8 & 0.1640 & 0.50 & 2497 & 17 & 2462 & 33 & 99 \\
\hline 38 & - & 26 & 88 & 560 & 1467 & 2.586 & 0.9 & 0.1503 & 0.50 & 2349 & 17 & 2107 & 33 & 90 \\
\hline 39 & - & 5 & 14 & 101 & 241 & 2.369 & 0.8 & 0.1406 & 0.50 & 2234 & 17 & 2270 & 32 & 102 \\
\hline 40 & - & 21 & 73 & 457 & 1221 & 2.617 & 1.8 & 0.1436 & 0.91 & 2271 & 31 & 2086 & 64 & 92 \\
\hline 41 & - & 6 & 25 & 125 & 416 & 3.297 & 0.9 & 0.1089 & 0.50 & 1780 & 18 & 1708 & 27 & 96 \\
\hline 42 & - & 7 & 29 & 156 & 479 & 2.991 & 0.9 & 0.1105 & 0.50 & 1807 & 18 & 1859 & 30 & 103 \\
\hline 43 & - & 3 & 10 & 58 & 168 & 2.855 & 0.8 & 0.1177 & 0.50 & 1921 & 18 & 1936 & 26 & 101 \\
\hline 44 & - & 14 & 45 & 313 & 749 & 2.360 & 0.8 & 0.1553 & 0.50 & 2405 & 17 & 2277 & 29 & 95 \\
\hline 45 & - & 3 & 10 & 62 & 174 & 2.733 & 0.8 & 0.1254 & 0.50 & 2034 & 18 & 2010 & 27 & 99 \\
\hline 46 & 328 & 4 & 18 & 97 & 301 & 3.051 & 0.8 & 0.1105 & 0.50 & 1808 & 18 & 1827 & 25 & 101 \\
\hline 47 & - & 5 & 23 & 112 & 382 & 3.336 & 0.9 & 0.1091 & 0.50 & 1784 & 18 & 1690 & 27 & 95 \\
\hline 48 & - & 5 & 25 & 119 & 415 & 3.466 & 0.9 & 0.1080 & 0.50 & 1765 & 18 & 1634 & 26 & 93 \\
\hline 49 & - & 5 & 20 & 101 & 339 & 3.336 & 0.8 & 0.1094 & 0.50 & 1790 & 18 & 1690 & 24 & 94 \\
\hline 50 & - & 3 & 24 & 67 & 400 & 5.742 & 5.8 & 0.0887 & 4.08 & 1398 & 156 & 1035 & 110 & 74 \\
\hline 51 & - & 8 & 34 & 185 & 569 & 3.021 & 0.8 & 0.1111 & 0.50 & 1817 & 18 & 1844 & 26 & 101 \\
\hline $50 \mathrm{~B}$ & - & 5 & 24 & 100 & 404 & 4.043 & 2.3 & 0.1044 & 0.78 & 1703 & 29 & 1425 & 58 & 84 \\
\hline $50 \mathrm{~A}$ & - & 2 & 28 & 44 & 465 & 10.556 & 3.7 & 0.0686 & 4.74 & 886 & 196 & 583 & 41 & 66 \\
\hline 52 & - & 7 & 18 & 149 & 305 & 2.019 & 0.8 & 0.1766 & 0.50 & 2621 & 17 & 2594 & 35 & 99 \\
\hline 53 & - & 4 & 12 & 78 & 193 & 2.438 & 0.8 & 0.1793 & 0.50 & 2646 & 17 & 2216 & 29 & 84 \\
\hline 54 & - & 4 & 14 & 76 & 237 & 3.075 & 0.8 & 0.1133 & 0.50 & 1853 & 18 & 1815 & 25 & 98 \\
\hline 55 & - & 9 & 46 & 196 & 766 & 3.876 & 0.9 & 0.1077 & 0.50 & 1762 & 18 & 1480 & 23 & 84 \\
\hline 56 & - & 4 & 18 & 81 & 292 & 3.577 & 0.8 & 0.1090 & 0.50 & 1783 & 18 & 1589 & 24 & 89 \\
\hline 57 & - & 6 & 22 & 132 & 367 & 2.739 & 1.0 & 0.1257 & 0.50 & 2038 & 18 & 2007 & 34 & 98 \\
\hline 58 & - & 10 & 28 & 214 & 464 & 2.137 & 0.9 & 0.1616 & 0.50 & 2473 & 17 & 2475 & 36 & 100 \\
\hline 59 & - & 10 & 39 & 207 & 659 & 3.150 & 0.9 & 0.1114 & 0.50 & 1822 & 18 & 1777 & 29 & 98 \\
\hline 60 & - & 7 & 28 & 153 & 461 & 2.991 & 0.8 & 0.1203 & 0.50 & 1961 & 18 & 1859 & 26 & 95 \\
\hline 61 & - & 5 & 18 & 102 & 306 & 2.987 & 0.9 & 0.1211 & 0.50 & 1972 & 18 & 1862 & 28 & 94 \\
\hline 62 & - & 9 & 31 & 203 & 515 & 2.519 & 0.9 & 0.1426 & 0.50 & 2259 & 17 & 2155 & 34 & 95 \\
\hline 63 & - & 7 & 29 & 150 & 477 & 3.144 & 0.9 & 0.1113 & 0.50 & 1821 & 18 & 1780 & 27 & 98 \\
\hline 64 & - & 9 & 36 & 187 & 600 & 3.136 & 1.3 & 0.1107 & 0.50 & 1811 & 18 & 1784 & 41 & 99 \\
\hline 65 & - & 3 & 11 & 60 & 185 & 3.055 & 0.8 & 0.1117 & 0.50 & 1827 & 18 & 1825 & 26 & 100 \\
\hline 66 & - & 21 & 81 & 456 & 1349 & 2.900 & 0.8 & 0.1119 & 0.50 & 1831 & 18 & 1910 & 28 & 104 \\
\hline 67 & - & 6 & 17 & 133 & 284 & 2.113 & 0.8 & 0.1641 & 0.50 & 2498 & 17 & 2498 & 34 & 100 \\
\hline 68 & - & 6 & 26 & 132 & 437 & 3.316 & 1.1 & 0.1104 & 0.50 & 1806 & 18 & 1699 & 32 & 94 \\
\hline 69 & - & 2 & 9 & 52 & 156 & 2.992 & 0.8 & 0.1120 & 0.50 & 1832 & 18 & 1859 & 25 & 101 \\
\hline 70 & - & 1 & 5 & 28 & 81 & 2.924 & 0.8 & 0.1120 & 0.82 & 1831 & 30 & 1897 & 26 & 104 \\
\hline 71 & - & 11 & 40 & 249 & 660 & 2.631 & 0.9 & 0.1363 & 0.50 & 2181 & 17 & 2077 & 32 & 95 \\
\hline 72 & - & 19 & 61 & 413 & 1024 & 2.455 & 0.8 & 0.1486 & 0.50 & 2330 & 17 & 2203 & 30 & 95 \\
\hline 73 & - & 15 & 59 & 329 & 986 & 2.964 & 0.8 & 0.1122 & 0.50 & 1836 & 18 & 1874 & 26 & 102 \\
\hline 74 & - & 7 & 29 & 142 & 477 & 3.337 & 0.9 & 0.1106 & 0.50 & 1809 & 18 & 1689 & 25 & 93 \\
\hline 75 & - & 4 & 19 & 97 & 313 & 3.200 & 0.9 & 0.1111 & 0.50 & 1817 & 18 & 1753 & 26 & 96 \\
\hline 76 & - & 2 & 8 & 46 & 138 & 2.948 & 0.9 & 0.1131 & 0.52 & 1850 & 19 & 1883 & 28 & 102 \\
\hline 77 & - & 5 & 21 & 109 & 346 & 3.195 & 0.8 & 0.1114 & 0.50 & 1823 & 18 & 1755 & 24 & 96 \\
\hline 78 & - & 2 & 7 & 37 & 115 & 3.048 & 0.9 & 0.1134 & 0.61 & 1854 & 22 & 1829 & 29 & 99 \\
\hline 79 & - & 3 & 11 & 57 & 182 & 3.200 & 0.8 & 0.1123 & 0.50 & 1838 & 18 & 1753 & 26 & 95 \\
\hline 80 & - & 8 & 43 & 175 & 719 & 4.057 & 0.9 & 0.1057 & 0.50 & 1726 & 18 & 1420 & 22 & 82 \\
\hline
\end{tabular}


Table 5

Zircon U-Pb LA-MC-ICP-MS data for sample CP183b.

\begin{tabular}{|c|c|c|c|c|c|c|c|c|c|c|c|c|c|c|}
\hline Spot & ${ }^{204} \mathrm{~Pb}(\mathrm{cps})$ & ${ }^{206} \mathrm{~Pb}(\mathrm{mV})$ & ${ }^{238} \mathrm{U}(\mathrm{mV})$ & $\mathrm{Pb}(\mathrm{ppm})$ & $\mathrm{U}(\mathrm{ppm})$ & ${ }^{238} \mathrm{U} /{ }^{206} \mathrm{pb}$ & $1 \mathrm{~s} \%$ & ${ }^{207} \mathrm{pb} /{ }^{206} \mathrm{pb}$ & ls\% & ${ }^{207} \mathrm{pb} /{ }^{206} \mathrm{pb}$ & $2 \mathrm{~s}$ abs & ${ }^{206} \mathrm{~Pb} /{ }^{238} \mathrm{U}$ & $2 \mathrm{~s}$ abs & $\% \mathrm{C}$ \\
\hline 2 & 310 & 6 & 23 & 99 & 289 & 2.991 & 1.2 & 0.1149 & 0.50 & 1878 & 18 & 1860 & 37 & 99 \\
\hline 3 & - & 1 & 6 & 24 & 71 & 3.078 & 1.2 & 0.1143 & 0.73 & 1869 & 26 & 1814 & 37 & 97 \\
\hline 4 & - & 21 & 90 & 349 & 1118 & 3.260 & 1.1 & 0.1145 & 0.50 & 1872 & 18 & 1725 & 34 & 92 \\
\hline 5 & - & 6 & 24 & 101 & 299 & 3.008 & 1.2 & 0.1148 & 0.50 & 1876 & 18 & 1850 & 38 & 99 \\
\hline 6 & - & 6 & 23 & 102 & 288 & 2.848 & 1.3 & 0.1300 & 0.50 & 2098 & 18 & 1940 & 42 & 92 \\
\hline 7 & 332 & 9 & 36 & 155 & 448 & 2.904 & 1.1 & 0.1295 & 0.50 & 2091 & 18 & 1908 & 38 & 91 \\
\hline 8 & 533 & 7 & 42 & 123 & 523 & 4.329 & 1.3 & 0.1434 & 0.50 & 2268 & 17 & 1340 & 31 & 59 \\
\hline 9 & 386 & 4 & 22 & 75 & 271 & 3.625 & 1.2 & 0.1108 & 0.50 & 1813 & 18 & 1571 & 33 & 87 \\
\hline 10 & 440 & 6 & 19 & 105 & 238 & 2.282 & 1.2 & 0.1627 & 0.50 & 2484 & 17 & 2343 & 47 & 94 \\
\hline 11 & 486 & 4 & 17 & 70 & 210 & 3.015 & 1.2 & 0.1131 & 0.50 & 1850 & 18 & 1847 & 37 & 100 \\
\hline 12 & 422 & 2 & 10 & 40 & 121 & 3.028 & 1.2 & 0.1126 & 0.50 & 1841 & 18 & 1840 & 38 & 100 \\
\hline 13 & 526 & 22 & 71 & 374 & 885 & 2.379 & 1.2 & 0.1732 & 0.50 & 2589 & 17 & 2262 & 45 & 87 \\
\hline 14 & 674 & 7 & 27 & 116 & 335 & 2.915 & 1.4 & 0.1512 & 0.50 & 2360 & 17 & 1901 & 44 & 81 \\
\hline 16 & - & 8 & 39 & 142 & 484 & 3.426 & 1.1 & 0.1157 & 0.50 & 1890 & 18 & 1651 & 33 & 87 \\
\hline 18 & - & 9 & 27 & 150 & 331 & 2.175 & 1.2 & 0.1623 & 0.50 & 2480 & 17 & 2438 & 49 & 98 \\
\hline 19 & - & 6 & 24 & 96 & 297 & 3.082 & 1.1 & 0.1141 & 0.50 & 1866 & 18 & 1811 & 35 & 97 \\
\hline 20 & - & 2 & 10 & 40 & 123 & 3.065 & 1.2 & 0.1134 & 0.50 & 1855 & 18 & 1821 & 38 & 98 \\
\hline 21 & - & 3 & 14 & 47 & 177 & 3.702 & 1.1 & 0.1124 & 0.50 & 1839 & 18 & 1541 & 31 & 84 \\
\hline 22 & - & 10 & 27 & 162 & 334 & 2.038 & 1.2 & 0.1781 & 0.50 & 2635 & 17 & 2574 & 52 & 98 \\
\hline 23 & - & 9 & 40 & 146 & 495 & 3.397 & 1.3 & 0.1109 & 0.50 & 1814 & 18 & 1663 & 37 & 92 \\
\hline 24 & - & 4 & 17 & 70 & 216 & 3.035 & 1.2 & 0.1224 & 1.41 & 1992 & 50 & 1836 & 38 & 92 \\
\hline 25 & - & 12 & 47 & 196 & 593 & 3.055 & 1.2 & 0.1252 & 0.50 & 2032 & 18 & 1825 & 37 & 90 \\
\hline $26 B$ & - & 2 & 5 & 29 & 67 & 2.311 & 1.2 & 0.1533 & 0.50 & 2383 & 17 & 2318 & 48 & 97 \\
\hline 27 & - & 15 & 66 & 252 & 823 & 3.235 & 1.2 & 0.1163 & 0.50 & 1900 & 18 & 1736 & 37 & 91 \\
\hline 28 & - & 13 & 40 & 226 & 501 & 2.195 & 1.3 & 0.1626 & 0.50 & 2483 & 17 & 2420 & 51 & 97 \\
\hline 29 & - & 7 & 24 & 113 & 297 & 2.584 & 1.2 & 0.1430 & 0.50 & 2264 & 17 & 2109 & 43 & 93 \\
\hline 30 & - & 14 & 61 & 242 & 758 & 3.081 & 1.2 & 0.1131 & 0.50 & 1850 & 18 & 1812 & 37 & 98 \\
\hline 31 & - & 5 & 19 & 77 & 234 & 2.997 & 1.2 & 0.1152 & 0.50 & 1882 & 18 & 1856 & 37 & 99 \\
\hline 32 & - & 5 & 13 & 80 & 167 & 2.053 & 1.2 & 0.1811 & 0.50 & 2663 & 17 & 2558 & 49 & 96 \\
\hline 33 & - & 2 & 9 & 34 & 114 & 3.195 & 1.1 & 0.1205 & 0.90 & 1964 & 32 & 1756 & 34 & 89 \\
\hline 34 & - & 2 & 9 & 41 & 107 & 2.507 & 1.1 & 0.1520 & 0.50 & 2369 & 17 & 2164 & 42 & 91 \\
\hline 35 & - & 4 & 18 & 69 & 220 & 3.089 & 1.1 & 0.1142 & 0.50 & 1868 & 18 & 1808 & 36 & 97 \\
\hline 36 & - & 4 & 20 & 73 & 254 & 3.381 & 1.3 & 0.1134 & 0.73 & 1855 & 26 & 1670 & 39 & 90 \\
\hline 37 & - & 26 & 107 & 429 & 1337 & 2.996 & 1.1 & 0.1157 & 0.50 & 1891 & 18 & 1857 & 36 & 98 \\
\hline 38 & - & 3 & 11 & 57 & 133 & 2.262 & 1.2 & 0.1635 & 0.50 & 2492 & 17 & 2360 & 47 & 95 \\
\hline 39 & - & 3 & 9 & 52 & 118 & 2.198 & 1.2 & 0.1651 & 0.50 & 2509 & 17 & 2417 & 48 & 96 \\
\hline 40 & - & 17 & 72 & 284 & 894 & 3.046 & 1.2 & 0.1137 & 0.50 & 1860 & 18 & 1830 & 38 & 98 \\
\hline 41 & - & 6 & 29 & 106 & 367 & 3.365 & 1.2 & 0.1101 & 0.50 & 1801 & 18 & 1677 & 35 & 93 \\
\hline 42 & - & 3 & 14 & 56 & 172 & 2.992 & 1.2 & 0.1127 & 0.50 & 1843 & 18 & 1859 & 37 & 101 \\
\hline 43 & - & 2 & 8 & 32 & 105 & 3.156 & 1.1 & 0.1115 & 0.55 & 1824 & 20 & 1774 & 35 & 97 \\
\hline 44 & - & 10 & 43 & 173 & 531 & 2.976 & 1.1 & 0.1591 & 0.50 & 2446 & 17 & 1868 & 36 & 76 \\
\hline 45 & - & 3 & 14 & 55 & 173 & 3.059 & 1.2 & 0.1131 & 0.50 & 1850 & 18 & 1823 & 38 & 99 \\
\hline 46 & - & 1 & 8 & 25 & 104 & 3.982 & 1.4 & 0.1047 & 0.81 & 1709 & 30 & 1444 & 36 & 85 \\
\hline 47 & - & 15 & 66 & 248 & 827 & 3.196 & 1.2 & 0.1139 & 0.50 & 1862 & 18 & 1755 & 37 & 94 \\
\hline 48 & - & 4 & 17 & 62 & 211 & 3.270 & 1.2 & 0.1103 & 0.50 & 1804 & 18 & 1720 & 35 & 95 \\
\hline 49 & - & 4 & 13 & 67 & 157 & 2.274 & 1.2 & 0.1592 & 0.50 & 2447 & 17 & 2350 & 45 & 96 \\
\hline 50 & - & 6 & 28 & 106 & 346 & 3.153 & 1.2 & 0.1131 & 0.50 & 1850 & 18 & 1776 & 38 & 96 \\
\hline 51 & - & 13 & 62 & 226 & 776 & 3.288 & 1.2 & 0.1127 & 0.50 & 1843 & 18 & 1712 & 35 & 93 \\
\hline 52 & - & 15 & 62 & 253 & 780 & 2.986 & 1.2 & 0.1243 & 0.50 & 2018 & 18 & 1862 & 38 & 92 \\
\hline 53 & - & 3 & 8 & 45 & 97 & 2.075 & 1.3 & 0.1940 & 0.50 & 2776 & 16 & 2535 & 53 & 91 \\
\hline 54 & - & 3 & 10 & 56 & 127 & 2.190 & 1.2 & 0.1636 & 0.50 & 2494 & 17 & 2424 & 48 & 97 \\
\hline 55 & - & 1 & 5 & 21 & 67 & 3.061 & 1.2 & 0.1132 & 0.78 & 1852 & 28 & 1822 & 37 & 98 \\
\hline 56 & - & 6 & 24 & 95 & 297 & 3.002 & 1.3 & 0.1136 & 0.50 & 1857 & 18 & 1853 & 42 & 100 \\
\hline 57 & 587 & 3 & 18 & 58 & 225 & 3.738 & 1.4 & 0.1423 & 0.81 & 2256 & 28 & 1528 & 39 & 68 \\
\hline 58 & - & 4 & 17 & 64 & 217 & 3.225 & 1.2 & 0.1150 & 0.50 & 1879 & 18 & 1741 & 37 & 93 \\
\hline 59 & - & 10 & 40 & 165 & 504 & 2.944 & 1.2 & 0.1187 & 0.50 & 1936 & 18 & 1885 & 38 & 97 \\
\hline 60 & - & 5 & 23 & 86 & 284 & 3.148 & 1.2 & 0.1118 & 0.50 & 1828 & 18 & 1778 & 37 & 97 \\
\hline 61 & - & 5 & 16 & 88 & 206 & 2.239 & 1.1 & 0.1583 & 0.50 & 2438 & 17 & 2380 & 45 & 98 \\
\hline 62 & - & 6 & 23 & 106 & 286 & 2.429 & 2.1 & 0.1461 & 1.11 & 2301 & 38 & 2222 & 80 & 97 \\
\hline 63 & - & 5 & 14 & 83 & 171 & 1.969 & 1.1 & 0.1839 & 0.50 & 2689 & 17 & 2648 & 49 & 98 \\
\hline 65 & - & 10 & 30 & 162 & 372 & 2.227 & 1.2 & 0.1752 & 0.50 & 2608 & 17 & 2391 & 50 & 92 \\
\hline 666 & - & 5 & 20 & 83 & 253 & 2.935 & 1.2 & 0.1185 & 0.50 & 1934 & 18 & 1890 & 41 & 98 \\
\hline 67 & - & 11 & 41 & 181 & 506 & 2.676 & 1.2 & 0.1357 & 0.50 & 2174 & 17 & 2047 & 41 & 94 \\
\hline 68 & - & 8 & 24 & 140 & 305 & 2.077 & 1.2 & 0.1657 & 0.50 & 2515 & 17 & 2533 & 50 & 101 \\
\hline 69 & - & 7 & 31 & 123 & 390 & 3.091 & 1.4 & 0.1137 & 0.50 & 1859 & 18 & 1807 & 43 & 97 \\
\hline 70 & - & 7 & 26 & 117 & 328 & 2.664 & 1.3 & 0.1253 & 0.50 & 2033 & 18 & 2055 & 45 & 101 \\
\hline 71 & - & 6 & 19 & 99 & 239 & 2.335 & 1.2 & 0.1587 & 0.55 & 2442 & 19 & 2298 & 47 & 94 \\
\hline 73 & - & 4 & 18 & 71 & 219 & 2.922 & 1.1 & 0.1136 & 0.50 & 1857 & 18 & 1898 & 37 & 102 \\
\hline 74 & - & 6 & 28 & 106 & 351 & 3.219 & 1.2 & 0.1114 & 0.50 & 1822 & 18 & 1744 & 38 & 96 \\
\hline 75 & - & 3 & 15 & 58 & 184 & 3.043 & 1.2 & 0.1138 & 0.50 & 1861 & 18 & 1832 & 39 & 98 \\
\hline 76 & - & 5 & 19 & 87 & 242 & 2.674 & 1.2 & 0.1280 & 0.50 & 2071 & 18 & 2048 & 43 & 99 \\
\hline 77 & - & 18 & 76 & 306 & 951 & 2.994 & 1.2 & 0.1197 & 0.50 & 1951 & 18 & 1858 & 40 & 95 \\
\hline 78 & - & 5 & 20 & 79 & 249 & 3.006 & 1.3 & 0.1145 & 0.50 & 1872 & 18 & 1851 & 41 & 99 \\
\hline 79 & - & 3 & 10 & 51 & 123 & 2.318 & 1.2 & 0.1615 & 0.50 & 2471 & 17 & 2312 & 47 & 94 \\
\hline 80 & - & 7 & 29 & 122 & 362 & 2.809 & 1.3 & 0.1190 & 0.50 & 1941 & 18 & 1963 & 44 & 101 \\
\hline 82 & 327 & 12 & 61 & 209 & 760 & 3.485 & 1.2 & 0.1101 & 0.50 & 1801 & 18 & 1626 & 35 & 90 \\
\hline 84 & - & 5 & 18 & 83 & 221 & 2.579 & 1.3 & 0.1513 & 0.50 & 2360 & 17 & 2112 & 48 & 89 \\
\hline 85 & - & 1 & 4 & 17 & 53 & 3.004 & 1.2 & 0.1141 & 0.95 & 1866 & 34 & 1853 & 38 & 99 \\
\hline 86 & 339 & 9 & 40 & 152 & 505 & 3.180 & 1.3 & 0.1174 & 0.50 & 1917 & 18 & 1763 & 41 & 92 \\
\hline 87 & - & 24 & 76 & 404 & 948 & 2.245 & 1.2 & 0.1604 & 0.50 & 2460 & 17 & 2375 & 47 & 97 \\
\hline 88 & - & 16 & 70 & 273 & 868 & 3.022 & 1.2 & 0.1130 & 0.50 & 1848 & 18 & 1843 & 38 & 100 \\
\hline 89 & - & 8 & 33 & 130 & 413 & 3.024 & 1.2 & 0.1129 & 0.50 & 1846 & 18 & 1842 & 39 & 100 \\
\hline
\end{tabular}



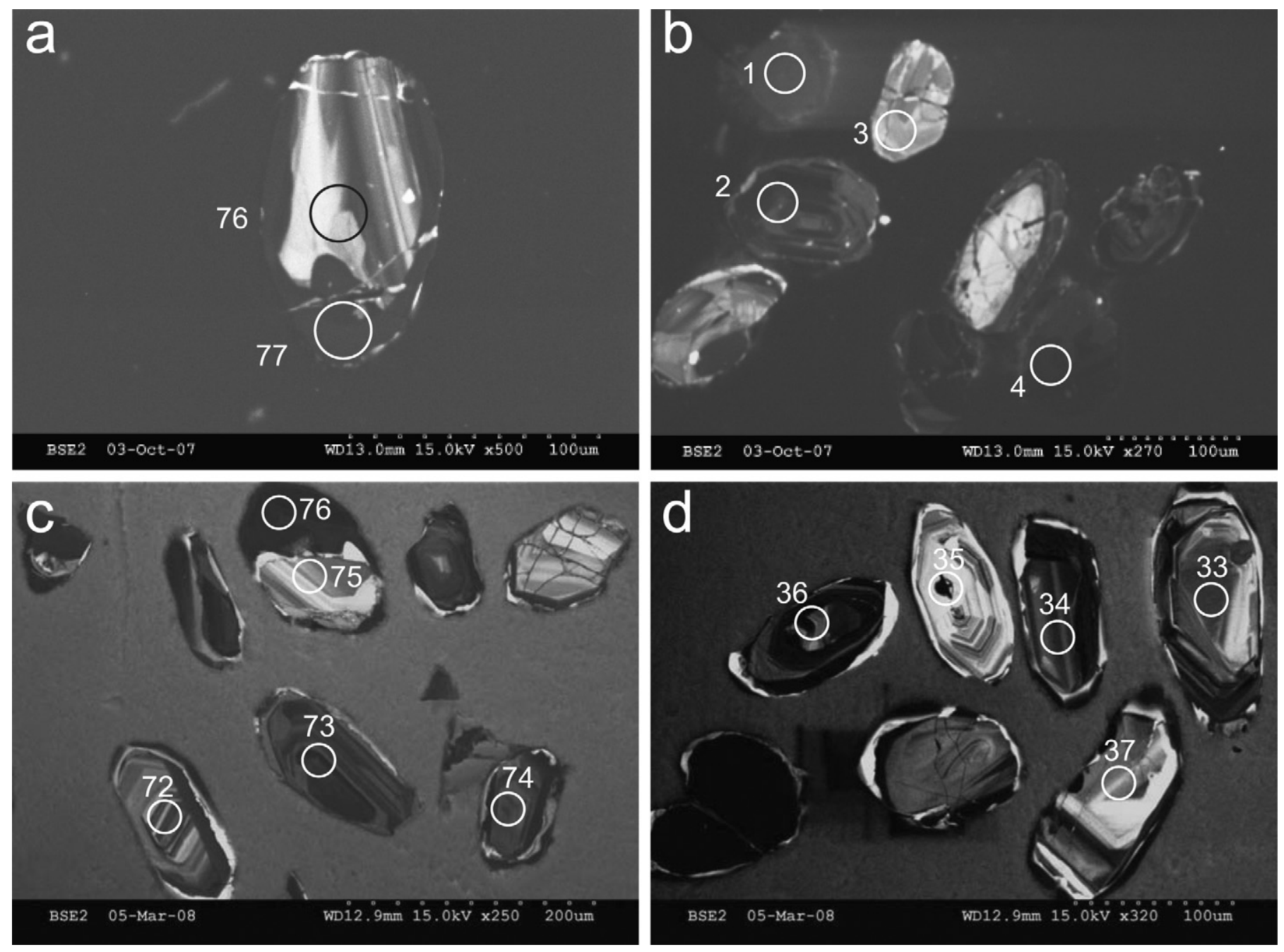

Fig. 7. Cathodo-luminescence imagery of selected zircon grains from samples of the Maha Group; sample CP183b (a, b) and sample PP727 (c, d).

uncertainty of the data point ${ }^{207} \mathrm{~Pb} /{ }^{206} \mathrm{~Pb}$ ages of $19 \mathrm{Ma}(2 \sigma)$ and a histogram bin width efficiency of $82.7 \%$ (at 40 Ma bin width). The probability density distribution indicates age maxima at: 2690 , 2660, 2640, 2510, 2480, 2450, 2380, 2300, 2070, 2030, 1940 and $1860 \mathrm{Ma}$ (Fig. 6d) rounded to the nearest $10 \mathrm{Ma}$ (Fig. $8 \mathrm{~b}$ ). Maxima within uncertainty define age ranges of 2690-2640, 2510-2450 and 2070-2030 Ma. The largest mode is that at $1860 \mathrm{Ma}$ which comprises 22 of the 47 concordant data points. The ${ }^{207} \mathrm{~Pb} /{ }^{206} \mathrm{~Pb}$ age of the youngest detrital zircon is $1804 \pm 18 \mathrm{Ma}(2 \sigma)$, which provides a maximum age of deposition for the sediment. Rim analysis 77 is characterised by high $U(951 \mathrm{ppm})$ and provides an age of $1951 \pm 18 \mathrm{Ma}(2 \sigma)$ and possibly records a metamorphic event affecting the source rock prior to incorporation into the quartzite. We note, however, that this analysis may have incorporated core material and therefore represent a mixed age.

Sample PP727 was taken from outcrops of garnet-bearing quartzite, interbanded on a cm- to dm-scale with kyanite-garnetbiotite gneiss located within the MDZ - see sample location on Fig. 3. 91 analyses were conducted on a variety of grains (Fig. 7c and d), of which 39 are within $100 \pm 5 \%$ concordant (Fig. 8c). Several severely discordant data points indicate some Mesoarchaean components, but based on the most concordant ${ }^{207} \mathrm{~Pb} /{ }^{206} \mathrm{~Pb}$ data only, a mean uncertainty of the data point ages of $15 \mathrm{Ma}(2 \sigma)$ and a histogram bin width efficiency of $81.8 \%$ (at $30 \mathrm{Ma}$ bin width), the probability density distribution indicates age maxima at: 2770, 2720, 2630, 2590, 2520, 2490, 2160, 1940,
1920, 1870, 1860, 1850 and $1840 \mathrm{Ma}$ (Fig. 8d) rounded to the nearest $10 \mathrm{Ma}$. Maxima within uncertainty define age ranges of $2520-2490,1940-1920$ and $1870-1840 \mathrm{Ma}$. The largest mode is that at $1870-1840$ Ma which comprises 19 of the 39 concordant data points. The youngest concordant detrital zircon grain yielded a ${ }^{207} \mathrm{~Pb} /{ }^{206} \mathrm{~Pb}$ age of $1797 \pm 18 \mathrm{Ma}$, which records the maximum age of deposition of the quartzite agreeing well with that from sample CP183b. A metamorphic rim on one zircon grain was large enough to allow a determination (analysis 76), and yielded a nearconcordant ${ }^{206} \mathrm{~Pb} /{ }^{238} \mathrm{U}$ age of $531 \pm 8 \mathrm{Ma}$ (106\% concordant), which is taken to be a good approximation for the timing of its crystallisation (Table 6). This rim analysis is characterised by a high $U$ content of 1433 ppm, which together with its CL-unzoned nature (Fig. 7c), suggests that it grew during a late Neoproterozoic metamorphic event, probably associated with the emplacement of late tectonic granites at this time.

\subsection{Itremo Group}

The two samples of Itremo Group rocks that were analysed were collected from within the Ikalamavony Sub-domain of the ItremoIkalamavony Belt (Fig. 3). Quartzite sample PF06035 was collected from a narrow unit infolded with marbles and amphibolites in the Itremo-Ikalamavony Domain in the southwestern parts of the Bekodoka Inlier (Figs. 2 and 3). The quartzite sample contained abundant zircon with a wide variety of shapes from transparent 
Table 6

Zircon U-Pb LA-MC-ICP-MS data for sample PP727.

\begin{tabular}{|c|c|c|c|c|c|c|c|c|c|c|c|c|c|c|}
\hline Spot & $204 \mathrm{~Pb}$ (cps) & ${ }^{206} \mathrm{~Pb}(\mathrm{mV})$ & ${ }^{238} \mathrm{U}(\mathrm{mV})$ & $\mathrm{Pb}(\mathrm{ppm})$ & $\mathrm{U}(\mathrm{ppm})$ & ${ }^{238} \mathrm{U} /{ }^{206} \mathrm{pb}$ & $1 \mathrm{~s} \%$ & ${ }^{207} \mathrm{pb} /{ }^{206} \mathrm{pb}$ & $1 \mathrm{~s} \%$ & ${ }^{207} \mathrm{pb} /{ }^{206} \mathrm{pb}$ & $2 \mathrm{~s}$ abs & ${ }^{206} \mathrm{~Pb} /{ }^{238} \mathrm{U}$ & $2 \mathrm{~s}$ abs & $\% \mathrm{C}$ \\
\hline 3 & - & 13 & 25 & 101 & 343 & 3.011 & 0.8 & 0.1139 & 0.50 & 1862 & 18 & 1849 & 26 & 99 \\
\hline 5 & 504 & 8 & 15 & 58 & 215 & 3.155 & 0.9 & 0.1111 & 0.50 & 1817 & 18 & 1775 & 27 & 98 \\
\hline 1 & - & 3 & 6 & 68 & 231 & 3.373 & 0.9 & 0.1114 & 0.50 & 1822 & 18 & 1674 & 26 & 92 \\
\hline 2 & - & 3 & 8 & 61 & 294 & 4.714 & 2.5 & 0.1078 & 1.09 & 1763 & 40 & 1240 & 56 & 70 \\
\hline 3 & - & 4 & 7 & 86 & 260 & 3.122 & 1.0 & 0.1152 & 0.50 & 1884 & 18 & 1791 & 30 & 95 \\
\hline 4 & - & 3 & 6 & 72 & 220 & 3.175 & 0.9 & 0.1146 & 0.50 & 1873 & 18 & 1765 & 28 & 94 \\
\hline 5 & - & 3 & 6 & 61 & 225 & 3.613 & 1.1 & 0.1099 & 0.54 & 1798 & 19 & 1575 & 31 & 88 \\
\hline 6 & - & 11 & 13 & 254 & 492 & 1.918 & 1.1 & 0.3143 & 0.50 & 3542 & 15 & 2705 & 47 & 76 \\
\hline 7 & - & 7 & 15 & 150 & 559 & 3.490 & 0.9 & 0.1099 & 0.50 & 1797 & 18 & 1624 & 26 & 90 \\
\hline 8 & 417 & 5 & 8 & 117 & 281 & 2.301 & 1.0 & 0.1619 & 0.50 & 2476 & 17 & 2326 & 39 & 94 \\
\hline 11 & - & 16 & 26 & 365 & 958 & 2.557 & 1.1 & 0.1561 & 0.50 & 2414 & 17 & 2128 & 39 & 88 \\
\hline 12 & - & 7 & 14 & 162 & 499 & 3.005 & 1.1 & 0.1205 & 0.58 & 1964 & 21 & 1852 & 35 & 94 \\
\hline 14 & - & 2 & 5 & 55 & 185 & 3.233 & 1.5 & 0.1471 & 0.60 & 2312 & 21 & 1738 & 45 & 75 \\
\hline 16 & - & 7 & 15 & 168 & 547 & 3.078 & 0.8 & 0.1127 & 0.50 & 1843 & 18 & 1814 & 25 & 98 \\
\hline 17 & - & 5 & 10 & 113 & 367 & 3.067 & 0.9 & 0.1183 & 0.50 & 1930 & 18 & 1819 & 27 & 94 \\
\hline 18 & - & 10 & 21 & 229 & 788 & 3.225 & 0.9 & 0.1132 & 0.50 & 1852 & 18 & 1741 & 28 & 94 \\
\hline 19 & - & 15 & 20 & 338 & 720 & 1.969 & 0.8 & 0.1933 & 0.50 & 2770 & 16 & 2648 & 34 & 96 \\
\hline 20 & - & 7 & 10 & 161 & 368 & 2.116 & 0.8 & 0.1735 & 0.50 & 2592 & 17 & 2494 & 33 & 96 \\
\hline 21 & - & 7 & 9 & 156 & 319 & 1.928 & 0.8 & 0.1870 & 0.50 & 2716 & 16 & 2694 & 34 & 99 \\
\hline 22 & - & 8 & 17 & 189 & 628 & 3.164 & 0.8 & 0.1123 & 0.50 & 1836 & 18 & 1770 & 25 & 96 \\
\hline 23 & - & 4 & 6 & 95 & 221 & 2.255 & 0.8 & 0.1679 & 0.50 & 2536 & 17 & 2366 & 32 & 93 \\
\hline 24 & - & 3 & 5 & 60 & 171 & 2.626 & 1.5 & 0.1673 & 0.94 & 2531 & 31 & 2080 & 53 & 82 \\
\hline 25 & - & 4 & 7 & 95 & 250 & 2.444 & 1.2 & 0.1617 & 0.50 & 2473 & 17 & 2211 & 45 & 89 \\
\hline 26 & - & 11 & 19 & 258 & 699 & 2.495 & 1.1 & 0.1526 & 0.50 & 2375 & 17 & 2172 & 39 & 91 \\
\hline 33 & - & 6 & 8 & 136 & 305 & 2.069 & 0.8 & 0.1669 & 0.50 & 2527 & 17 & 2541 & 33 & 101 \\
\hline 34 & - & 6 & 10 & 134 & 369 & 2.509 & 0.8 & 0.1349 & 0.50 & 2163 & 17 & 2163 & 29 & 100 \\
\hline 35 & - & 3 & 5 & 70 & 192 & 2.544 & 1.2 & 0.1558 & 0.61 & 2410 & 21 & 2137 & 45 & 89 \\
\hline 36 & - & 11 & 25 & 246 & 937 & 3.395 & 1.6 & 0.1268 & 1.27 & 2055 & 45 & 1664 & 47 & 81 \\
\hline 37 & - & 4 & 6 & 92 & 225 & 2.260 & 0.8 & 0.1618 & 0.50 & 2475 & 17 & 2362 & 32 & 95 \\
\hline 39 & - & 3 & 5 & 75 & 170 & 2.123 & 0.8 & 0.1654 & 0.50 & 2511 & 17 & 2488 & 33 & 99 \\
\hline 40 & - & 4 & 7 & 92 & 268 & 2.592 & 0.9 & 0.1351 & 0.50 & 2166 & 17 & 2103 & 31 & 97 \\
\hline 41 & - & 16 & 28 & 373 & 1031 & 2.474 & 0.8 & 0.1556 & 0.50 & 2409 & 17 & 2188 & 31 & 91 \\
\hline 42 & - & 5 & 9 & 115 & 336 & 2.615 & 1.1 & 0.1460 & 0.65 & 2299 & 22 & 2088 & 40 & 91 \\
\hline 45 & - & 6 & 9 & 144 & 328 & 2.097 & 0.8 & 0.1684 & 0.50 & 2542 & 17 & 2514 & 33 & 99 \\
\hline 46 & - & 3 & 5 & 69 & 183 & 2.431 & 0.9 & 0.1581 & 0.50 & 2436 & 17 & 2221 & 32 & 91 \\
\hline 47 & - & 7 & 16 & 169 & 583 & 3.056 & 1.2 & 0.1575 & 0.56 & 2429 & 19 & 1825 & 39 & 75 \\
\hline 48 & - & 8 & 21 & 186 & 766 & 3.703 & 0.8 & 0.1108 & 0.50 & 1813 & 18 & 1541 & 23 & 85 \\
\hline 49 & - & 8 & 17 & 193 & 627 & 3.023 & 0.8 & 0.1188 & 0.50 & 1938 & 18 & 1842 & 26 & 95 \\
\hline 50 & - & 4 & 8 & 86 & 284 & 3.037 & 0.8 & 0.1125 & 0.50 & 1840 & 18 & 1835 & 25 & 100 \\
\hline 51 & - & 4 & 9 & 102 & 334 & 3.034 & 0.8 & 0.1141 & 0.50 & 1866 & 18 & 1837 & 25 & 98 \\
\hline 52 & - & 2 & 5 & 50 & 185 & 3.325 & 0.8 & 0.1099 & 0.50 & 1798 & 18 & 1695 & 24 & 94 \\
\hline 53 & - & 13 & 41 & 317 & 1211 & 3.728 & 0.9 & 0.1070 & 0.50 & 1750 & 18 & 1532 & 24 & 88 \\
\hline 54 & - & 3 & 8 & 64 & 228 & 3.489 & 0.9 & 0.1066 & 0.52 & 1742 & 19 & 1624 & 26 & 93 \\
\hline 55 & - & 16 & 43 & 382 & 1274 & 3.238 & 0.8 & 0.1115 & 0.50 & 1824 & 18 & 1735 & 25 & 95 \\
\hline 56 & - & 6 & 19 & 142 & 572 & 3.628 & 1.8 & 0.1117 & 0.69 & 1826 & 25 & 1569 & 51 & 86 \\
\hline 58 & - & 22 & 70 & 542 & 2080 & 3.645 & 0.9 & 0.1290 & 0.50 & 2084 & 18 & 1563 & 24 & 75 \\
\hline 59 & - & 14 & 32 & 333 & 945 & 2.738 & 0.9 & 0.1511 & 0.50 & 2358 & 17 & 2007 & 29 & 85 \\
\hline 60 & - & 4 & 9 & 87 & 270 & 3.031 & 0.9 & 0.1125 & 0.50 & 1841 & 18 & 1838 & 29 & 100 \\
\hline 61 & - & 21 & 59 & 516 & 1738 & 3.240 & 1.2 & 0.1129 & 0.50 & 1846 & 18 & 1734 & 37 & 94 \\
\hline 62 & - & 5 & 9 & 122 & 267 & 1.913 & 2.4 & 0.2695 & 0.93 & 3303 & 29 & 2711 & 106 & 82 \\
\hline 63 & 314 & 6 & 15 & 136 & 450 & 3.140 & 1.1 & 0.1125 & 0.50 & 1840 & 18 & 1782 & 33 & 97 \\
\hline 64 & - & 10 & 21 & 232 & 618 & 2.481 & 1.0 & 0.1570 & 0.50 & 2423 & 17 & 2183 & 36 & 90 \\
\hline 65 & 318 & 2 & 4 & 52 & 119 & 2.084 & 0.9 & 0.1633 & 0.50 & 2490 & 17 & 2527 & 36 & 101 \\
\hline 66 & - & 9 & 25 & 210 & 747 & 3.283 & 0.8 & 0.1099 & 0.50 & 1797 & 18 & 1714 & 23 & 95 \\
\hline 68 & - & 8 & 16 & 192 & 459 & 2.239 & 0.8 & 0.1620 & 0.50 & 2477 & 17 & 2380 & 31 & 96 \\
\hline 69 & - & 15 & 42 & 354 & 1254 & 3.266 & 0.8 & 0.1253 & 0.50 & 2033 & 18 & 1722 & 24 & 85 \\
\hline 70 & - & 10 & 30 & 238 & 887 & 3.419 & 1.0 & 0.1258 & 0.50 & 2040 & 18 & 1654 & 30 & 81 \\
\hline 71 & - & 6 & 17 & 156 & 514 & 3.042 & 0.8 & 0.1140 & 0.50 & 1864 & 18 & 1832 & 25 & 98 \\
\hline 72 & - & 4 & 8 & 103 & 242 & 2.190 & 0.8 & 0.1636 & 0.50 & 2493 & 17 & 2425 & 31 & 97 \\
\hline 73 & - & 17 & 34 & 406 & 1019 & 2.294 & 0.8 & 0.1614 & 0.50 & 2470 & 17 & 2332 & 31 & 94 \\
\hline 74 & - & 6 & 18 & 157 & 530 & 3.088 & 0.8 & 0.1128 & 0.50 & 1844 & 18 & 1808 & 24 & 98 \\
\hline 75 & - & 2 & 5 & 37 & 135 & 3.365 & 0.8 & 0.1093 & 0.71 & 1787 & 26 & 1677 & 24 & 94 \\
\hline 76 & - & 5 & 48 & 110 & 1433 & 11.658 & 0.8 & 0.0573 & 0.50 & 501 & 22 & 531 & 8 & 106 \\
\hline A & - & 5 & 13 & 89 & 15 & 3.135 & 0.9 & 0.1131 & 0.50 & 1850 & 9 & 1785 & 28 & 96 \\
\hline B & - & 2 & 5 & 28 & 5 & 3.714 & 1.2 & 0.1072 & 0.73 & 1753 & 27 & 1537 & 33 & 88 \\
\hline C & - & 2 & 3 & 26 & 3 & 2.370 & 0.9 & 0.1612 & 0.50 & 2469 & 17 & 2269 & 34 & 92 \\
\hline $\mathrm{E}$ & - & 7 & 20 & 120 & 23 & 3.557 & 1.5 & 0.1081 & 0.50 & 1768 & 9 & 1597 & 42 & 90 \\
\hline G & - & 5 & 11 & 77 & 13 & 3.167 & 0.9 & 0.1117 & 0.50 & 1827 & 10 & 1769 & 27 & 97 \\
\hline $\mathrm{H}$ & - & 3 & 8 & 53 & 9 & 3.177 & 0.9 & 0.1134 & 0.50 & 1854 & 14 & 1764 & 27 & 95 \\
\hline $\mathrm{J}$ & - & 6 & 10 & 99 & 11 & 2.118 & 0.8 & 0.1666 & 0.50 & 2524 & 6 & 2493 & 33 & 99 \\
\hline $\mathrm{K}$ & - & 2 & 6 & 36 & 6 & 3.238 & 0.8 & 0.1120 & 0.50 & 1833 & 18 & 1735 & 24 & 95 \\
\hline $\mathrm{L}$ & - & 1 & 4 & 23 & 4 & 3.351 & 0.9 & 0.1107 & 0.76 & 1811 & 28 & 1684 & 27 & 93 \\
\hline $\mathrm{N}$ & - & 7 & 16 & 112 & 18 & 3.042 & 0.9 & 0.1176 & 0.50 & 1920 & 7 & 1832 & 30 & 95 \\
\hline $\mathrm{O}$ & - & 3 & 8 & 45 & 9 & 3.815 & 1.1 & 0.1028 & 0.52 & 1675 & 19 & 1501 & 29 & 90 \\
\hline $\mathrm{P}$ & - & 19 & 43 & 303 & 48 & 2.910 & 1.5 & 0.1122 & 0.50 & 1836 & 4 & 1904 & 48 & 104 \\
\hline Q & - & 7 & 15 & 111 & 17 & 2.905 & 1.2 & 0.1146 & 0.50 & 1874 & 7 & 1907 & 41 & 102 \\
\hline
\end{tabular}


Table 6 (Continued)

\begin{tabular}{|c|c|c|c|c|c|c|c|c|c|c|c|c|c|c|}
\hline Spot & $204 \mathrm{~Pb}$ (cps) & ${ }^{206} \mathrm{~Pb}(\mathrm{mV})$ & ${ }^{238} \mathrm{U}(\mathrm{mV})$ & $\mathrm{Pb}(\mathrm{ppm})$ & $\mathrm{U}(\mathrm{ppm})$ & ${ }^{238} \mathrm{U} /{ }^{206} \mathrm{pb}$ & ls $\%$ & ${ }^{207} \mathrm{pb} /{ }^{206} \mathrm{pb}$ & $1 s \%$ & ${ }^{207} \mathrm{pb} /{ }^{206} \mathrm{pb}$ & $2 \mathrm{~s}$ abs & ${ }^{206} \mathrm{~Pb} /{ }^{238} \mathrm{U}$ & $2 \mathrm{~s}$ abs & $\% \mathrm{C}$ \\
\hline $\mathrm{T}$ & - & 3 & 8 & 49 & 9 & 3.351 & 0.8 & 0.1178 & 0.50 & 1923 & 14 & 1683 & 25 & 88 \\
\hline $\mathrm{U}$ & - & 3 & 6 & 49 & 7 & 2.501 & 1.9 & 0.1568 & 0.50 & 2422 & 11 & 2169 & 69 & 90 \\
\hline V & - & 1 & 2 & 14 & 2 & 2.477 & 1.3 & 0.1594 & 0.88 & 2449 & 30 & 2186 & 46 & 89 \\
\hline w & - & 10 & 22 & 162 & 25 & 2.872 & 1.3 & 0.1327 & 0.50 & 2134 & 4 & 1926 & 42 & 90 \\
\hline $\mathrm{X}$ & - & 5 & 9 & 75 & 10 & 2.512 & 0.9 & 0.1581 & 0.50 & 2436 & 7 & 2160 & 33 & 89 \\
\hline $\mathrm{Y}$ & - & 6 & 17 & 104 & 19 & 3.411 & 1.2 & 0.1105 & 0.50 & 1808 & 8 & 1657 & 36 & 92 \\
\hline$z$ & - & 3 & 9 & 53 & 11 & 3.677 & 0.9 & 0.1075 & 0.50 & 1757 & 14 & 1551 & 24 & 88 \\
\hline $\mathrm{AA}$ & - & 19 & 45 & 302 & 50 & 3.045 & 1.2 & 0.1140 & 0.50 & 1865 & 5 & 1831 & 37 & 98 \\
\hline $\mathrm{AB}$ & - & 4 & 6 & 61 & 7 & 2.061 & 0.9 & 0.1773 & 0.50 & 2628 & 7 & 2550 & 38 & 97 \\
\hline$A C$ & - & 2 & 6 & 40 & 7 & 3.033 & 0.8 & 0.1139 & 0.50 & 1863 & 16 & 1837 & 25 & 99 \\
\hline $\mathrm{AD}$ & - & 2 & 6 & 38 & 6 & 3.135 & 0.9 & 0.1125 & 0.52 & 1841 & 19 & 1785 & 29 & 97 \\
\hline $\mathrm{AF}$ & - & 3 & 9 & 52 & 10 & 3.561 & 1.0 & 0.1125 & 0.50 & 1840 & 13 & 1595 & 28 & 87 \\
\hline $\mathrm{AH}$ & - & 10 & 14 & 155 & 15 & 1.852 & 0.9 & 0.2383 & 0.50 & 3109 & 7 & 2783 & 38 & 90 \\
\hline $\mathrm{Al}$ & - & 4 & 10 & 63 & 11 & 3.158 & 0.8 & 0.1121 & 0.50 & 1834 & 13 & 1774 & 25 & 97 \\
\hline AJ & - & 3 & 5 & 52 & 6 & 2.130 & 0.8 & 0.1638 & 0.50 & 2495 & 10 & 2481 & 34 & 99 \\
\hline
\end{tabular}

euhedral to subhedral tabular grains with well preserved crystal terminations, to brown strongly altered, mechanically rounded fractured grains and angular grain fragments (Fig. 9a, Table 2). In $\mathrm{CL}$, the clear zircon are high $\mathrm{U}$, zoned grains similar to those found in the leucosomes of the Neoarchaean-Early Palaeoproterozoic migmatitic orthogneisses of the Betsiboka Suite of the Antananarivo Craton (CGS, 2009b). Most of the remainder of the zircon have moderate U contents with concentric zoning. Several of the grains have thin low $\mathrm{U}$ metamorphic growth rims.

Sixty-two spots were analysed on 60 grains (Table 7) by SHRIMP. Of these, 22 were more than 5\% discordant (Fig. 10a). Assessment of "concordant' data indicates a mean uncertainty of the data point common- $\mathrm{Pb}$ corrected ${ }^{207} \mathrm{~Pb} /{ }^{206} \mathrm{~Pb}$ ages of $49 \mathrm{Ma}(2 \sigma)$ and a histogram bin width efficiency of $75.9 \%$ (at 80 Ma bin width). The prob-
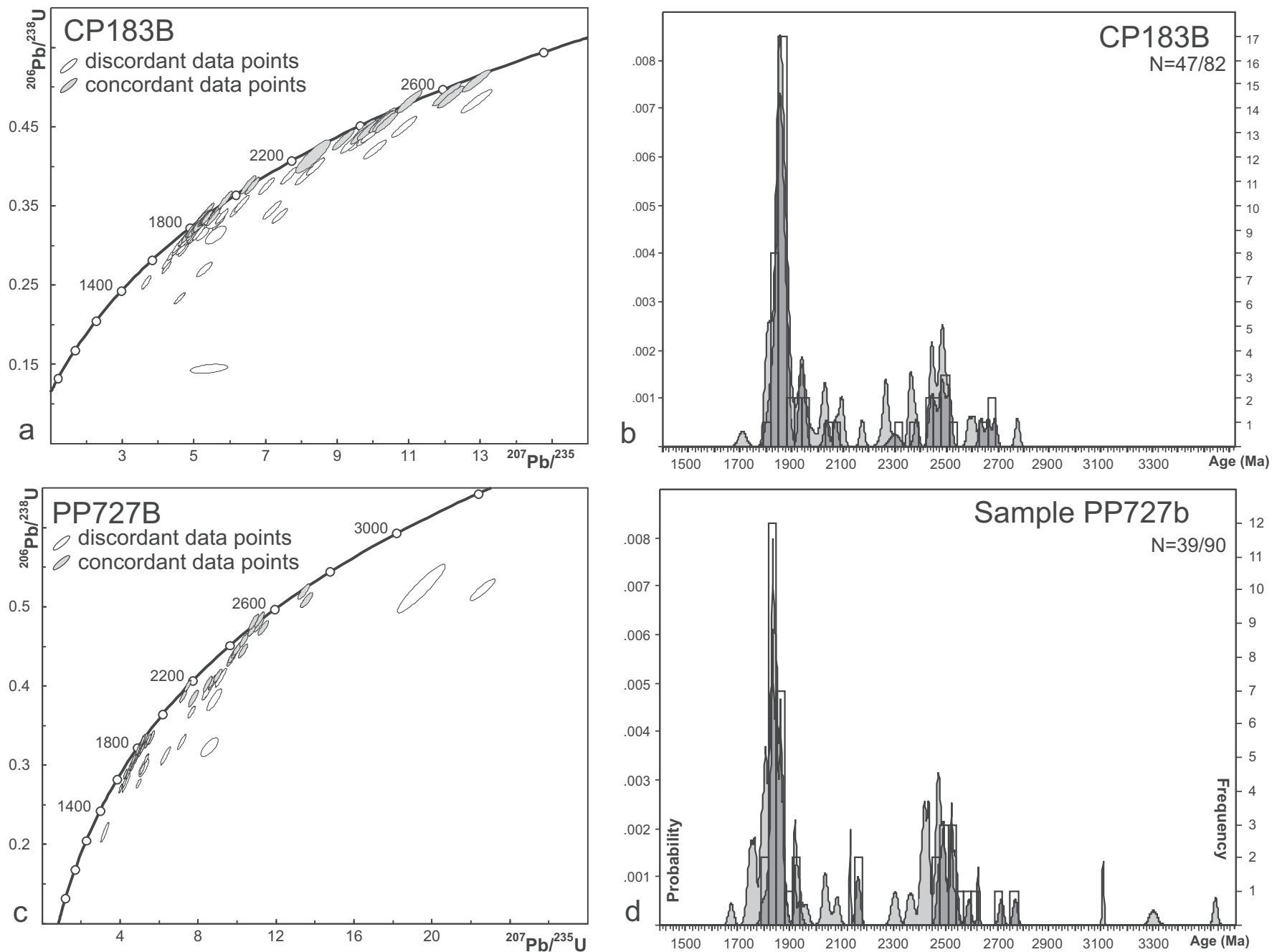

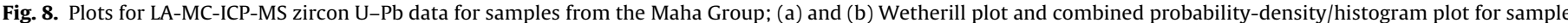

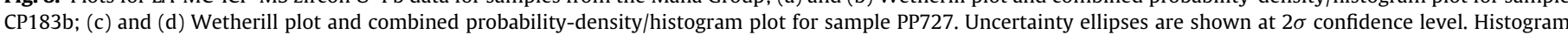
bin-size is 40 million years for CP183b and 30 million years for PP727 (only $100 \pm 5 \%$ concordant data are shown in the histogram). 

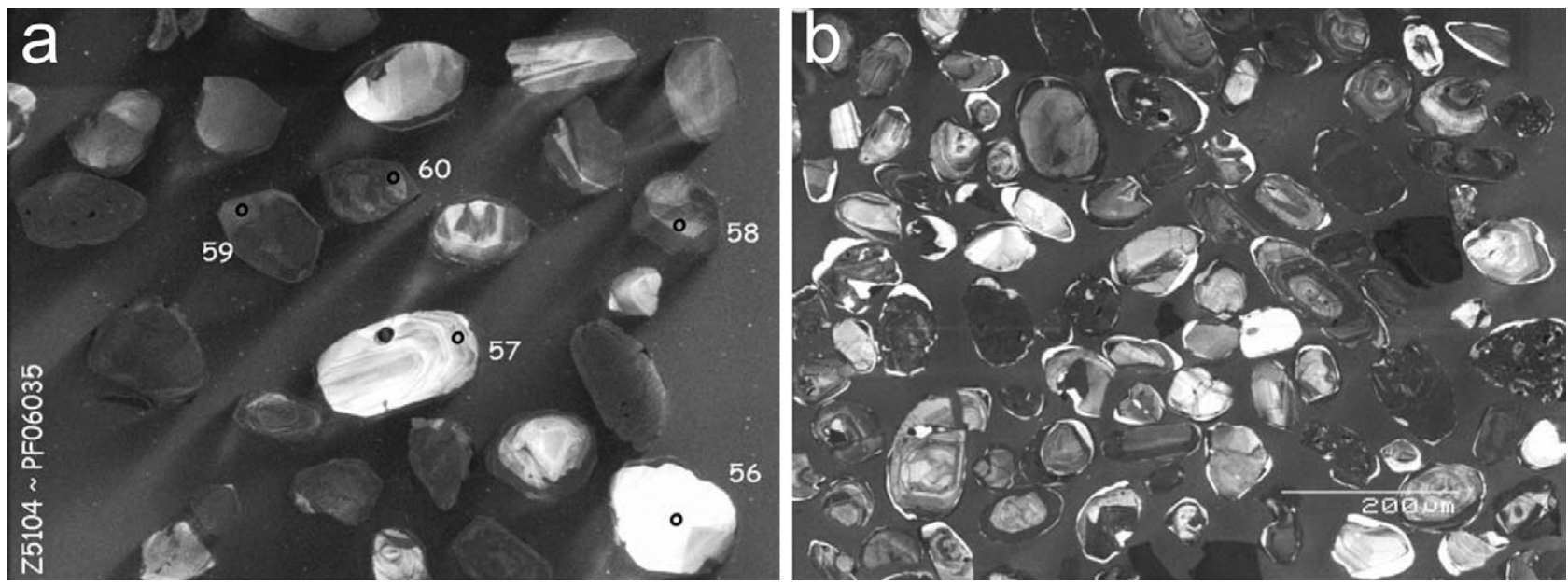

Fig. 9. Cathodo-luminescence imagery of selected zircon grains from samples of the Itremo Group; sample PF06035 (a) and sample PR06088 (b).

ability density distribution indicates age maxima at: 3040, 3000, 2770, 2700, 2610, 2500, 2420, 2170, 2070, 2000, 1920, 1860, 1780, 1470 and $800 \mathrm{Ma}$ rounded to the nearest $10 \mathrm{Ma}$ (Fig. 10b). Maxima within uncertainty define age ranges of 3040-3000, 2770-2700,
2500-2420 and 2070-1780 Ma. The largest mode is that at $2500 \mathrm{Ma}$ with 10 of the 40 concordant data points. Material at $1800-1900 \mathrm{Ma}$ is present but appears more subordinate, but due to the lack of data points for this sample quantitative proportion assessments
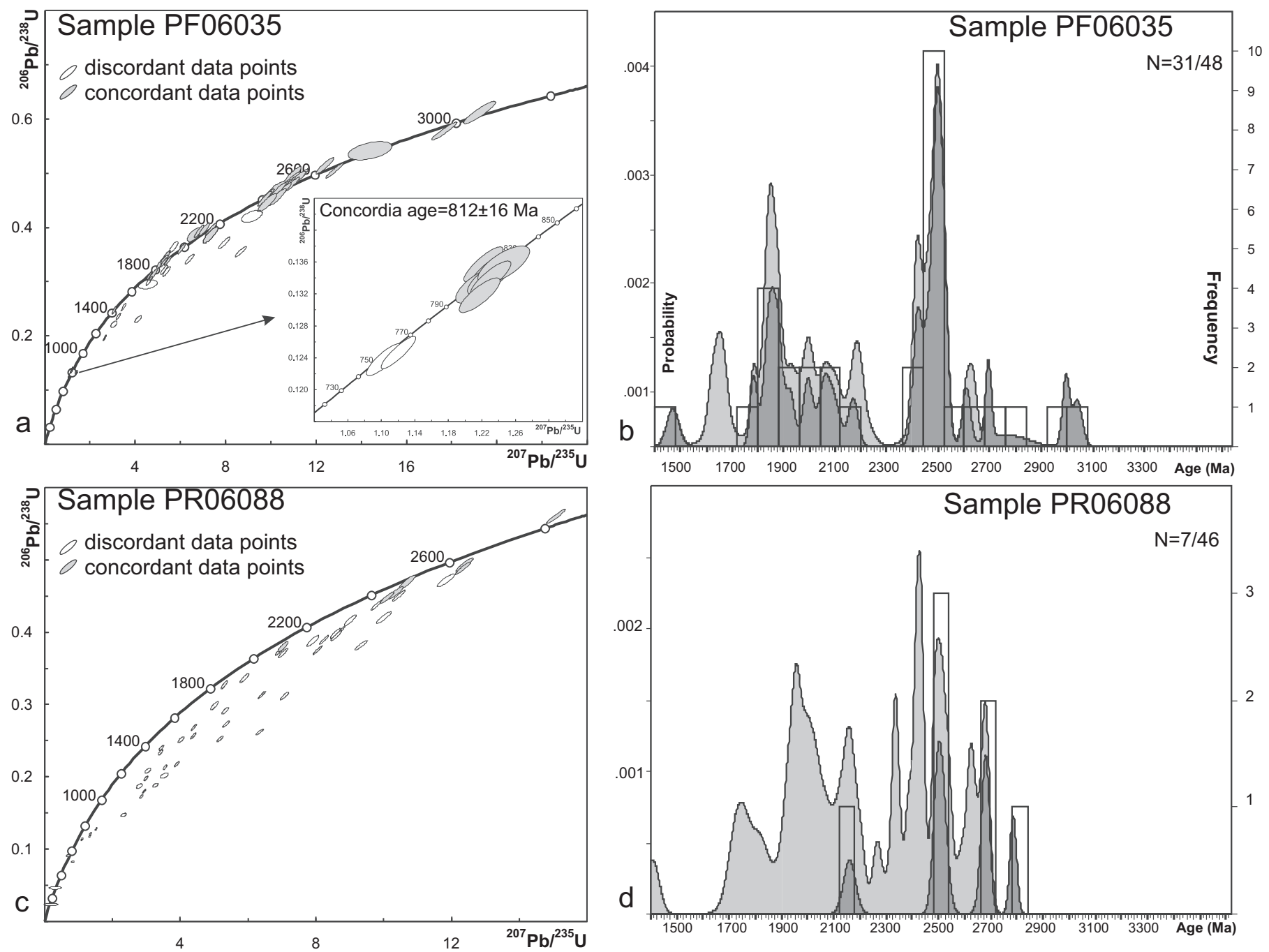

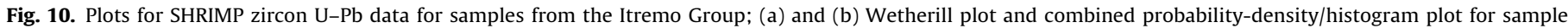

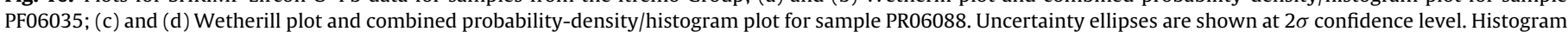
bin-size is 80 million years for PF06035 and 60 million years for PR06088 (only $100 \pm 5 \%$ concordant data are shown in the histogram). 
Table 7

Zircon U-Pb SHRIMP data for sample PF06035.

\begin{tabular}{|c|c|c|c|c|c|c|c|c|c|}
\hline Spot name & $f_{206}(\%)$ & $\mathrm{U}(\mathrm{ppm})$ & Th (ppm) & ${ }^{232} \mathrm{Th} /{ }^{238} \mathrm{U}(\mathrm{ppm})$ & ${ }^{238} \mathrm{U} /{ }^{206} \mathrm{pb}(1 \sigma$ abs err $)$ & ${ }^{207} \mathrm{pb} /{ }^{206} \mathrm{pb}(1 \sigma$ abs err $)$ & $\begin{array}{l}{ }^{206} \mathrm{pb} /{ }^{238} \mathrm{U} \text { age } \\
(2 \sigma \text { abs err }(\mathrm{Ma}))\end{array}$ & $\begin{array}{l}{ }^{207} \mathrm{~Pb} /{ }^{206} \mathrm{~Pb} \text { age } \\
(2 \sigma \text { abs err }(\mathrm{Ma}))\end{array}$ & $\mathrm{C} \%$ \\
\hline $35-1.1$ & 0.06 & 570 & 128 & 0.23 & $8.0917 \pm 0.0904$ & $0.06397 \pm 0.00075$ & $752 \pm 15$ & $766 \pm 28$ & 98 \\
\hline $35-1.2$ & 0.11 & 45 & 28 & 0.64 & $2.6131 \pm 0.0445$ & $0.13494 \pm 0.00259$ & $2097 \pm 56$ & $2212 \pm 33$ & 95 \\
\hline $35-10.1$ & 0.08 & 100 & 65 & 0.67 & $3.0125 \pm 0.0418$ & $0.11040 \pm 0.00193$ & $1852 \pm 41$ & $1842 \pm 26$ & 101 \\
\hline $35-11.1$ & 0.01 & 120 & 83 & 0.72 & $1.7368 \pm 0.0227$ & $0.22068 \pm 0.00165$ & $2935 \pm 57$ & $2995 \pm 13$ & 98 \\
\hline $35-12.1$ & - & 233 & 159 & 0.71 & $2.0294 \pm 0.0256$ & $0.16625 \pm 0.00158$ & $2583 \pm 50$ & $2522 \pm 15$ & 102 \\
\hline $35-13.1$ & 0.08 & 1347 & 309 & 0.24 & $8.3286 \pm 0.0901$ & $0.06799 \pm 0.00066$ & $731 \pm 14$ & $873 \pm 23$ & 84 \\
\hline $35-14.1$ & - & 750 & 177 & 0.24 & $7.3638 \pm 0.0821$ & $0.06618 \pm 0.00073$ & $820 \pm 17$ & $785 \pm 27$ & 104 \\
\hline $35-14.2$ & - & 313 & 162 & 0.54 & $2.8884 \pm 0.0353$ & $0.11351 \pm 0.00130$ & $1916 \pm 38$ & $1852 \pm 22$ & 103 \\
\hline $35-15.1$ & 0.15 & 1043 & 201 & 0.20 & $8.9853 \pm 0.0983$ & $0.06501 \pm 0.00070$ & $682 \pm 14$ & $841 \pm 29$ & 81 \\
\hline $35-16.1$ & 0.00 & 416 & 167 & 0.41 & $2.3902 \pm 0.0275$ & $0.15776 \pm 0.00285$ & $2256 \pm 42$ & $2444 \pm 58$ & 92 \\
\hline $35-17.1$ & - & 166 & 107 & 0.67 & $2.1419 \pm 0.0284$ & $0.16339 \pm 0.00168$ & $2472 \pm 50$ & $2499 \pm 18$ & 99 \\
\hline $35-18.1$ & 0.03 & 426 & 64 & 0.16 & $3.9845 \pm 0.0450$ & $0.10092 \pm 0.00076$ & $1445 \pm 29$ & $1659 \pm 20$ & 87 \\
\hline $35-19.1$ & - & 215 & 116 & 0.56 & $2.5301 \pm 0.0320$ & $0.13655 \pm 0.00142$ & $2145 \pm 43$ & $2170 \pm 19$ & 99 \\
\hline $35-2.1$ & 0.26 & 466 & 230 & 0.51 & $3.2976 \pm 0.0453$ & $0.14360 \pm 0.00698$ & $1656 \pm 34$ & $1858 \pm 126$ & 89 \\
\hline $35-20.1$ & 0.04 & 493 & 95 & 0.20 & $3.0968 \pm 0.0343$ & $0.12833 \pm 0.00088$ & $1789 \pm 34$ & $1957 \pm 21$ & 91 \\
\hline $35-21.1$ & - & 506 & 40 & 0.08 & $2.9607 \pm 0.0325$ & $0.11419 \pm 0.00084$ & $1876 \pm 35$ & $1866 \pm 26$ & 101 \\
\hline $35-23.1$ & 0.02 & 666 & 158 & 0.25 & $7.4752 \pm 0.0843$ & $0.06605 \pm 0.00083$ & $810 \pm 17$ & $828 \pm 29$ & 98 \\
\hline $35-24.1$ & - & 284 & 29 & 0.11 & $2.7642 \pm 0.0321$ & $0.11426 \pm 0.00094$ & $1991 \pm 39$ & $1873 \pm 28$ & 106 \\
\hline $35-25.1$ & 0.02 & 196 & 116 & 0.61 & $2.1388 \pm 0.0275$ & $0.15962 \pm 0.00153$ & $2475 \pm 49$ & $2460 \pm 17$ & 101 \\
\hline $35-26.1$ & & 286 & 130 & 0.47 & $2.9726 \pm 0.0376$ & $0.12819 \pm 0.00289$ & $1886 \pm 38$ & $2193 \pm 18$ & 86 \\
\hline $35-26.2$ & - & 120 & 55 & 0.47 & $1.8504 \pm 0.0253$ & $0.19316 \pm 0.00484$ & $2785 \pm 59$ & $2768 \pm 80$ & 101 \\
\hline $35-27.1$ & - & 206 & 278 & 1.39 & $2.0452 \pm 0.0287$ & $0.16679 \pm 0.00304$ & $2565 \pm 50$ & $2520 \pm 20$ & 102 \\
\hline $35-28.1$ & 0.07 & 1087 & 105 & 0.10 & $7.1415 \pm 0.0772$ & $0.06751 \pm 0.00065$ & $849 \pm 17$ & $984 \pm 29$ & 86 \\
\hline $35-29.1$ & - & 128 & 72 & 0.59 & $2.0582 \pm 0.0282$ & $0.16246 \pm 0.00183$ & $2555 \pm 54$ & $2490 \pm 20$ & 103 \\
\hline $35-3.1$ & 0.17 & 206 & 89 & 0.45 & $3.1387 \pm 0.0381$ & $0.12778 \pm 0.00123$ & $1776 \pm 36$ & $2012 \pm 24$ & 88 \\
\hline $35-30.1$ & 0.29 & 501 & 199 & 0.41 & $2.8477 \pm 0.0334$ & $0.17170 \pm 0.00141$ & $1952 \pm 37$ & $2636 \pm 15$ & 74 \\
\hline $35-31.1$ & - & 585 & 146 & 0.26 & $7.4631 \pm 0.0849$ & $0.06639 \pm 0.00083$ & $811 \pm 17$ & $824 \pm 39$ & 98 \\
\hline $35-32.1$ & - & 645 & 152 & 0.24 & $7.4224 \pm 0.0861$ & $0.06571 \pm 0.00079$ & $815 \pm 17$ & $810 \pm 29$ & 101 \\
\hline $35-33.1$ & - & 427 & 275 & 0.67 & $2.0849 \pm 0.0246$ & $0.16354 \pm 0.00135$ & $2525 \pm 46$ & $2489 \pm 13$ & 101 \\
\hline $35-34.1$ & - & 489 & 58 & 0.12 & $7.3839 \pm 0.0869$ & $0.06564 \pm 0.00068$ & $820 \pm 18$ & $827 \pm 48$ & 99 \\
\hline $35-35.1$ & - & 195 & 154 & 0.81 & $2.1919 \pm 0.0289$ & $0.15618 \pm 0.00189$ & $2424 \pm 48$ & $2419 \pm 17$ & 100 \\
\hline $35-36.1$ & - & 227 & 142 & 0.65 & $2.0888 \pm 0.0260$ & $0.16623 \pm 0.00149$ & $2521 \pm 48$ & $2518 \pm 15$ & 100 \\
\hline $35-37.1$ & - & 68 & 29 & 0.43 & $2.2596 \pm 0.0374$ & $0.15791 \pm \pm 0.00193$ & $2369 \pm 62$ & $2467 \pm 27$ & 96 \\
\hline $35-38.1$ & - & 191 & 123 & 0.66 & $1.9500 \pm 0.0252$ & $0.17531 \pm 0.00163$ & $2669 \pm 52$ & $2609 \pm 16$ & 102 \\
\hline $35-39.1$ & - & 663 & 154 & 0.24 & $7.5963 \pm 0.0856$ & $0.06617 \pm 0.00078$ & $798 \pm 16$ & $838 \pm 31$ & 95 \\
\hline $35-4.1$ & 0.02 & 304 & 94 & 0.32 & $2.9996 \pm 0.0345$ & $0.11402 \pm 0.00086$ & $1857 \pm 36$ & $1882 \pm 15$ & 99 \\
\hline $35-4.2$ & 0.04 & 159 & 94 & 0.61 & $3.2170 \pm 0.0484$ & $0.11280 \pm 0.00197$ & $1744 \pm 42$ & $1839 \pm 26$ & 95 \\
\hline $35-40.1$ & - & 439 & 89 & 0.21 & $4.4178 \pm 0.0524$ & $0.12293 \pm 0.00159$ & $1327 \pm 27$ & $2123 \pm 33$ & 63 \\
\hline $35-41.1$ & 0.00 & 308 & 112 & 0.38 & $2.9721 \pm 0.0355$ & $0.11338 \pm 0.00104$ & $1869 \pm 37$ & $1847 \pm 19$ & 101 \\
\hline $35-42.1$ & - & 377 & 50 & 0.14 & $2.7865 \pm 0.0316$ & $0.12263 \pm 0.00066$ & $1977 \pm 38$ & $1994 \pm 17$ & 99 \\
\hline $35-43.1$ & - & 102 & 18 & 0.19 & $2.5979 \pm 0.0363$ & $0.12391 \pm 0.00172$ & $2101 \pm 49$ & $2029 \pm 49$ & 104 \\
\hline $35-44.1$ & - & 512 & 62 & 0.13 & $4.5628 \pm 0.0508$ & $0.10029 \pm 0.00166$ & $1280 \pm 25$ & $1658 \pm 56$ & 77 \\
\hline $35-45.1$ & 0.07 & 1117 & 129 & 0.12 & $7.7537 \pm 0.0846$ & $0.07255 \pm 0.00180$ & $788 \pm 16$ & $1185 \pm 57$ & 67 \\
\hline $35-46.1$ & 0.01 & 691 & 73 & 0.11 & $4.2870 \pm 0.0464$ & $0.10057 \pm 0.00080$ & $1354 \pm 26$ & $1660 \pm 22$ & 82 \\
\hline $35-47.1$ & - & 85 & 34 & 0.41 & $1.6381 \pm 0.0236$ & $0.22676 \pm 0.00166$ & $3076 \pm 68$ & $3039 \pm 20$ & 101 \\
\hline $35-48.1$ & 0.22 & 1389 & 56 & 0.04 & $7.1757 \pm 0.0756$ & $0.07089 \pm 0.00056$ & $841 \pm 16$ & $957 \pm 26$ & 88 \\
\hline $35-49.1$ & - & 281 & 200 & 0.73 & $2.1250 \pm 0.0265$ & $0.16006 \pm 0.00234$ & $2485 \pm 47$ & $2452 \pm 39$ & 101 \\
\hline $35-5.1$ & 0.00 & 67 & 93 & 1.42 & $2.2112 \pm 0.0371$ & $0.15975 \pm 0.00397$ & $2416 \pm 56$ & $2501 \pm 22$ & 97 \\
\hline $35-50.1$ & - & 675 & 18 & 0.03 & $2.9682 \pm 0.0317$ & $0.11838 \pm 0.00058$ & $1871 \pm 35$ & $1925 \pm 17$ & 97 \\
\hline $35-53.1$ & - & 242 & 133 & 0.57 & $2.5566 \pm 0.0322$ & $0.12716 \pm 0.00142$ & $2128 \pm 43$ & $2059 \pm 20$ & 103 \\
\hline $35-54.1$ & - & 274 & 118 & 0.45 & $2.2135 \pm 0.0301$ & $0.15672 \pm 0.00130$ & $2403 \pm 52$ & $2419 \pm 15$ & 99 \\
\hline $35-55.1$ & 0.06 & 691 & 86 & 0.13 & $5.1859 \pm 0.0581$ & $0.09532 \pm 0.00070$ & $1142 \pm 23$ & $1624 \pm 18$ & 70 \\
\hline $35-56.1$ & - & 105 & 58 & 0.56 & $2.0202 \pm 0.0289$ & $0.16105 \pm 0.00174$ & $2591 \pm 57$ & $2463 \pm 22$ & 105 \\
\hline $35-57.1$ & 0.04 & 152 & 90 & 0.61 & $2.5337 \pm 0.0344$ & $0.12922 \pm 0.00175$ & $2146 \pm 46$ & $2097 \pm 23$ & 102 \\
\hline $35-58.1$ & - & 484 & 49 & 0.10 & $1.9853 \pm 0.0233$ & $0.18507 \pm 0.00067$ & $2629 \pm 50$ & $2695 \pm 11$ & 98 \\
\hline $35-59.1$ & - & 341 & 57 & 0.17 & $7.5265 \pm 0.0902$ & $0.06488 \pm 0.00094$ & $806 \pm 18$ & $819 \pm 45$ & 98 \\
\hline $35-6.1$ & 0.02 & 203 & 183 & 0.93 & $2.1033 \pm 0.0267$ & $0.16352 \pm 0.00197$ & $2509 \pm 47$ & $2498 \pm 12$ & 100 \\
\hline $35-60.1$ & - & 712 & 259 & 0.38 & $3.2405 \pm 0.0362$ & $0.10893 \pm 0.00091$ & $1734 \pm 32$ & $1783 \pm 13$ & 97 \\
\hline $35-7.1$ & 0.05 & 162 & 152 & 0.97 & $2.7142 \pm 0.0364$ & $0.15380 \pm 0.00230$ & $2027 \pm 41$ & $2415 \pm 17$ & 84 \\
\hline $35-8.1$ & 0.06 & 399 & 58 & 0.15 & $3.3433 \pm 0.0369$ & $0.11309 \pm 0.00065$ & $1686 \pm 32$ & $1843 \pm 19$ & 92 \\
\hline $35-9.1$ & 0.00 & 762 & 186 & 0.25 & $8.0321 \pm 0.0896$ & $0.06485 \pm 0.00070$ & $757 \pm 15$ & $783 \pm 23$ & 97 \\
\hline $35-9.2$ & 0.03 & 209 & 127 & 0.63 & $4.0878 \pm 0.0512$ & $0.08986 \pm 0.00162$ & $1414 \pm 29$ & $1470 \pm 24$ & 96 \\
\hline
\end{tabular}

Analyses were conducted during one session, with standard analyses yielding a $2 \sigma$ error of the mean of $0.28 \% . f_{206}=$ the proportion of common ${ }^{206} \mathrm{~Pb}$ in the total ${ }^{206} \mathrm{~Pb}$; $\mathrm{Th} / \mathrm{U}={ }^{232} \mathrm{Th} /{ }^{238} \mathrm{U} ; \mathrm{C} \%=$ concordance; all ratios and ages are corrected for common Pb using measured ${ }^{204} \mathrm{~Pb}$ and composition appropriate to the age of the zircon (Stacey and Kramers, 1975).

are limited. The oldest concordant grain is $3039 \pm 40 \mathrm{Ma}(2 \sigma)$. One analysis on a core of a complex zircon yielded a ${ }^{207} \mathrm{~Pb} / 206 \mathrm{~Pb}$ age of $1470 \pm 48 \mathrm{Ma}(2 \sigma, 96 \%$ concordance $)$ with a second spot on a high uranium rim (metamorphic) overgrowth giving a ${ }^{206} \mathrm{~Pb} /{ }^{238} \mathrm{U}$ age of $757 \pm 30 \mathrm{Ma}(2 \sigma, 97 \%$ concordance $)$. We interpret this core analysis to either reflect mixing between an older core and the younger rim, or to perhaps date the maximum age of deposition. Apart from this single analysis, the youngest concordant core ${ }^{207} \mathrm{~Pb} /{ }^{206} \mathrm{~Pb}$ age was recorded at $1783 \pm 26 \mathrm{Ma}(2 \sigma, 97 \%$ concordance), constraining the maximum age of deposition for the sample. The clear high $U$ zoned zircons yielded ages between 2450 and $2500 \mathrm{Ma}$ and confirm that the Betsiboka Suite orthogneisses (Antananarivo Domain) represent their most probable source. 
Table 8

Zircon U-Pb SHRIMP data for sample PR06088.

\begin{tabular}{|c|c|c|c|c|c|c|c|c|c|}
\hline \multirow[t]{2}{*}{ Spot name } & \multirow[t]{2}{*}{$f_{206}(\%)$} & \multirow[t]{2}{*}{$\mathrm{U}(\mathrm{ppm})$} & \multirow[t]{2}{*}{ Th (ppm) } & \multirow[t]{2}{*}{${ }^{232} \mathrm{Tn} /{ }^{238} \mathrm{U}(\mathrm{ppm})$} & \multirow{2}{*}{$\frac{{ }^{238} \mathrm{U} /{ }^{206} \mathrm{~Pb}}{1 \sigma \mathrm{abs} \text { err }}$} & \multirow[t]{2}{*}{${ }^{207} \mathrm{~Pb} /{ }^{206} \mathrm{~Pb}$} & \multirow{2}{*}{$\frac{{ }^{206} \mathrm{~Pb} /{ }^{238} \mathrm{U} \text { age }}{1 \sigma \text { abs err }}$} & \multirow[t]{2}{*}{${ }^{207} \mathrm{~Pb} /{ }^{206} \mathrm{~Pb}$ age } & \multirow[t]{2}{*}{$\mathrm{C} \%$} \\
\hline & & & & & & & & & \\
\hline PR06088-1.1 & 0.05 & 174 & 59 & 0.35 & $2.6354 \pm 0.0321$ & $0.17384 \pm 0.00124$ & $2081 \pm 41$ & $2631 \pm 16$ & 79 \\
\hline PR06088-2.1 & - & 545 & 181 & 0.34 & $2.5697 \pm 0.0282$ & $0.15380 \pm 0.00083$ & $2119 \pm 38$ & $2387 \pm 12$ & 89 \\
\hline PR06088-3.1 & 0.02 & 355 & 235 & 0.68 & $2.2919 \pm 0.0275$ & $0.16209 \pm 0.00143$ & $2336 \pm 43$ & $2485 \pm 12$ & 94 \\
\hline PR06088-4.1 & - & 143 & 70 & 0.51 & $2.6439 \pm 0.0353$ & $0.13214 \pm 0.00159$ & $2073 \pm 44$ & $2160 \pm 23$ & 96 \\
\hline PR06088-5.1 & - & 139 & 31 & 0.23 & $2.1253 \pm 0.0269$ & $0.18068 \pm 0.00135$ & $2489 \pm 51$ & $2672 \pm 22$ & 93 \\
\hline PR06088-6.1 & 0.51 & 491 & 75 & 0.16 & $4.1989 \pm 0.0469$ & $0.10255 \pm 0.00080$ & $1381 \pm 27$ & $1719 \pm 28$ & 80 \\
\hline PR06088-7.1 & 0.55 & 865 & 361 & 0.43 & $5.4103 \pm 0.0622$ & $0.11884 \pm 0.00209$ & $1103 \pm 22$ & $2067 \pm 42$ & 53 \\
\hline PR06088-8.1 & 0.14 & 158 & 89 & 0.58 & $3.3967 \pm 0.0455$ & $0.11436 \pm 0.00202$ & $1677 \pm 36$ & $1996 \pm 27$ & 84 \\
\hline PR06088-9.1 & 0.25 & 1501 & 233 & 0.16 & $7.9340 \pm 0.0836$ & $0.08915 \pm 0.00064$ & $765 \pm 15$ & $1409 \pm 25$ & 54 \\
\hline PR06088-10.1 & 0.03 & 177 & 84 & 0.49 & $2.7082 \pm 0.0345$ & $0.13446 \pm 0.00147$ & $2033 \pm 42$ & $2202 \pm 19$ & 92 \\
\hline PR06088-11.1 & 0.01 & 608 & 274 & 0.47 & $3.1997 \pm 0.0361$ & $0.15016 \pm 0.00100$ & $1751 \pm 33$ & $2335 \pm 11$ & 75 \\
\hline PR06088-12.1 & 0.07 & 83 & 55 & 0.69 & $2.1366 \pm 0.0321$ & $0.16349 \pm 0.00221$ & $2479 \pm 57$ & $2511 \pm 23$ & 99 \\
\hline PR06088-13.1 & 0.14 & 1234 & 247 & 0.21 & $8.6179 \pm 0.0924$ & $0.08405 \pm 0.00101$ & $708 \pm 14$ & $1307 \pm 40$ & 54 \\
\hline PR06088-13.2 & 0.04 & 136 & 82 & 0.62 & $2.0338 \pm 0.0277$ & $0.18098 \pm 0.00178$ & $2581 \pm 54$ & $2675 \pm 17$ & 97 \\
\hline PR06088-14.1 & 0.00 & 226 & 78 & 0.36 & $3.0664 \pm 0.0374$ & $0.11785 \pm 0.00113$ & $1820 \pm 37$ & $1929 \pm 19$ & 94 \\
\hline PR06088-15.1 & 0.02 & 504 & 359 & 0.74 & $2.4932 \pm 0.0293$ & $0.15675 \pm 0.00145$ & $2176 \pm 40$ & $2433 \pm 10$ & 89 \\
\hline PR06088-16.1 & 0.03 & 578 & 156 & 0.28 & $2.6711 \pm 0.0294$ & $0.15655 \pm 0.00071$ & $2049 \pm 38$ & $2415 \pm 10$ & 85 \\
\hline PR06088-17.1 & 0.84 & 598 & 182 & 0.31 & $4.7167 \pm 0.0547$ & $0.11403 \pm 0.00171$ & $1262 \pm 25$ & $2119 \pm 25$ & 60 \\
\hline PR08066-18.1 & - & 210 & 114 & 0.56 & $2.0500 \pm 0.0256$ & $0.18273 \pm 0.00135$ & $2563 \pm 50$ & $2683 \pm 13$ & 96 \\
\hline PR08066-19.1 & 0.52 & 510 & 167 & 0.34 & $4.3284 \pm 0.0496$ & $0.10206 \pm 0.00115$ & $1347 \pm 26$ & $1752 \pm 28$ & 77 \\
\hline PR08066-20.1 & 0.80 & 635 & 175 & 0.28 & $5.1088 \pm 0.0572$ & $0.10872 \pm 0.00122$ & $1155 \pm 23$ & $1820 \pm 32$ & 63 \\
\hline PR08066-21.1 & 0.00 & 155 & 71 & 0.47 & $2.5892 \pm 0.0356$ & $0.14675 \pm 0.00166$ & $2109 \pm 47$ & $2328 \pm 25$ & 91 \\
\hline PR08066-22.1 & 0.46 & 480 & 54 & 0.12 & $3.9913 \pm 0.0439$ & $0.11837 \pm 0.00092$ & $1440 \pm 28$ & $1916 \pm 30$ & 75 \\
\hline PR08066-23.1 & 0.76 & 1192 & 85 & 0.07 & $8.9623 \pm 0.0953$ & $0.07248 \pm 0.00082$ & $683 \pm 14$ & $1027 \pm 47$ & 66 \\
\hline PR08066-24.1 & 1.24 & 915 & 368 & 0.41 & $7.1192 \pm 0.0858$ & $0.08700 \pm 0.00350$ & $875 \pm 17$ & $1924 \pm 70$ & 45 \\
\hline PR08066-25.1 & 0.39 & 324 & 31 & 0.10 & $3.4371 \pm 0.0389$ & $0.13520 \pm 0.00094$ & $1643 \pm 32$ & $2144 \pm 26$ & 77 \\
\hline PR08066-26.1 & 0.02 & 232 & 128 & 0.57 & $2.2227 \pm 0.0273$ & $0.16818 \pm 0.00134$ & $2395 \pm 46$ & $2541 \pm 13$ & 94 \\
\hline PR08066-27.1 & 0.36 & 753 & 169 & 0.23 & $4.7616 \pm 0.0524$ & $0.11591 \pm 0.00109$ & $1237 \pm 24$ & $1993 \pm 22$ & 62 \\
\hline PR08066-28.1 & 5.83 & 1615 & 206 & 0.13 & $12.5480 \pm 0.1526$ & $0.06628 \pm 0.00365$ & $501 \pm 11$ & $1147 \pm 111$ & 44 \\
\hline PR08066-29.1 & 0.19 & 286 & 21 & 0.08 & $8.4916 \pm 0.1041$ & $0.07074 \pm 0.00138$ & $728 \pm 16$ & $1282 \pm 51$ & 57 \\
\hline PR08066-30.1 & 0.55 & 695 & 478 & 0.71 & $5.7984 \pm 0.0720$ & $0.08893 \pm 0.00299$ & $1059 \pm 21$ & $1955 \pm 23$ & 54 \\
\hline PR08066-31.1 & 0.06 & 173 & 90 & 0.54 & $2.9843 \pm 0.0401$ & $0.12608 \pm 0.00172$ & $1866 \pm 40$ & $2066 \pm 24$ & 90 \\
\hline PR08066-32.1 & 0.35 & 628 & 75 & 0.12 & $3.9906 \pm 0.0451$ & $0.14704 \pm 0.00111$ & $1446 \pm 29$ & $2344 \pm 19$ & 62 \\
\hline PR08066-32.2 & 0.77 & 783 & 286 & 0.38 & $3.8708 \pm 0.0436$ & $0.16799 \pm 0.00131$ & $1494 \pm 28$ & $2622 \pm 15$ & 57 \\
\hline PR08066-33.1 & 0.02 & 571 & 73 & 0.13 & $3.7514 \pm 0.0412$ & $0.11827 \pm 0.00065$ & $1526 \pm 29$ & $1957 \pm 15$ & 78 \\
\hline PR08066-34.1 & 0.06 & 122 & 48 & 0.41 & $2.3960 \pm 0.0329$ & $0.16820 \pm 0.00162$ & $2259 \pm 50$ & $2587 \pm 20$ & 87 \\
\hline PR08066-35.1 & 0.74 & 802 & 324 & 0.42 & $5.8810 \pm 0.0671$ & $0.11832 \pm 0.00166$ & $1017 \pm 20$ & $1990 \pm 30$ & 51 \\
\hline PR08066-36.1 & 0.00 & 192 & 142 & 0.76 & $2.2391 \pm 0.0297$ & $0.16234 \pm 0.00190$ & $2384 \pm 48$ & $2496 \pm 17$ & 96 \\
\hline PR08066-37.1 & 0.02 & 204 & 99 & 0.50 & $1.7910 \pm 0.0222$ & $0.19269 \pm 0.00129$ & $2866 \pm 54$ & $2786 \pm 13$ & 103 \\
\hline PR08066-38.1 & 0.03 & 209 & 272 & 1.35 & $2.6834 \pm 0.0402$ & $0.13211 \pm 0.00338$ & $2048 \pm 44$ & $2165 \pm 19$ & 95 \\
\hline PR08066-39.1 & 1.07 & 194 & 45 & 0.24 & $5.1128 \pm 0.0696$ & $0.10770 \pm 0.00274$ & $1176 \pm 27$ & $2078 \pm 62$ & 57 \\
\hline PR08066-40.1 & 0.26 & 553 & 166 & 0.31 & $3.7227 \pm 0.0432$ & $0.13158 \pm 0.00129$ & $1552 \pm 30$ & $2266 \pm 18$ & 68 \\
\hline PR08066-41.1 & 0.23 & 216 & 96 & 0.46 & $2.4081 \pm 0.0297$ & $0.15599 \pm 0.00143$ & $2242 \pm 44$ & $2428 \pm 18$ & 92 \\
\hline PR08066-42.1 & 0.50 & 551 & 200 & 0.38 & $3.9056 \pm 0.0439$ & $0.12748 \pm 0.00097$ & $1466 \pm 28$ & $2029 \pm 20$ & 72 \\
\hline PR08066-43.1 & 2.51 & 400 & 226 & 0.58 & $5.4981 \pm 0.0727$ & $0.09238 \pm 0.00410$ & $1097 \pm 23$ & $1803 \pm 61$ & 61 \\
\hline PR08066-44.1 & 0.07 & 279 & 126 & 0.47 & $3.2067 \pm 0.0442$ & $0.16837 \pm 0.00625$ & $1745 \pm 35$ & $2513 \pm 15$ & 69 \\
\hline PR08066-45.1 & 0.02 & 160 & 132 & 0.85 & $2.2132 \pm 0.0303$ & $0.16114 \pm 0.00226$ & $2413 \pm 50$ & $2513 \pm 20$ & 96 \\
\hline PR08066-46.1 & 0.02 & 349 & 232 & 0.69 & $2.5225 \pm 0.0304$ & $0.15445 \pm 0.00157$ & $2157 \pm 41$ & $2420 \pm 16$ & 89 \\
\hline PR08066-47.1 & 0.16 & 287 & 182 & 0.65 & $2.5443 \pm 0.0314$ & $0.15496 \pm 0.00170$ & $2144 \pm 41$ & $2439 \pm 15$ & 88 \\
\hline PR08066-48.1 & 0.79 & 574 & 287 & 0.52 & $4.8997 \pm 0.0596$ & $0.09477 \pm 0.00192$ & $1213 \pm 25$ & $1759 \pm 52$ & 69 \\
\hline PR08066-49.1 & 13.77 & 36 & 5 & 0.13 & $48.4727 \pm 1.9169$ & $0.04201 \pm 0.02231$ & $137 \pm 16$ & $1083 \pm 2449$ & 13 \\
\hline PR08066-50.1 & 0.74 & 110 & 3 & 0.02 & $11.1629 \pm 0.1590$ & $0.06154 \pm 0.00155$ & $552 \pm 15$ & $577 \pm 197$ & 96 \\
\hline PR08066-51.1 & 20.72 & 140 & 7 & 0.05 & $22.7231 \pm 0.5779$ & $0.05090 \pm 0.01547$ & $279 \pm 17$ & $425 \pm 1556$ & 66 \\
\hline
\end{tabular}

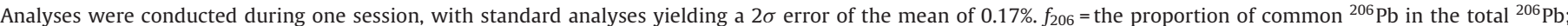

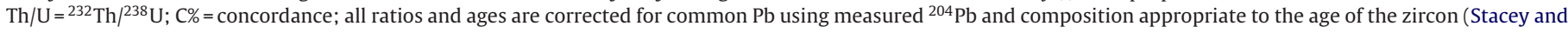
Kramers, 1975).

Six data points from analyses of zircon rims cluster around Concordia and give a concordia age of $812 \pm 16 \mathrm{Ma}$ (Fig. 10a) with two younger (ca. $750 \mathrm{Ma}$ ) near concordant rim ages possibly defining $\mathrm{Pb}$-loss during late-Neoproterozoic reworking.

Quartzite sample PR06088 was collected from a thick quartzite package at the centre of an $\mathrm{F}_{2}$ dome structure near the western border of the Itremo-Ikalamavony Belt. The strongly recrystallised quartzites are slightly feldspathic with some ferruginous layers. The sample yielded two main groups of small (ca. 100-180 $\mu \mathrm{m}$ ) detrital zircons (Table 2, Fig. 9b). Roughly $25 \%$ of the zircons are rounded, subhedral to anhedral, caramel-brown crystals with pitted surfaces. The remaining $75 \%$ are small rounded to subrounded, colourless transparent ovoid crystals, free of inclusions. The $\mathrm{CL}$ images indicate the rock contains a heterogenous array of detrital zircons, but three main morphological groups may be identified (Fig. 9b). The first group represents mechanically rounded fragments of moderate $U$, concentrically zoned, magmatic zircons. The second group represents moderate $U$, concentrically zoned magmatic zircons that are not fractured and the third group is characterised by low $U$ unzoned grains. Most grains have thin, unzoned, light-CL (low U) rims, but only one was wide enough to allow analysis.

The 51 zircon grains analysed by SHRIMP yielded a range of strongly discordant data (Fig. 10c, Table 8). Assessment of "concordant' ( $>95 \%$ ) data (only 7 data points, excluding 1 younger rim age) indicates a mean uncertainty of the data point common- $\mathrm{Pb}$ 
Table 9

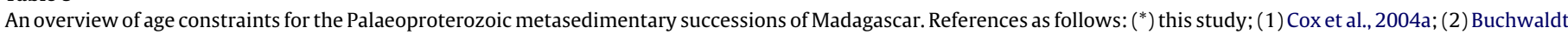

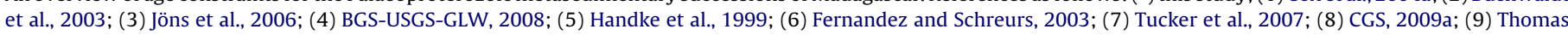
et al., 2009.

\begin{tabular}{|c|c|c|c|}
\hline & Itremo group & Sahantaha group & Maha group \\
\hline Metamorphic zircon & Ambalavao Suite $550 \mathrm{Ma}\left(1,{ }^{*}\right)$ & Maevarano Suite $520 \mathrm{Ma}(2,3)$ & Ambalavao Suite $530 \mathrm{Ma}\left(4,{ }^{*}\right)$ \\
\hline Oldest intrusive & $\begin{array}{l}\text { Imorona-ltsindro Suite } \sim 800 \mathrm{Ma}(5,6,7) \\
\text { Dabolava Suite } \sim 1000 \mathrm{Ma}(7,8)\end{array}$ & Antsirable Nord Suite $760 \mathrm{Ma}(4,9)$ & Imorona-ltsindro Suite $\sim 820 \mathrm{Ma}(4)$ \\
\hline Youngest detrital zircon & $1720 \mathrm{Ma}(1)$ & $1800 \mathrm{Ma}(4, *)$ & $1800 \mathrm{Ma}\left(4,{ }^{*}\right)$ \\
\hline Basement rocks & Antananarivo Craton $2500 \mathrm{Ma}(7,8)$ & $\begin{array}{l}\text { Antananarivo and Antongil cratons } \\
2500 \mathrm{Ma} \text { and possibly } 3200 \mathrm{Ma} \mathrm{(4)}\end{array}$ & Masora Craton 2500 and $3200 \mathrm{Ma}$ \\
\hline
\end{tabular}

corrected ${ }^{207} \mathrm{~Pb} /{ }^{206} \mathrm{~Pb}$ ages of $36 \mathrm{Ma}(2 \sigma)$ and a histogram bin width efficiency of $81.4 \%$ (at $60 \mathrm{Ma}$ bin width). The probability density distribution indicates age maxima at: 2790, 2680, 2500 and $2160 \mathrm{Ma}$ rounded to the nearest $10 \mathrm{Ma}$ (Fig. 10d). One analysis on a high uranium unzoned rim yielded a concordant ${ }^{206} \mathrm{~Pb} /{ }^{238} \mathrm{U}$ age of $552 \pm 30 \mathrm{Ma}(2 \sigma)$, recording a metamorphic overprint at that time. Due to the strongly discordant nature of these zircon analyses and the few concordant points, no proportional interpretation or constraints on depositional age can be made from these data. However, the concordant ages do still resolve source material of ca. 2790, 2680, 2500 and 2160 Ma contributing to this sample, although other potential ages of source material are not resolvable.

\section{Discussion}

\subsection{Three groups of apparent common provenance}

This study shows that lithologically similar metasedimentary rocks of the Itremo, Sahantaha and Maha groups in west-central, northern and east-central Madagascar yield common spectra of detrital zircon ages, and coeval youngest detrital grains (Table 9). Based on the youngest detrital zircon, all three groups were deposited sometime after ca. $1.8 \mathrm{Ga}$, probably during the Palaeoproterozoic. The Itremo and Sahantaha groups are mainly composed of interlayered quartzites, calc-silicates and metapelites, with a volcanic component (amphibolites) which could not be dated directly. In contrast, the Maha Group is dominated by pelitic rocks associated with quartzites, and with more common amphibolitic rocks. The sedimentary facies in each group varies from proximal shelf (quartzites with or without carbonates) to distal basinal (metapelites, possible metaturbidites). In general, the proximal facies lie adjacent to the present domain margins, suggesting that the units represent dissected remnants of former continental margin successions that were deposited no earlier than ca. 1.8 billion years ago.

\subsection{Potential source terranes}

Previous workers have suggested that the Itremo Group was originally derived from Palaeoproterozoic provenance areas in East Africa (Cox et al., 2004a; Fitzsimons and Hulscher, 2005), including the $2.0-1.8 \mathrm{Ga}$ Ubendian and Usagaran belts and the ca. $1.8 \mathrm{Ga}$ Muva Supergroup. The abundant presence of $1.8 \mathrm{Ga}$ zircon in the Sahantaha and Maha groups also matches an East African provenance model, but cannot be considered a viable option if we accept the model of a Neoproterozoic suture (the Betsimisaraka Suture), which would have separated the Sahantaha and Maha groups from East Africa during the Palaeoproterozoic

An alternative source of $1.8 \mathrm{Ga}$ zircons is provided by recent work in southern Madagascar that has identified Palaeoproterozoic rocks in the Anoysen-Androyen Domain (2.2-1.8 Ga; Tucker et al., 2010a), which is separated from the Antananarivo Craton by a major shear zone. The occurrence of Dabolava Suite intrusions in both the Antananarivo and Anoysen-Androyen Domains does indicate that the two domains were linked before $1.0 \mathrm{Ga}$ so that the Palaeoproterozoic rocks of the Anoysen-Androyen Domain could have been a proximal source for the $1.8 \mathrm{Ga}$ detrital zircons in the Itremo sediments. If this linkage occurred prior to deposition of the Itremo, Sahantaha and Maha groups, and if there is no Neoproterozoic suture in East Madagascar, then the 2.2-1.8 Ga rocks within the Anoysen-Androyen Domain could have formed a potential source for all three groups.

Another potential source area for the $1.8 \mathrm{Ga}$ detrital zircons is the Greater Dharwar Craton (Tucker et al., 2010b). This comprised present-day South India and parts of Sri Lanka and possibly either the Antananarivo, Antongil and Masora cratons, or just the Antongil and Masora cratons if the Betsimisaraka Suture exists. The $1.8 \mathrm{Ga}$ rocks identified along the northwestern margin of the Greater Dharwar Craton within the Aravalli Mobile Belt (Roy, 1988; Wiedenbeck and Goswami, 1994; Gupta et al., 1997; Singh et al., 2010; AMB on Fig. 1) could have been the missing proximal source for the Sahantaha and Maha sediments. Limited geochronological data in the Aravalli Mobile Belt indicate granitoid magmatism and felsic volcanism between 2026 and $1723 \mathrm{Ma}$ (Naha and Halyburton, 1974a,b; Choudhary et al., 1984; Naha and Mohanty, 1988; Roy, 1988; Sharma, 1988; Sarkar et al., 1989; Wiedenbeck and Goswami, 1994; Fareeduddin and Kröner, 1998; Kaur et al., 2009; Singh et al., 2010). Palaeoproterozoic mineralisation is indicated by model $\mathrm{Pb}$ ages of 1.8 and $1.7 \mathrm{Ga}$ for the Rajpura-Dariba deposits in the Bhilwara Belt and the conformable sediment-hosted sulphide ores at Sawar in the Aravalli Belt respectively (Deb et al., 1989, 2001). In addition to those possible primary source rocks, two sedimentary successions are recognised which contain carbonate (including stromatolites) and pelite, and have been metamorphosed at ca. 1.8 Ga (Deb et al., 1989; Sarkar et al., 1989; Sugden et al., 1990; Verma and Greiling, 1995).

\subsection{Were any of the groups tectonically emplaced?}

The Sahantaha Group is in tectonic contact with the AnaborianaManampotsy Belt and the Antananarivo Craton along the Sandrakota Shear Zone (SSZ, Fig. 2), and is thrust over the Antongil Craton along the Andraparaty Thrust. Nowhere in the modern literature has an unconformable contact been described between Sahantaha Group and Archaean basement, and we therefore support an allochthonous or at least parautochthonous setting for this group. The presence of major recumbent folds (nappes) defined by quartzites in the Sahantaha Group illustrates horizontal tectonic transport (BGS-USGS-GLW, 2008).

The Maha Group is mostly preserved as klippen and synformal infolds that are for the most part tectonically bounded and locally constitute thrust slices within the Masora Craton.

The base of the Itremo Group has been described both as tectonic (e.g. Collins et al., 2000a; Nédélec et al., 2003; Collins, 2006; CGS, 2009a,b) or as unconformable (Cox et al., 2004a). Despite this, there is general agreement that the group underwent extensive east-west shortening which, together with a top-to-the-east 
shear sense, led Collins et al. (2000a) to interpret the group as an east-vergent stack of thrust sheets. However, the identification of overturned Itremo Group units below Archaean rocks identical to those of the Antananarivo Craton, as well as the unconformable contacts recognised locally, show that the Itremo Group may have been originally deposited on Antananarivo Craton basement. Based on present knowledge, the Itremo Group is therefore best seen as an autochthonous, locally parautochthonous sequence.

\subsection{Minimum age of deposition}

The Itremo and Maha groups, along with the surrounding crust, are intruded by the Imorona-Itsindro Suite (840-720 Ma) and the Ambalavao Suite (ca. $550 \mathrm{Ma}$ ). The oldest intrusive in the Itremo Group is ca. $800 \mathrm{Ma}$ (Handke et al., 1999) and the oldest intrusive into the Maha Group is ca. 820 Ma (BGS-USGS-GLW, 2008), placing minimum ages on both groups (Table 9). In addition, six zircon rims on detrital zircon of one of our Itremo samples indicate the quartzite was affected by metamorphism at ca. $810 \mathrm{Ma}$, in keeping with deposition prior to that.

The Sahantaha Group was possibly intruded at ca. $750 \mathrm{Ma}$, but certainly at ca. 530 Ma by the arc-related Antsirabe-Nord and the post-collisional Maevarano suites respectively (Thomas et al., 2009). Based on this, a minimum age of deposition of 750, or $530 \mathrm{Ma}$ can be proposed.

\section{Conclusions}

Three regionally separated Palaeoproterozoic metasedimentary successions in Madagascar give similar detrital age patterns and maximum ages of deposition (ca. $1.8 \mathrm{Ga}$ ). All these sequences have been strongly affected by late Neoproterozoic-Cambrian tectonism, forming the structural contacts of the successions with the Archaean crustal units of Madagascar, locally as thrust sheets. There is no known local source for the ca. $1.8 \mathrm{Ga}$ detrital zircons that dominate the detrital zircon populations in the four samples from the Sahantaha and Maha groups. However, possible sources are recognised from the Greater Dharwar Craton, and this could support the hypothesis that the Antongil and Masora cratons were joined to the Greater Dharwar Craton prior to late Neoproterozoic-Cambrian orogenesis.

For the Itremo Groups samples there is a proximal source preserved in southern Madagascar (Tucker et al., 2010a). If all of Madagascar's Archaean domains were orginally part of the Greater Dharwar Craton, then the $1.8 \mathrm{Ga}$ detrital zircons in the Itremo Group (as well as in the Sahantaha and Maha groups) could have been sourced from the Anoysen-Androyen Domain of southern Madagascar, as well as from other sources in what are now India and Sri Lanka. The alternative suggestion that Ubendian-Usagaran rocks, in what is now east Africa, sourced the Itremo sediments remains a possibility (Cox et al., 1998, 2004a; and Fitzsimons and Hulscher, 2005).

\section{Acknowledgements}

The authors acknowledge permission to publish this article from the Executive Directors of the BGS and USGS. John Carney is thanked for an internal BGS review which materially improved the manuscript, while the authors are also grateful for comments provided by the USGS reviewers.

\section{Appendix A. Supplementary data}

Supplementary data associated with this article can be found, in the online version, at doi:10.1016/j.precamres.2011.04.004.

\section{References}

Alsac, C., 1963a. Feuille Ankotrofotsy I.49, Dabolava J.49, Anjoma - Ramartina K.49, $1 / 100000$, Service Géologique de Madagascar.

Alsac, C., 1963b. Etude géologigue et prospection des feuilles au 1:100 000: Ankotrofotsy (I-49); Dabolava (J-49); Anjoma Ramartina (K-49). Service du Bureau Géologique, Antananarivo, Madagascar, pp. 147-157.

Ashwal, L.D. (Ed.), 1997. UNESCO-IUGS-IGCP 348/368 International Field Workshop on Proterozoic Geology of Madagascar-Guidebook to Field Excursions. Gondwana Research Group Miscellaneous Publication, p. 53.

Bertucat, M., Ramarokoto, A., Rakotoarisoa, B., Rakotondratsima, J., 1958. Etude Geologique et prospection des feuilles Ambodinonoka-Vohilava (PQ52) Ampasinambo-Ambodilafa (QR51), Marolambo (R50), Service geologique.

Bésairie, H., 1959. Le socle cristallin de Madagascar. International Geological Congress, pp. 47-62.

Bésairie, H., 1964. Madagascar carte géologique. Service Géolographique a Madagascar, Tananarive.

Bésairie, H., 1969. Déscription géologique du massif ancien de Madagascar. Troisième volume: la région centrale. 1. Le Système du Graphite, Groupe d'Ambatolampy. Documentation du Bureau Géologique. Service Géologique de Madagascar, Tananarive, p. 73.

Bésairie, H., 1970. Déscription géologique du massif ancien de Madagascar. Quatrième volume: la région centrale. 2. Le Système du Vohibory, Série schisto-quartzo-calcaire, Groupe d'Amborompotsy. Documentation du Bureau Géologique. Service Géologique de Madagascar, Tananarive, 177d, 86.

BGS-USGS-GLW, 2008. Revision de la cartographie géologique et minière des zones Nord et Centre de Madagascar (Zones A, B et D). R.M. Key, Pitfield, P.E.J., Thomas, R.J., Annels, R.A., Bauer, W., Burton, B., Conrad, J., Chacksfield, B., De Waele, B., Ford, J., Goodenough, K.M., Hall, M., Hawkins, M., Horstwood, M., Howard, K., Jordan, C., Kusky, T., Lapworth, D., Lidke, D., Peters, S.G., Pouliquen, G., Rakotoson, R.L., Ralison, V., Randriamananajara, T., Scheib, A., Schofield, D.I., Smith, R.A., Styles, M., Taylor, C.D., Tucker, R.D., British Geological Survey Research Report. Republique de Madagascar Ministère de L'energie et des Mines (MEM/SG/DG/UCP/PGRM), p. 1049.

Bousteyak, L., 1970. Stratigraphie des migmatites dans la région d'Anjozorobe. Comité National Malgache de Géologie, Tananarive.

Bousteyak, L., Rakotonanahary, Rakotomandimby, Rakotoarivelo, G., Randrianasolo, L. and Raveloson, A., 1970-72. Carte géologique de Anjialavabe - Doany (VW35). Service géologique de Madagascar, Antananarivo.

Bousteyak, L., 1972. Etude geologique et prospection des feuilles Andapa, Maromimbihy (WXY.36) au 1/100.000, completage des feuilles Doany, Anjialavabe (VW.35) et Ambodisatrana (V.36), Rapport Annuel du Service Géologique, 1972, $1-18$.

Bousteyak, L., 1974. Etude Geologique et prospection de la feuille au 1/100.000 Doany W.35, Rapport Annuel du Service Géologique, 1971, 1-18.

Brenon, P., 1951. Carte géologique de Andravory - Sambava (VW 34-35, XY 34-35). $1: 100,000$, Service Géologique.

Buchwaldt, R., Tucker, R.D., 2001. P-T-time constraints on the metamorphic rocks of North Madagascar and their relevance on the assembly of Gondwanaland. In: Anonymous (Ed.), Geological Society of America, 2001 annual meeting. Geological Society of America (GSA). Boulder, CO, United States, p. 436.

Buchwaldt, R., Tucker, R.D., Dymek, R.F., 2002. Petrogenetic implication of three contrasting terranes in northern Madagascar, Geological Society of America, 2002 Annual meeting. Geological Society of America (GSA), Denver, CO, United States, p. 448.

Buchwaldt, R., Tucker, R.D., Dymek, R.F., 2003. Geothermobarometry and U-Pb Geochronology of metapelitic granulites and pelitic migmatites from the Lokoho region, Northern Madagascar. American Mineralogist 88, 1753-1768.

Buchwaldt, R., 2006. Geology of the Neoproterozoic and Cenozoic rocks of North Madagascar, Ph. D. Dissertation. Washington University, St. Louis, Missouri (USA), p. 397.

CGS, 2009a. Map Explanation of 1:100 000 scale (Zone E) Sheets I46 - Ambararata, J46 - Beopoaka, I47 - Itondy, J47 - Belobaka, K47 - Ambatofotsy, I48 - Miandrivazo, J48 - Betrondro, K48 - Ambatondradama, I49 - Ankotrofotsy, J49 Dabolava, K49 - Anjoma-Ramartina, L49 - Vasiana, M49 - Ankazomiriotra, N49 - Antsirabe. P.H. Macey, Miller, J.A., Armstrong, R.A., Bisnath, A., Yibas, B., Frost-Killian, S., Chevallier, L., Mukosi, N.C., Cole, J., le Roux, P. and Haddon, I.G. Ministère de L'Energie et des Mines - Project de Gouvernance des Ressources Minérales, Antananarivo, Madagascar and Council for Geoscience, Pretoria, South Africa.

CGS, 2009b. Map Explanation of 1:100 000 scale sheets (Zone F) G41 - Ambohipaky, H41 - Bevary, G42 - Mangoboky, H42 - Bekodoka, G43 - Andolamasa, H43 - Andrafialava and parts of G40 - Ankasakasa, F40 - Saint-Andre, F41 - Betsalampy, H40 - Maroboaly-Sud, I40 - Soalala-Sud, I41 - Andranomavo, F42 - Marovoay Kely, I42 - Mahabe, F43 - Bebao, F44 - Antranogoaika, G44 Morafeno, I43 - Ampoza, H44- Bemolanga and I44 Makaraingo. P.H. Macey, Miller, J.A., Armstrong, R.A., Ingram, B.A., Bisnath, A., Yibas, B., Frost-Killian, S., Chevallier, L., Finkelstein, J. and Haddon, I.G. Ministère de L'Energie et des Mines - Project de Gouvernance des Ressources Minérales, Antananarivo, Madagascar and Council for Geoscience, Pretoria, South Africa.

Choudhary, A.K., Gopalan, K., Sastry, C.A., 1984. Present status of the geochronology of the Precambrian rocks of Rajasthan. Tectonophysics 105, 131-140.

Collins, A.S., Kröner, A., Razakamanana, T., Windley, B.F., 2000a. The Tectonic architecture of the East African Orogen in Central Madagascar - a structural and geochronological perspective. Journal of African Earth Sciences 30, 21. 
Collins, A.S., Kröner, A., Razakamanana, T., Windley, B.F., 2000b. The tectonic architecture of central Madagascar; disentangling the amalgamation Gondwana. In: Skilbeck, C.G., Hubble Thomas, C.T. (Eds.), Understanding Planet Earth; Searching for a Sustainable Future; on the Starting Blocks of the Third milLennium; Abstracts. Geological Society of Australia, Sydney, N.S.W., Australia, p. 2000.

Collins, A.S., Fitzsimons, I.C.W., Hulscher, B., Razakamanana, T., 2003a. Structure of the eastern margin of the East African Orogen in central Madagascar. Precambrian Research 123 (2-4), 111-133.

Collins, A.S., Johnson, S., Fitzsimons, I.C.W., Powell, C.M., Hulscher, B., Abello, J., Razakamanana, T., 2003b. A structural section through the East African belt in central Madagascar, Proterozoic East Gondwana: Supercontinent Assembly, Breakup. In: Yoshida, M., Windley, B.F., Dasgupta, S. (Eds.), Proterozoic East Gondwana: Supercontinent Assembly and Breakup. Geological Society, London, pp. 363-379, Special Publication 206.

Collins, A.S., Kröner, A., Fitzsimons, I.C.W., Razakamanana, T., 2003c. Detrital Footprint of the Mozambique Ocean: U/Pb SHRIMP and Pb Evaporation Zircon Geochronology of Metasedimentary Gneisses in Eastern Madagascar. Tectonophysics 375, 77-99.

Collins, A.S., Pisarevsky, S.A., 2005. Neoproterozoic/Cambrian incorporation of India into Gondwana: the evolution of the circum-Indian Orogens. International Geology Review 71, 229-270.

Collins, A.S., 2006. Madagascar and the amalgamation of Central Gondwana. Gondwana Research 9, 3-16.

Cox, R., Armstrong, R.A., Ashwal, L.D., Wit, M.J.D., 1995. Sedimentology, tectonics and geochronology of Proterozoic shelf sediments of the Itremo Group, central Madagascar: implications for the assembly of East Gondwana. Geological Society of America, Abstracts with Programs, 27: A-161.

Cox, R.M., Armstrong, R.A., Ashwal, L.D., Raoelison, I.L., 1996. The geology of the Itremo Group central Madagascar; deformed remnant of a Proterozoic continental shelf sequence. In: Santosh, M., Yoshida, M. (Eds.), Proceedings of the UNESCO-IUGS-IGCP-368 International Field Workshop on the Proterozoic Continental Crust of Southern India. Gondwana Research Group Miscellaneous Publication. Osaka City University, Department of Geosciences, Faculty of Science, Gondwana Research Group, Osaka, Japan, pp. 86-87.

Cox, R., Armstrong, R.A., 1997. Geochronology and provenance of the Itremo Group, central Madgascar. In: Cox, R., Ashwal Lewis, D. (Eds.), Proceedings of the UNESCO-IUGS-IGCP-348/368 international symposium and field workshop on Proterozoic geology of Madagascar; abstract volume. Gondwana Research Group Miscellaneous Publication. Osaka City University, Department of Geosciences, Faculty of Science, Gondwana Research Group, Osaka, Japan, pp. 13-14.

Cox, R., Armstrong, R.A., Ashwal, L.D., 1998. Sedimentology, geochronology and provenance of the Proterozoic Itremo Group, central Madagascar and implications for pre Gondwana palaeogeography. Journal of the Geological Society 155, 1009-1024

Cox, R., Coleman, D.S., Wooden, J.L., Chokel, C.B., 2000. SHRIMP data from detrital zircons with metamorphic overgrowths reveal tectonic history of the Proterozoic Itremo Group, central Madagascar. In: Anonymous (Editor), Geological Society of America, 2000 annual meeting. Geological Society of America (GSA). Boulder, CO, United States, 2000

Cox, R., Coleman, D.S., Wooden, J.L., DeOreo, S.B., 2001. A newly recognised Late Neoproterozoic metasedimentary sequence in Central Madagascar suggests terrane juxtaposition at $560 \pm 7$ Ma during Gondwana assembly. Geological Society of America Abstracts with Programs, 33: A436.

Cox, R., Coleman, D.S., Raharimahefa, T., Chokel, C.B., Wooden, J.L., White, L.D., 2003. Mesoproterozoic Madagascar-Africa Connection Based on SHRIMP U-Pb Ages of Detrital Zircons from the Itremo Group and Sahantaha Series in Central and Northern Madagascar. Annual meeting Geological Society of America, Seattle, p. 302.

Cox, R., Coleman, D.S., Chokel, C.B., DeOreo, S.B., Wooden, J.L., Collins, A.S., De Waele, B., Kröner, A., 2004a. Proterozoic tectonostratigraphy and paleogeography of central Madagascar derived from detrital zircon $\mathrm{U}-\mathrm{Pb}$ age populations. Journal of Geology 112, 379-399.

Cox, R., Fernandez, A., Schreurs, G., 2004b. Discussion on tectonic evolution of the Proterozoic Itremo Group metasediments in Central Madagascar. Journal of the Geological Society, London 161, 539-541.

de la Roche, H., 1951. Carte géologique d'Ifanadiana - Mananjary (PQRS52-53). 1:200,000 (Antananarivo: Bureau géologique.).

de la Roche, H., 1953. Étude géologique de la region aurifère de Mananjary. Travaux du Bureau Géologique, Madagascar 49, 94.

Deb, M., Thorpe, R.I., Cumming, G.L., Wagner, P.A., 1989. Age, Source and Stratigraphic Implication of Pb Isotope Data for Conformable, Sediment-hosted, Base Metal Deposits in the Proterozoic Aravalli-Delhi Orogenic Belt, Northwestern India. Precambrian Research 43, 1-22.

Deb, M., Thorpe, R.I., Krstic, D., Corfu, F., Davis, D.W., 2001. Zircon U-Pb and galena $\mathrm{Pb}$ isotope evidence for an approximate $1.0 \mathrm{Ga}$ terrane constituting the western margin of the Aravalli-Delhi orogenic belt, northwestern India. Precambrian Research 108, 195-213.

De Waele, B., Horstwood, M.S.A., Bauer, W., Key, R.M., Pitfield, P.E.J., Potter, C.J., Rabarimana, M., Rafahatelo, J.M., Ralison, V., Randriamananjara, T., Smith, R.A., Thomas, R.J., Tucker, R.D., 2008. U-Pb Detrital Zircon Geochronological Provenance Patterns of Supracrustal Successions in Central and Northern Madagascar. Colloquium of African Geology, Hammamat, Tunisia, p. 3.

Dormois, R., 1949. Etude Géologique des feuilles Andavakoera et Vohemar. Rapport Annuel du Service Géologique 1948, 19-28.

Emberger, A., 1955. Les terrains cristallins du pays Betsileo et de ses confins orientaux. Thèse d'Etat Thesis, Université Clermont II, Clermont-Ferrand, France.
Fareeduddin, Kröner, A., 1998. Single zircon age constraints on the evolution of Rajasthan granulite. In: P.B.S. (Ed.), The Indian Precambrian. Scientific Publishers (India), Jodhpur, pp. 547-556.

Fernandez, A., Huber, S., Schreurs, G., Villa, I., Rakotondrazafy, M., 2001. Tectonic evolution of the Itremo Region (Central Madagascar) and implications for Gondwana assembly. Gondwana Research 4 (2), 165-168.

Fernandez, A., Schreurs, G., 2003. Tectonic evolution of the Proterozoic Itremo Group metasediments in central Madagascar. In: Yoshida, M., Windley, B., Dasgupta, S. (Eds.), Proterozoic East Gondwana: Supercontinent Assembly and Breakup. Special Publication of the Geological Society, London, pp. 381-399.

Fernandez, A., Schreurs, G., Villa, I.M., Huber, S., Rakotondrazafy, M., 2003. Age constraints on the tectonic evolution of the Itremo region in Central Madagascar. Precambrian Research 123 (2-4), 87-110.

Fitzsimons, I.C.W., Hulscher, B., 2005. Out of Africa: detrital zircon provenance of central Madagascar and Neoproterozoic terrane transfer across the Mozambique Ocean. Terra Nova 17, 224-235.

Fournié, L., Heurtebize, G., 1963. Géologie de la région IkalamavonyAmpandramaika-Bekisopa, centre sud de Madagascar. Comité National Malgache de Géologie, Tananarive.

GAF-AG-BGR, 2009. Explanatory notes for the Ikalamavony-Itremo Domain, Centra Madagascar. Réalisation des travaux de cartographie géologique de Madagascar, Révision approfondie de la cartographie géologique et minière aux échelles $1 / 100000$ et $1 / 500.000$ zone Sud. (CARTOSUD). Project de Gouvernance des Ressources Minérales, Contrat No 169/05 DP/MEM/SG/DG/UCP/PGRM, Antananarivo, p. 105.

Goodenough, K.M., Thomas, R.J., De Waele, B., Key, R.M., Schofield, D.I., Bauer, W., Tucker, R., Rafahatelo, J.M., Rabarimanana, M., Ralison, A.V., Randriamananjara, T., 2010. Post-collisional magmatism in the central East African Orogen: the Maevarano Suite of north Madagascar. Lithos 116, 18-34.

Goncalves, P., Nicollet, C., Lardeaux, J.M., 2003. Finite Strain Pattern in Andriamena unit (North-Central Madagascar): evidence for Late Neoproterozoic-Cambrian Thrusting during Continental Convergence. Precambrian Research 123 135-157.

Goncalves, P., Nicollet, C., Montel, J.M., 2004. Petrology and in-situ U-Th-Pb monazite geochronology of ultra-high temperature metamorphism from the Andriamena mafic unit, north-central Madagascar. Significance of a petrographical PT path in a polymetamorphic context. Journal of Petrology 10, 19231957.

Gupta, S.N, Arora, Y.K., Mathur, R.K., Iqbaluddin, Prasad, B., Sahai, T.N., Sharma, S.B. 1997. The Precambrian geology of the Aravalli region, southern Rajasthan and northeastern Gujarat. Memoirs of the Geological Survey of India 123, 262.

Handke, M.J., Tucker, R.D., Hamilton, M.A., 1997a. Age, geochemistry, and petrogenesis of the early Neoproterozoic $(800-790 \mathrm{Ma})$ intrusive igneous rocks of the Itremo region, central Madagascar. In: Cox, R., Ashwal Lewis, D. (eds.), Proceedings of the UNESCO-IUGS-IGCP-348/368 international symposium and field workshop on Proterozoic geology of Madagascar; abstract volume. Gondwana Research Group Miscellaneous Publication 5, pp. 28-29.

Handke, M.J., Tucker, R.D., Hamilton, M.A., 1997b. Early Neoproterozoic (800-790 Ma) intrusive igneous rocks in central Madagascar; geochemistry and petrogenesis. In: Anonymous (Editor), Geological Society of America, 1997 Annual meeting. Abstracts with Programs - Geological Society of America (GSA), Boulder, CO, United States, p. 468

Handke, M.J., Tucker, R.D., Ashwal, L.D., 1999. Neoproterozoic continental arc magmatism in west-central Madagascar. Geology 27 (4), 351-354.

Hottin, G., 1976. Présentation et essai d'interprétation du Précambrien de Madagascar. Bulletin BRGM Sér. 2 Sect. 4 (2), 117-153.

Huber, S., 2000. Geologie und Geochronologie der Itremo Sedimente im Gebiet des Mont Ibity (Zentral Madagaskar). MSc Thesis, Universität Bern, Bern, Switzerland, p. 97.

Inzana, J., Kusky, T., Higgs, G., Tucker, R., 2003. Supervised classifications of Landsat TM band ratio images and Landsat TM band ratio image with radar for geological interpretations of central Madagascar. Journal of African Earth Sciences 37 (1-2) 59-72.

Jöns, N., Schenk, V., Appel, P., Razakamanana, T., 2005a. Two-stage metamorphic evolution of the Bemarivo Belt (northern Madagascar): constraints from reaction textures and in situ monazite dating, European Geosciences Union 2005 Geophysical Research Abstracts 7, Graz, p. 2.

Jöns, N., Schenk, V., Appel, P., Razakamanana, T., 2005b. P-T evolution of the Bemarivo Belt (northern Madagascar): the final assembly of Gondwana. In: Wingate M.T.D., Pisarevsky, S.A. (Editors), Supercontinents and Earth Evolution, Geological Society of Australia, Abstracts, vol. 81, p. 103, Fremantle.

Jöns, N., Schenk, V., Appel, P., Razakamanana, T., 2006. Two-stage metamorphic evolution of the Bemarivo Belt of northern Madagascar: constraints from reaction textures and in situ monazite dating. Journal of Metamorphic Geology 24 329-347.

Joo, J., 1963. Feuille Ambararata I.46, Bepoaka J.46, 1/100 000, Service Géologique de Madagascar.

Jourde, G., Razanakolona, J., Rasamoelina, D., Raveloson, S.A., 1978. Carte géologique de Betsiaka-Antanamboa-Ampisikinana (VWX-32). Service géologique de Madagascar, Antananarivo.

Kaur, P., Chaudhri, N., Raczek, I., Kroner, A., Hofmann, A.W., 2009. Record of 1.82 Ga Andean-type continental arc magmatism in NE Rajasthan, India: insights from zircon and Sm-Nd ages, combined with $\mathrm{Nd}-\mathrm{Sr}$ isotope geochemistry. Gondwana Research 16, 56-71.

Kröner, A., Windley, B.F., Jaeckel, P., Brewer, T.S., Razakamanana, T., 1999a. Precambrian granites, gneisses and granulites from Madagascar: new zircon ages and 
regional significance for the evolution of the Pan-African orogen. Journal of the Geological Society, London 156, 1125-1135.

Kröner, A., Windley, B.F., Jaeckel, P., Collins, A.S., Brewer, T.S., Nemchin, A., Razakamanana, T., 1999b. New zircon ages for Precambrian granites, gneisses and granulites from central and southern Madagascar: Significance for correlations in East Gondwana. Gondwana Research 2 (3), 351-352.

Kröner, A., Hegner, E., Collins, A.S., Windley, B.F., Brewer, T.S., Razakamanana, T., Pidgeon, R.T., 2000. Age and magmatic history of the Antananarivo Block, central Madagascar, as derived from zircon geochronology and Nd isotopic systematics. American Journal of Science 300 (4), 251-288.

Kröner, A., 2001. The Mozambique belt of East Africa and Madagascar: significance of zircon and Nd model ages for Rodinia and Gondwana supercontinent formation and dispersal (Du Toit Memorial Lecture 1999). South African Journal of Geology 104 (2), 151-166.

Ludwig, K.R., 2003. Isoplot/Ex Version 3.00: A Geochronological Toolkit for Microsoft Excel. Berkeley Geochronology Center, Berkeley, CA.

Meert, J.G., Nédélec, A., Hall, C., Wingate, M.T.D., Rakotondrazafy, M., 2001. Paleomagnetism, geochronology and tectonic implications of the Cambrian-age Carion Granite, central Madagascar. Tectonophysics 340, 1-21.

Meert, J.G., Nédélec, A., Hall, C., 2003. The stratoid granites of central Madagascar: paleomagnetism and further age constraints on Neoproterozoic deformation. Precambrian Research 120 (1-2), 101-129.

Moine, B., 1963. Feuille Miandrivazo I.48, Betrondro J.48, Ambatondradama K.48, 1/100 000, Service Géologique de Madagascar.

Moine, B., 1966. Grands traits structuraux du massif schisto-quartzo-calcaire (centre ouest de Madagascar). Compte Rendus Semaine Géologique Madagascar, 93-97.

Moine, B., 1967a. Relations stratigraphiques entre la série < schisto-quartzo-calcaire $>$ et les gneiss environnants (centre ouest de Madagascar). Compte Rendus Semaine Géologique Madagascar, 49-53.

Moine, B., 1967b. Etudes complémentaires dans le massif "schisto-quartzo-calcaire" (région d'Ambatofinandrahana). Rapport Annuel du Service Géologique de Madagascar, 69-82.

Moine, B., 1968a. Relations stratigraphiques entre la série «Schisto-QuartzoCalcaire» et les gneiss environnants (centre ouest de Madagascar): donées d'une première étude géochimique. Comptes Rendus de la Semaine Géologique 1967 $49-53$.

Moine, B. 1968b. Carte Géologique à 1/200,000 du massif schisto-quartzodolomitique, region d'Ambatofinandrahana, centre-ouest du socle cristallin du Précambrien de Madagascar. Centre de l'Institut Geographique National a Tanananarive (imprimeur), Sciences de la Terre, Nancy (éditeur).

Moine, B., 1974. Caractères de sédimentation et de métamorphisme des séries précambriennes épizonales à catazonales du centre de Madagascar (Région d'Ambatofinandrahana). Sciences de la Terre, Mémoire, Nancy, p. 293.

Naha, K., Halyburton, R.V., 1974a. Early Precambrian stratigraphy of central and southern Rajasthan, India. Precambrian Research 1, 55-73.

Naha, K., Halyburton, R.V., 1974b. Late stress systems deduced from conjugate folds and kink bands in the "Main Raialo Syncline" Udaipur district, Rajasthan India. Bulletin Geological Society of America 85, 251-256.

Naha, K., Mohanty, S., 1988. Response of basement and cover rocks to multiple deformations a study from the Precambrian of central Rajasthan, western India. Precambrian Research 42, 77-96.

Nédélec, A., Bouchez, J.L., Grégoire, V., 2003. Quartz fabric evidence for early PanAfrican penetrative east-directed shearing in the Itremo Supracrustal Group of central Madagascar. Terra Nova 15, 20-28.

Nicollet, C., 1990. Crustal evolution of the granulites of Madagascar. In: Vielzeuf, D. Vidal, P. (Eds.), Granulites and Crustal Evolution. Kluwer Academic Publishers, Dordrecht, pp. 291-310.

Paquette, J.L., Nédélec, A., 1998. A new insight into Pan-African tectonics in the EastWest Gondwana collision zone by U-Pb zircon dating of granites from central Madagascar. Earth and Planetary Science Letters 155, 45-56.

Paquette, J.L., Moine, B., Rakotondrazafy, M.A.F., 2003. ID-TIMS using the step-wise dissolution technique versus ion microprobe $\mathrm{U}-\mathrm{Pb}$ dating of metamict Archean zircons from NE Madagascar. Precambrian Research 121 (1-2), 73-84.
Raharimahefa, T., Kusky, T.M., 2009. Structural and remote sensing analysis of the Betsimisaraka Suture in northeastern Madagascar. Gondwana Research 15, 14-27.

Rakotoarimanana, R.H., 2001. Geology and Petrology of the Dabolava Region, WestCentral Madagascar with Emphasis on Granite-Hosted Gold Mineralization. University of Witswatersrand, Johannesburg, p. 89.

Raoelison, I.L., 1997. Structure and Metamorphism of the Itremo Group, central Madagascar. MSc Thesis, Rand Afrikaans University, Johannesburg.

Roy, A.B., 1988. Stratigraphic and tectonic framework of the Aravalli Mountain Range. In: Roy, A.B. (ed.), Memoir of Geological Society of India (Precambrian of the Aravalli Mountain, Rajasthan, India), pp. 33-75.

Sarkar, G., Burman, T.R., Corfu, F., 1989. Timing of continental arc-type magmatism in northwest India: evidence from U-Pb zircon geochronology. Journal of Geology 97, 607-612.

Schofield, D.I., Thomas, R.J., Goodenough, K.M., De Waele, B., Pitfield, P.E.J., Key, R.M., Bauer, W., Walsh, G., Lidke, D., Ralison, A.V., Rabarimanana, M., Rafahatelo, J.M., Randriamananjara, T., 2010. Geological evolution of the Antongil Craton, NE Madagascar. Precambrian Research 182, 187-203.

Sharma, R.S., 1988. Pattern of metamorphism in the Precambrian Rocks of the Aravalli Mountain Belt. Memoir of Geological Society of India (Precambrian of the Aravalli Mountain, Rajasthan India) 7, 33-75.

Singh, Y.K., De Waele, B., Karmakar, S., Sarkar, S., Biswal, T.K., 2010. Tectonic setting of the Balaram-Kui-Surpagla-Kengora granulites of the South Delhi Terrane of the Aravalli Mobile Belt, NW India and its implication on correlation with the East African Orogen in the Gondwana assembly. Precambrian Research 183 , 669-688.

Sircombe, K.N., 2004. Age Display: an EXCEL workbook to evaluate and display univariate geochronological data using binned frequency histograms and probability density distributions. Computers and Geoscience 30, 21-31.

Stacey, J.S., Kramers, J.D., 1975. Approximation of terrestrial lead isotope evolution by a two-stage model. Earth and Planetary Science Letters 26, 207-221.

Sugden, T.J., Deb, M., Windley, B.F., 1990. The tectonic setting of mineralisation in the Proterozoic Aravalli - Delhi orogenic belt, NW India. In: Naqvi, S.M. (Ed.), Precambrian Continental Crust and Its Economic Resources. Elsevier, New York, pp. 367-390.

Thomas, R.J., De Waele, B., Schofield, D.I., Goodenough, K.M., Horstwood, M.S.A. Tucker, R., Bauer, W., Annels, A.E., Howard, K., Walsh, G., Rabarimana, M., Rafahatelo, J.M., Ralison, A.V., Randriamananjara, T., 2009. Geological Evolution of the Neoproterozoic Bemarivo Belt, northern Madagascar. Precambrian Research $172,279-300$.

Tucker, R.D., Ashwal, L.D., Handke, M.J., Hamilton, M.A., Le Grange, M., Rambeloson, R.A., 1999. U-Pb geochronology and isotope geochemistry of the Archean and proterozoic rocks of north-central Madagascar. Journal of Geology 107 (2) $135-153$.

Tucker, R.D., Kusky, T.M., Buchwaldt, R., Handke, M.J., 2007. Neoproterozoic nappes and superposed folding of the Itremo Group, west-central Madagascar. Gondwana Research 12 (4), 356-379.

Tucker, R.D., Roig, J.Y., Macey, P.H., Delor, C., Amelin, Y., Armstrong, R.A., Rabarimanana, M., Ralison, A.V., 2010a. A new geological framework for south-centra Madagascar and the "out-of-Africa" hypothesis. Precambrian Research 185 109-130.

Tucker, R.D., Roig, J.Y., Delor, C., Amelin, Y., Goncalves, P., Rabarimanana, M.H., Ralison, A.V., Belcher, R.W., 2010b. Neoproterozoic Extension in the Greater Dharwar Craton: a reevaluation of the "Betsimisaraka Suture" in Madagascar. Canadian Journal of Earth Science 48, 389-417.

Verma, P.K., Greiling, R.O., 1995. Tectonic evolution of the Aravalli orogen (NW India): an inverted proterozoic rift basin? Geologische Rundschau 84 683-686.

Wiedenbeck, M., Goswami, J.N., 1994. High precision $207 \mathrm{~Pb} / 206 \mathrm{~Pb}$ zircon geochronology using a small ion microprobe. Geochimica Et Cosmochimica Acta $58,2135-2141$

Windley, B.F., Razafiniparany, A., Razakamanana, T., Ackermand, D., 1994. Tectonic framework of the Precambrian of Madagascar and its Gondwana connections a review and reappraisal. Geologische Rundschau 83, 642-659. 